San Jose State University

SJSU ScholarWorks

Master's Theses

Master's Theses and Graduate Research

Fall 2018

\title{
Assessment of Peregrine Falcon (Falco peregrinus anatum) \\ Nesting Habitat in the San Francisco Bay Area
}

Prabha Venu

San Jose State University

Follow this and additional works at: https://scholarworks.sjsu.edu/etd_theses

\section{Recommended Citation}

Venu, Prabha, "Assessment of Peregrine Falcon (Falco peregrinus anatum) Nesting Habitat in the San Francisco Bay Area" (2018). Master's Theses. 4989.

DOI: https://doi.org/10.31979/etd.64d6-6c69

https://scholarworks.sjsu.edu/etd_theses/4989

This Thesis is brought to you for free and open access by the Master's Theses and Graduate Research at SJSU ScholarWorks. It has been accepted for inclusion in Master's Theses by an authorized administrator of SJSU ScholarWorks. For more information, please contact scholarworks@sjsu.edu. 
ASSESSMENT OF PEREGRINE FALCON (Falco peregrinus anatum)

NESTING HABITAT IN THE SAN FRANCISCO BAY AREA

\author{
A Thesis \\ Presented to \\ The Faculty of the Department of Environmental Studies \\ San José State University \\ In Partial Fulfillment \\ of the Requirements for the Degree \\ Master of Science
}

by

Prabha Venu

December 2018 
(C) 2018

Prabha Venu

\section{ALL RIGHTS RESERVED}


The Designated Thesis Committee Approves the Thesis Titled

ASSESSMENT OF PEREGRINE FALCON (Falco peregrinus anatum) NESTING HABITAT IN THE SAN FRANCISCO BAY AREA

by

Prabha Venu

APPROVED FOR THE DEPARTMENT OF ENVIRONMENTAL STUDIES

SAN JOSÉ STATE UNIVERSITY

December 2018

Lynne Trulio, Ph.D.

Department of Environmental Studies

William Russell, Ph.D.

Department of Environmental Studies

Douglas A. Bell, Ph.D.

East Bay Regional Park District

Richard M. Kos, AICP.

Department of Urban and Regional

Planning 


\section{ABSTRACT \\ ASSESSMENT OF PEREGRINE FALCON (Falco peregrinus anatum) NESTING HABITAT IN THE SAN FRANCISCO BAY AREA \\ by Prabha Venu}

Human encroachment into natural environments fragments and degrades the habitat for many species and raptors such as the peregrine falcon (Falco peregrinus) have adapted to the urban environment, co-existing with humans and other wildlife. The habitat preference of the American peregrine falcon subpopulation, F. p. anatum was investigated in the densely urbanized San Francisco Bay Area. In this research, Geographic Information Systems (GIS) applications to evaluate ten environmental attributes and their influence on 47 nesting sites were used. Distances from peregrine falcon nesting sites to two federally listed prey species the California least tern (Sterna antillarum browni) and the western snowy plover (Charadrius nivosus nivosus), respectively, were measured. Analysis of average nearest neighbor distance showed that the spatial distribution of nesting sites was not clustered, but more random $(z=-1.56, p=$ 0.120 ) indicating that the species was occupying any available territories as they found them. Distance to the two federally listed species differed between the 20-natural and 27anthropogenic peregrine falcon nest sites (natural $=35.37 \mathrm{~km}$, anthropogenic $=16.30 \mathrm{~km}$, $p=0.001)$. Analysis revealed the following environmental attributes, elevation, wind, precipitation, and solar radiation, to be of primary importance to the peregrine falcon breeding habitat. These results can be used by managers to assess where peregrine falcons are able to nest and may serve as inputs to a predictive model to forecast potential future nest sites. 


\section{DEDICATION}

I dedicate this research in honor of my dear father, Aravamudham Venu, who set an incredible example of a life of hard work, determination and perseverance. He soars above like a beautiful falcon catching the wind beneath its wings.

August 1, 1933 - June 23, 2015

I sincerely appreciate the tremendous support and help provided by the following people without whom this thesis would not have been brought to fruition: Dr. Lynne Trulio, who took me under her wing and provided such unwavering support for my thesis work and approach; Richard Kos, an outstanding professor and my committee advisor whose help I sought at every step of the way; Dr. Doug Bell for his invaluable feedback and guidance; Ana Rivera, a dear friend for her in-depth knowledge of GIS, insight and direction; Ms. Julie Phillips, a phenomenal human being and environmental steward who planted those seeds early on for me to follow through. Finally, I wish to thank my sweet daughter, Sahana Venu-Solbeck for her patience through our several walks to the university, library, and prolonged days and weekends at the lab.

I also want to thank the Urban and Regional Planning (URBP) Department in San José State University for adopting me as an honorary member in their department and providing me a second home as I worked on my thesis. 


\section{TABLE OF CONTENTS}

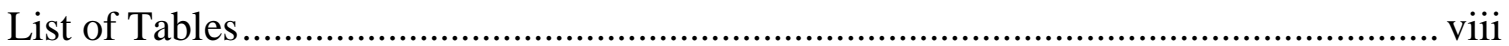

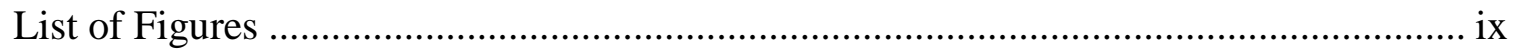

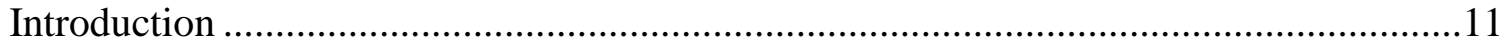

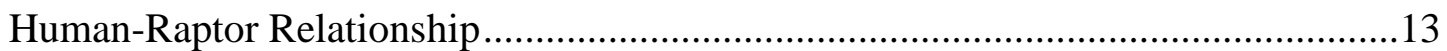

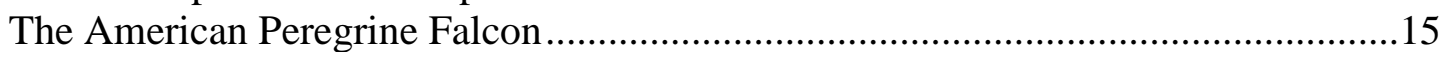

Pesticide use and post-recovery. ................................................................18

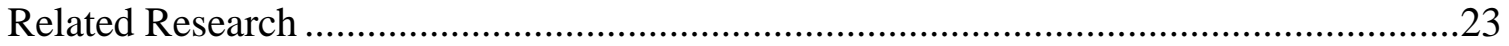

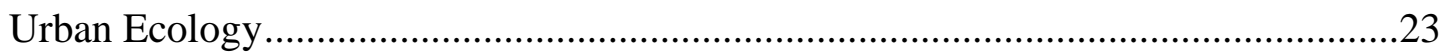

The Urban Peregrine Falcon...............................................................................26

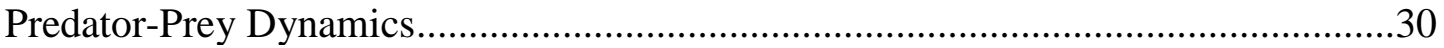

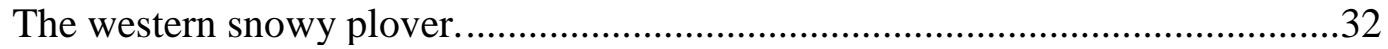

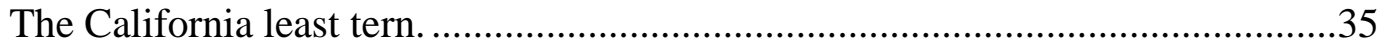

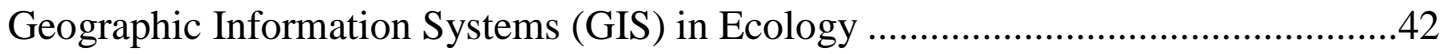

Similar Research Methods.........................................................................................43

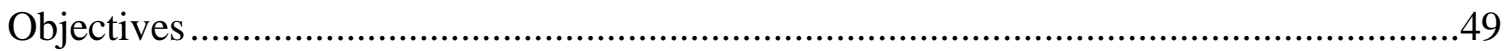

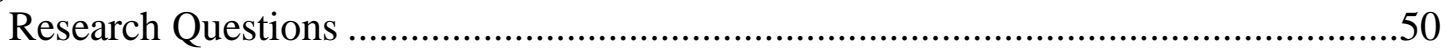

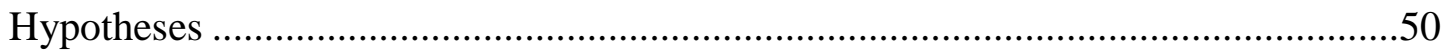

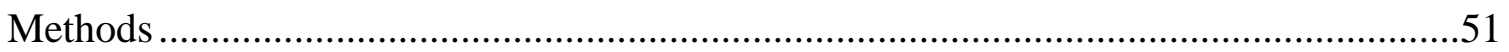

Study Area

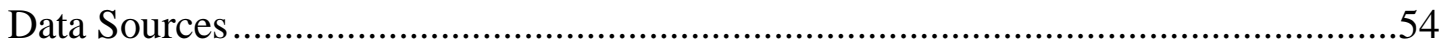

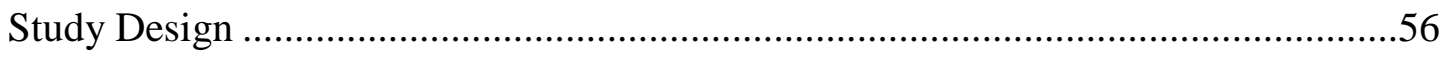

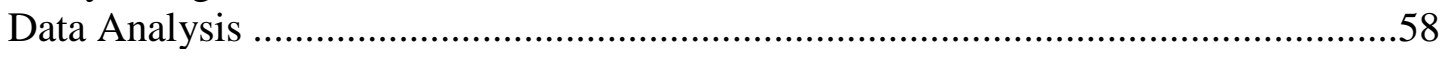

Mapping nest locations and related buffers....................................................59

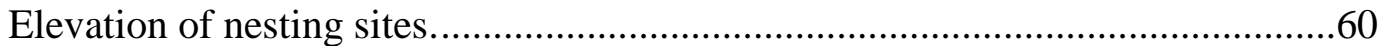

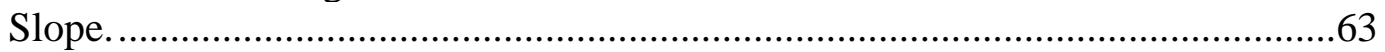

Average wind speed. ............................................................................65

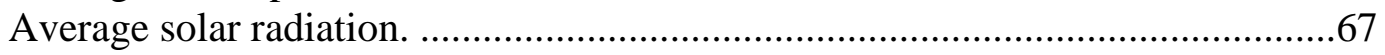

Nearest Neighbor Distance (NND) between nest sites. .....................................69

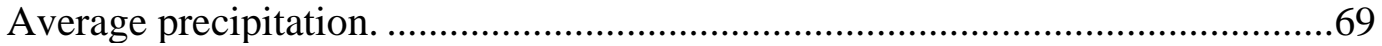

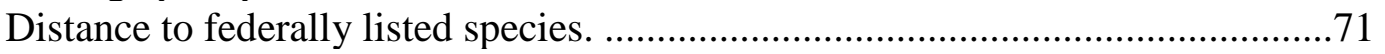

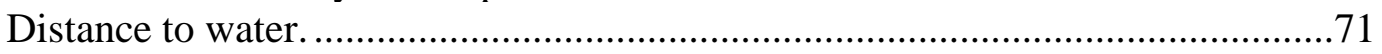

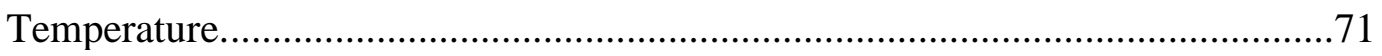

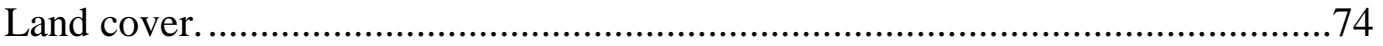




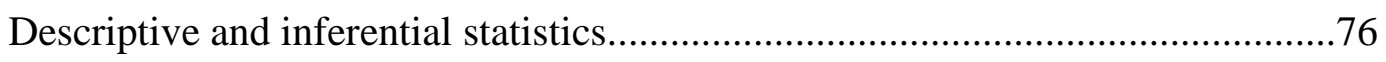

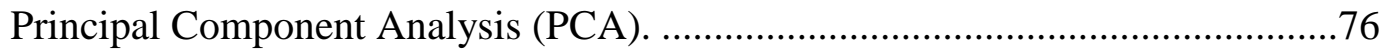

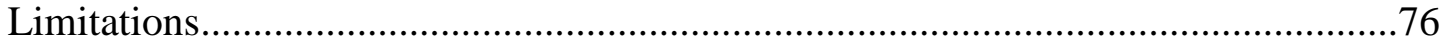

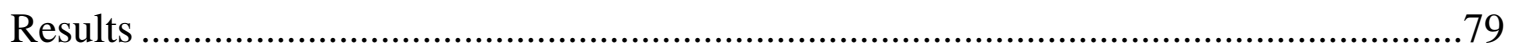

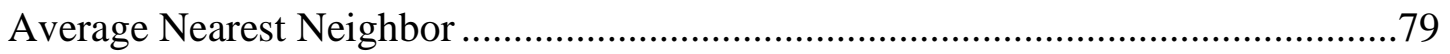

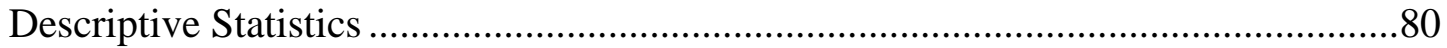

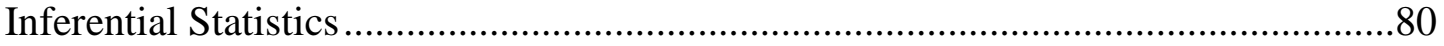

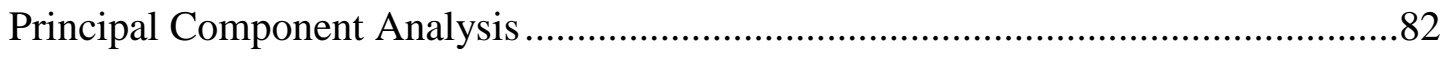

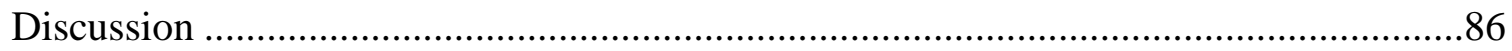

Recommendations for Management and Future Research...........................................93

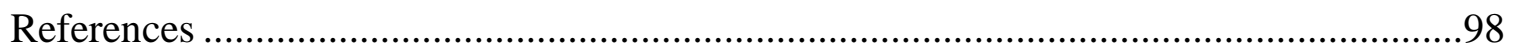

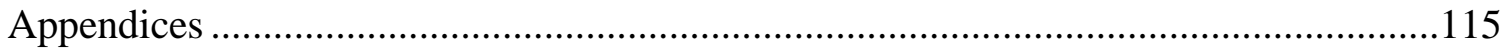

Appendix A: Descriptive Statistics - Histograms ...............................................115

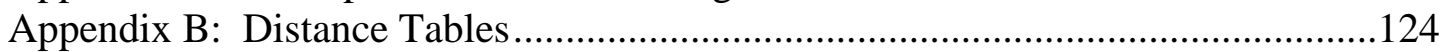

Appendix C: Descriptive and Inferential Statistics Data.......................................130

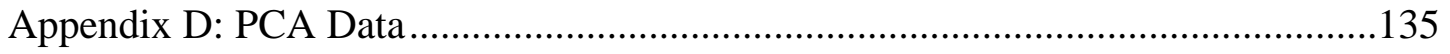




\section{LIST OF TABLES}

Table 1. List of Attributes Used to Assess Nest Site Selection........................................55

Table 2. Consolidation of The 16-Class Land Cover Scheme to Four

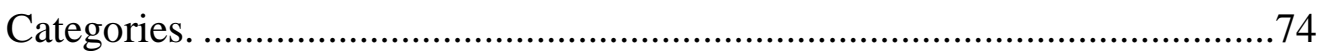

Table 3. Descriptive Statistics Results for Each Attribute.......................... 80

Table 4. Results of The Independent Samples $t$ Test for Each Attribute. .......................81

Table 5. Results of The Pearson Chi-Square Test of Independence for The Land Cover Categorical Attribute .............................................................. 82

Table 6. Cumulative Variance for Each Component......................................................82

Table 7. Variable Loadings for Each Principal Component..............................................84

B8. Nearest Neighbor Distance (NND) of The Peregrine Falcon

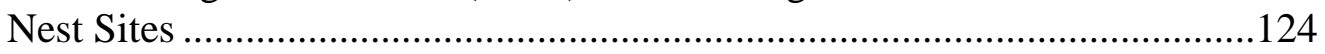

B9. Distance of Peregrine Falcon Nest Sites to Sensitive Species

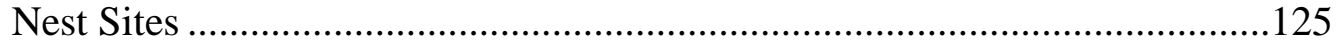

B10. Distance of Peregrine Falcon Nest Sites to Water …………………….........126

B11. Nest Site Categories................................................................................126

B12. Land Cover Codes from NLCD 2011_...................................................127

C13. Data Sheet for Descriptive and Inferential Statistics.....................................130

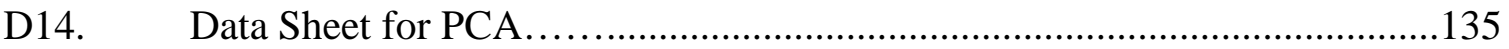




\section{LIST OF FIGURES}

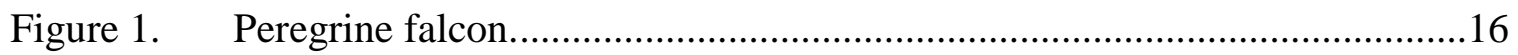

Figure 2. Peregrine falcon on the San Francisco PG\&E building. ............................17

Figure 3. Peregrine falcons on the San Francisco-Oakland Bay Bridge. ....................18

Figure 4. The distribution of peregrine falcon breeding habitat in

North America. ...................................................................................22

Figure 5. A resident pair on gravel substrate in a nest box and a peregrine falcon with eggs in a sand bag. ............................................. 27

Figure 6. A western snowy plover with chicks...................................................32

Figure 7. $\quad$ Peregrine falcons perched on driftwood and a hunting blind.....................34

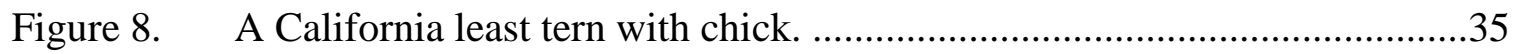

Figure 9. Study area - San Francisco Bay Area, California.....................................52

Figure 10. Elevation within the $30.48 \mathrm{~m}$ buffer at each peregrine falcon nest location .............................................................................. 62

Figure 11. Percent slope for the study area.....................................................64

Figure 12. Wind speed within the $2.41 \mathrm{~km}$ buffer at each peregrine falcon

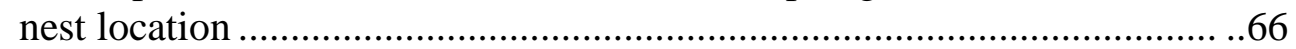

Figure 13. Solar radiation within the $2.41 \mathrm{~km}$ buffer at each peregrine falcon nest location..................................................... 68

Figure 14. Precipitation within the $2.41 \mathrm{~km}$ buffer at each peregrine falcon nest location .................................................................................... 70

Figure 15. Temperature within the $2.41 \mathrm{~km}$ buffer at each peregrine falcon nest location

Figure 16. Land cover within the $2.41 \mathrm{~km}$ buffer at each peregrine falcon

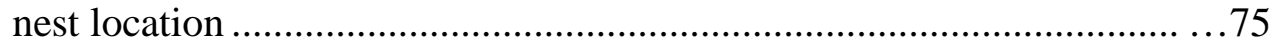

Figure 17. Average nearest neighbor tool statistical output in ArcMap......................79 
Figure 18. Variable loadings of eight peregrine falcon nest site attributes

depicted in two dimensions (Dim 1 and 2)

Figure 19. Principal component graph showing peregrine falcon nest sites as scores with land cover overlay

Figure 20. Descriptive statistics for elevation .................................................115

Figure 21. Descriptive statistics for slope......................................................116

Figure 22. Descriptive statistics for wind speed ...............................................117

Figure 23. Descriptive statistics for solar radiation ............................................118

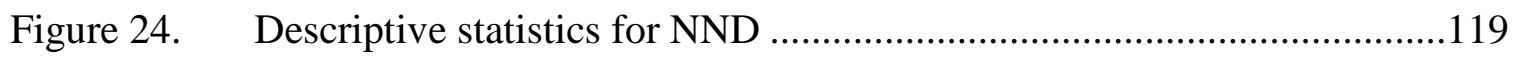

Figure 25. Descriptive statistics for precipitation ...............................................120

Figure 26. Descriptive statistics for distance to federally listed species ..................121

Figure 27. Descriptive statistics for distance to water ........................................122

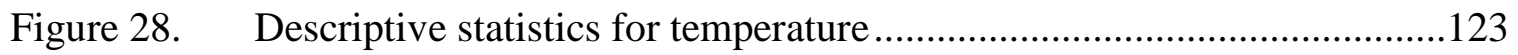




\section{Introduction}

Global human population growth has directly impacted natural habitats, causing intense fragmentation and degradation as they are converted to human use (Chace \& Walsh, 2006). Fragmentation due to urbanization can also affect critical ecosystems that may be the niche habitats for various species (Palomino \& Carrascal, 2007). Predatory birds or raptors are one group of species greatly affected by these changes (Rullman \& Marzluff, 2014) due to their affinity for nesting territories, prey dependencies and small population sizes. Also, these apex predators are adversely affected by habitat loss due to their high resource requirements such as the need for large home ranges (Isaac, White, Ierodiaconou, \& Cooke, 2013). Carter, Moscato, and Tindale (2009) determined that with increasing human impacts on raptor natural habitats and the lack of understanding of raptor population dynamics, it is important for conservation managers to play an active role in promoting the coexistence of these species in urban environments.

Raptors are birds of prey belonging to the scientific orders Strigiformes and Falconiformes (Morishita, Fullerton, Lowenstine, Gardner, \& Brooks, 1998). They are keystone species that serve as indicators of ecological health in their habitat and subsequently for the prey species that they rely upon (Newton \& Olsen, 1990; Weidensaul, 2004). Their position at the topmost trophic level has cascading effects in the ecosystem. The decline or elimination of raptors due to anthropogenic causes allows for proliferation of mesopredators that move in to fill that predation void. It also causes an excess of prey populations which creates an imbalance that can negatively impact the biodiversity of the ecosystem (Isaac et al., 2013). 
Historically, humans have either directly competed with predators (Burnham \& Cade, 2003) by hunting the same prey or have sought to eliminate populations of wolves (Canis lupus), mountain lions (Puma concolor), hawks (Accipitridae/Buteo), and eagles (Haliaeetus/Aquila) that were perceived as competitors. They have been persecuted for centuries (Bijleveld, 1974) and some have also been decimated by pollutants especially organochlorine pesticides such as Dichlorodiphenyltrichloroethane (DDT) (Burnham \& Cade, 2003).

Although often misunderstood, raptors provide many benefits to humans. Since they occupy the highest position in the trophic levels, they are affected by even the slightest changes in the lower dependent levels (Donázar et al., 2016). When the species at the higher trophic levels exhibit high reproductive success, it is a good indication of the health of their environment (Smits \& Fernie, 2013). Raptors help control rodent populations and maintain healthy prey populations by feeding on sick and weak individuals. Carrion feeders such as the turkey vulture (Cathartes aura) control the spread of diseases by consuming diseased carcasses. They maintain the delicate balance in the ecosystem by ensuring no one species population displays a dramatic increase in numbers, thereby regulating prey populations (Sorace, 2002). They serve as natural pest control for invasive species in agricultural lands and are an incentive for the farm industry to avoid the use of harmful pesticides and insecticides (Whelan, Wenny, \& Marquis, 2008).

In the US, laws such as the federal Endangered Species Act (ESA) have been instrumental in recovering predatory species (Marshall, Stier, Samhouri, Kelly, \& Ward, 
2016). One species that has benefited from this protection is the peregrine falcon, which was federally listed as an endangered species in 1970 using a precursor to the ESA. Although “delisted” since 1999 (Federal Register, 2006), it holds a federal status of a "Bird of Conservation Concern" (Pries, 2015) and is a state "fully protected" species in California. It is also protected under the Migratory Bird Treaty Act (MBTA) (Fischer, 2000).

Peregrine falcon populations plummeted as a result of DDT in the environment by the late 1960s. When DDT was banned in the US, the peregrine falcon population began to rise with the support of captive breeding and release programs, and is a true conservation success story (Green et al., 2003). Part of the success of peregrine falcons in the US has been its ability to adapt and thrive in urban environments (White, Smith, Bassett, Brown, \& Ormsby, 2018). However, there is little information on the habitat characteristics sought by urban peregrine falcons or how their populations might change in the near future.

\section{Human-Raptor Relationship}

“Man is the adult Peregrine’s worst enemy” (Hickey, 1942, p. 192). Humans have admired raptors for their ability to hunt and at the same time they were persecuted because they attacked livestock, chickens, and geese (Newton, 1979). Raptors such as peregrine falcons were culled for taking pigeons (Columbidae), their prime food source, and were accused of attacking humans (Hickey, 1942; Herbert \& Skelton, 1965). Persecution also came in the form of unrestricted collection of eggs and eyasses repeatedly from the same eyries through the years by oologists and falconers as well as 
the decimation of mated pairs (Hickey, 1942; Bond, 1946). Peregrine falcons were viewed as competitors for small game and were shot irrespective of seasons on private lands, reservations, and even in states where they held a "protected" status (Hickey, 1942). Such persecution was further compounded by the lack of support they received from ornithologists and conservationists in the nineteenth century. The conservation groups at that time, such as the Audubon and Wildlife Conservation Society did nothing to save raptors such as the bald eagle (Haliaeetus leucocephalus) from near extinction (Newton, 1979).

For centuries, humans have kept raptors such as the peregrine falcon for their highly skilled abilities to scatter, flush, and hunt other bird species and were regarded as ideal for falconry (Larson, Rowe, Breininger, \& Yosef, 1994). Captive peregrine falcons are also used as a deterrent at airfields where there is an abundance of pigeons (Columbidae) and starlings (Sturnus vulgaris) that make up an integral part of the falcon's diet. At military bases, commercial airports and even at the space shuttle landing facilities, peregrine falcons serve to minimize air traffic collisions caused by birds (Kitowski, Grzywaczewski, Cwiklak, Grzegorzewski, \& Krop, 2011; Larson et al., 1994). They are also used to scare away large numbers of gulls at landfills and dumpsites (Soldatini, Albores-Barajas, Torricelli, \& Mainardi, 2008).

There are many continuing significant threats (Pagel, Bell, \& Norton, 1996) to peregrine falcons and other raptors including: environmental contaminants such as DDT in countries where it is still not banned, and potentially affects migrating raptors such as the peregrine falcon; loss of natural landscapes; falconry; predator deterrents; rock 
climbing (Brambilla, Rubolini, \& Guidali, 2004); culling of peregrine falcons by pigeon enthusiasts; contraction of trichomoniasis from diseased pigeons (López-López, Verdejo, \& Barba, 2009); electrocution due to power lines; wind turbines (Noguera, Pérez, \& Mínguez, 2010); tall buildings with glass windows; radiant heat from iron girders on bridges bakes the eggs in the case of bridge nesting birds (Hurley, 2013); vehicle collisions; grounded injured birds or fledglings (Stewart, 2016); and collisions with windows accounting for nearly $45 \%$ of mortality rates of urban raptors (Hager, 2009).

The bald eagle, the peregrine falcon, the golden eagle (Aquila chrysaetos) and the California condor (Gymnogyps californianus) are also affected by lead poisoning caused by hunters using lead shots or bullets. Ingestion of prey birds exposed to lead at both sublethal and lethal levels affects these top avian predators (DeMent, Chisolm, Barber, \& Strandberg, 1986).

Chemicals in the environment continue to affect these top predators today. For example, endocrine biochemical levels for albumin and alkaline phospotase were found to exceed normal ranges in nesting peregrine falcons after exposure to major chemicals such as DDE, a primary metabolite of DDT and polybrominated diphenyl ethers (PBDE) around the Great Lakes Basin of Canada (Smits \& Fernie, 2013). The peregrine falcon is an ideal indicator of environmental health in areas of environmental concern (Clark, Zhao, \& Kane, 2009).

\section{The American Peregrine Falcon}

The American peregrine falcon is about 0.49 meters tall (Figure 1) (TheCornellLab, 2010) and is sexually dimorphic in size with the females being one-third larger than the 
males at an average weight of 900-1000 g (White, Cade, \& Enderson, 2013). This bird's streamlined physiology allows for high speeds while in aerial pursuit of its prey and its optimal prey size is about 200-400 g (Kaufman, 2001).

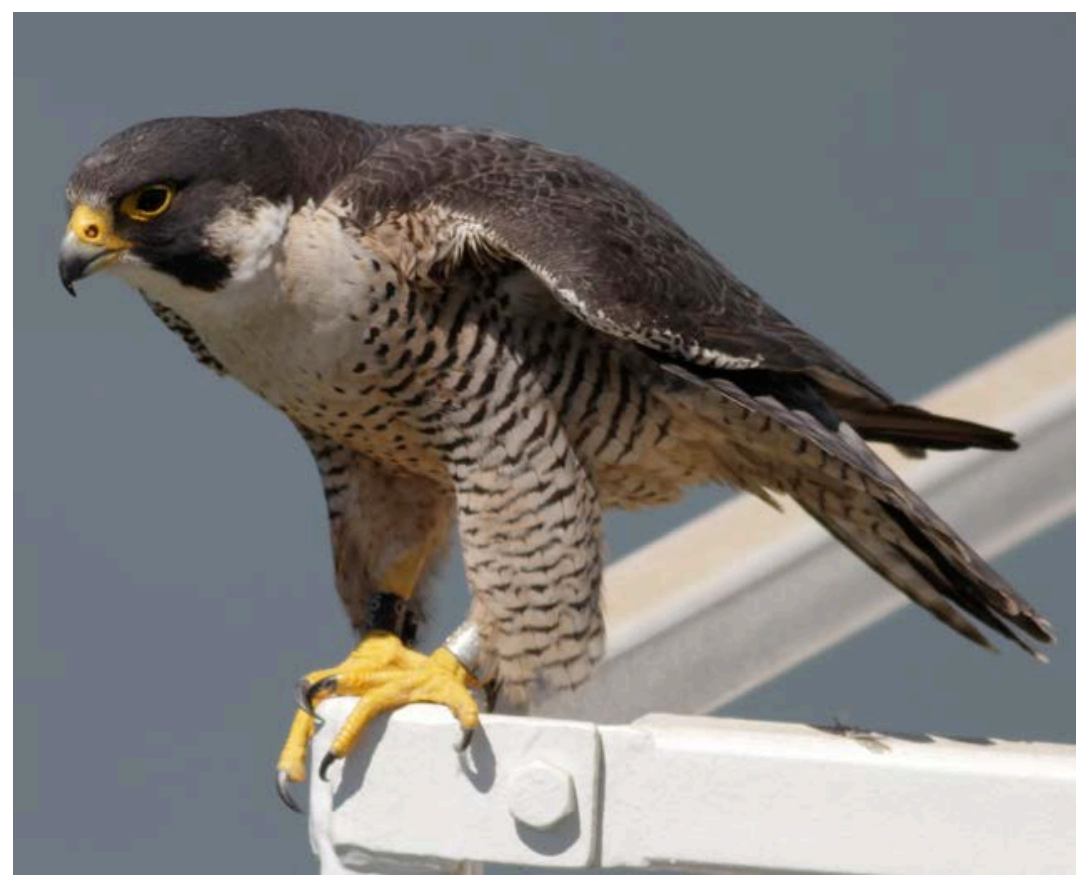

Figure 1. Peregrine falcon. Photo taken by Mary Malec.

In North America, historically it was also known by its common name the "duck hawk”. The subspecies nomenclature F. peregrinus anatum is derived from the Latin word “anas’ for “ducks” (White, Cade, \& Enderson, 2013). The peregrine falcon’s primary diet consists of birds mostly captured in flight (Thatcher \& Smith, 2005) and its ability to catch birds in mid-air makes it a unique hunter in nature (Burnham \& Cade, 2003). It belongs to the family "Falconidae" and order "Falconiformes". Their historical habitat includes steep cliff sides, rocky ledges and outcrops with level shelves, caves and crevices, vast open expanses for hunting, coastal beaches and cliffs alongside stretches of water elements like rivers, wetlands, lakes, and streams (Ratcliffe, 2010). The peregrine 
falcon has an affinity for "cliff-like” ledges and a body of water in close proximity (Khlopotova, 2013) and an urban setting with tall buildings mimics this for the most part. Its home range is typically between approximately 17 to $40.5 \mathrm{~km}^{2}$ (Brown \& Amadon, 1968).

One of the earliest documented anthropogenic nest sites of the peregrine falcon was in the eastern United States, on a stone-bridge pier [ca. 1939] (Hickey, 1942) and they were spotted nesting on a barrel, an oil derrick and a power pole platform [ca. 1927] respectively in the western United States (Bond, 1946). In 1943, Herbert and Skelton (1965) documented the first known peregrine falcon nest on the St. Regis Hotel in New York City. While in Europe, peregrine falcons have been spotted nesting on the Salisbury Cathedral in England [ca. 1896]. In the twenty-first century its primary environment in several known cases includes tall building structures (Figure 2), smoke stacks, power towers, suspension and regular bridges (Figure 3) and water towers.

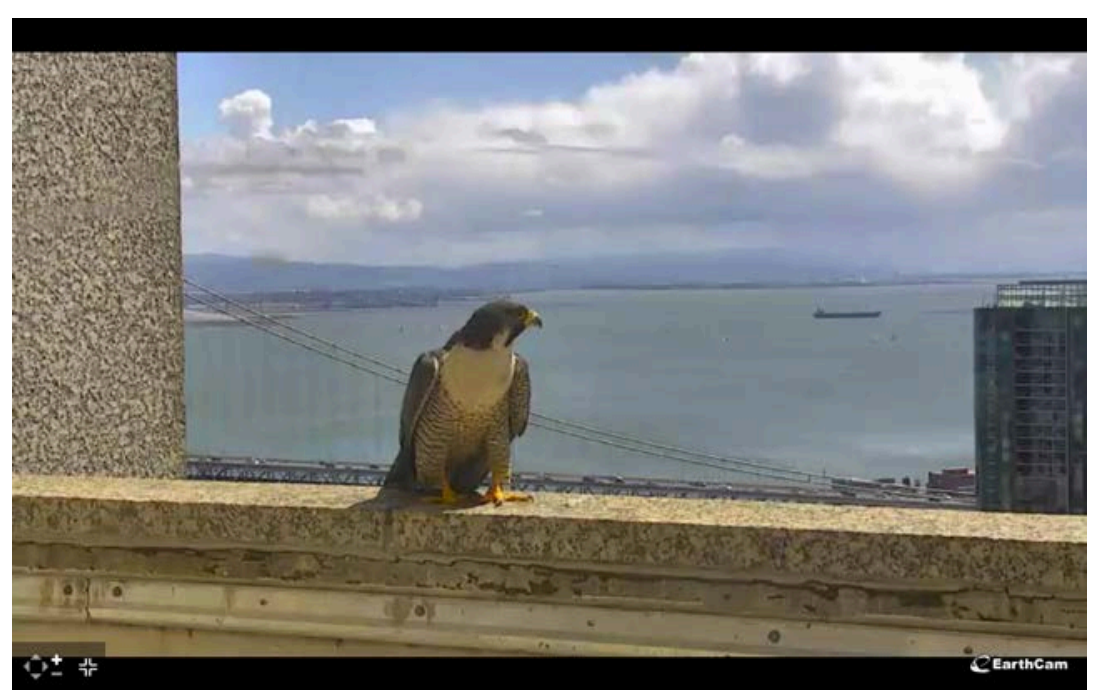

Figure 2. Peregrine falcon on the San Francisco PG\&E building. Photo taken by Mary Malec. 

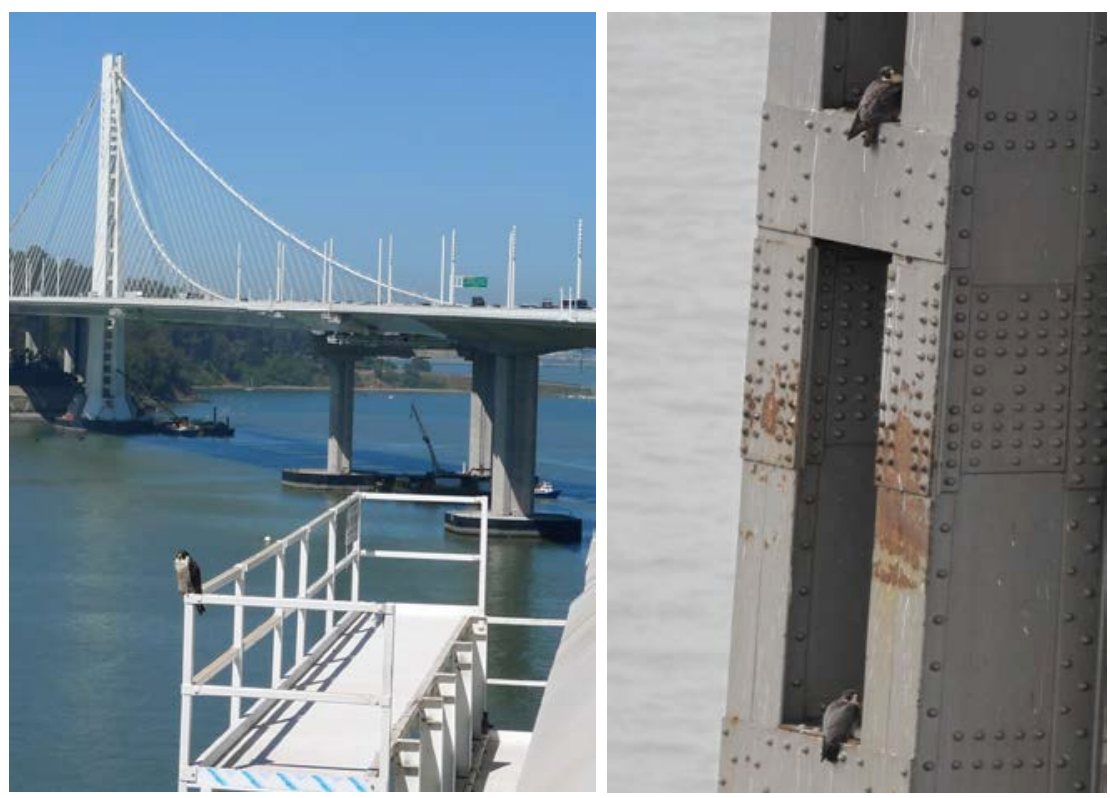

Figure 3. Peregrine falcons on the San Francisco-Oakland Bay Bridge. Photos taken by Mary Malec.

The urban “cliffs” (Fischer, 2000) parallel historical natural sites in having a similar micro-climate, topography and unprecedented views of prey (Hinchliffe \& Whatmore, 2006). Natural nest sites are typically located on cliffs or rocky outcrops with level shelves or cave openings where the eggs are laid on a flat area containing enough gravel or soil substrate for the birds to make a scrape or depression; while in the urban setting, nest boxes with gravel substrates located on structures serve the same purpose. According to U.S. Fish and Wildlife Service (USFWS) (Green et al., 2003), as of 2003, 92\% of breeding peregrine falcons nested on natural substrates in most regions except in the Midwest. But, this estimate is probably leaning more towards urban areas today.

Pesticide use and post-recovery. The discovery of the "wonder chemical” DDT as a pesticide compound in the 1930s and its widespread use beginning in World War II adversely affected the survival of raptors in the United States and elsewhere (Ratcliffe, 
2010). Predatory birds that consumed contaminated prey were gravely affected due to bioaccumulation, which is the prolonged absorption of toxins from the environment that affects the bird physiology (Seress \& Liker, 2015) resulting in reproductive failures. The peregrine falcon among others showed serious population decline in the 1950s and 60s due to bioaccumulation effects (Brown et al., 2007). Persistent organochlorine pesticides especially DDT resulted in thin shelled eggs and subsequent reproductive failures (Zarn, 1974). By 1967, there was a significant and serious decline in the British and North American peregrine falcon populations (Burnham \& Cade, 2003).

In the United States, the breeding population to the east of the Mississippi River estimated at 350 pairs prior to 1942, was extirpated by 1964. In California, there were at least 100 pairs estimated in the pre-pesticide era (Bond, 1946) but the population dwindled to only two breeding pairs by 1972 (Kauffman, Pollock, \& Walton, 2004; Stewart, 2016). The peregrine falcon was listed as endangered in 1970 under the initial directive of the ESA (Federal Register, 2006). Smaller subpopulations of the peregrine falcons may be susceptible to allele drifts and inbreeding reducing its genetic variability and leaving it at high risk of extinctions due to its K-selected strategies (Brown et al., 2007; Burnham \& Cade, 2003) for survival. This situation may have been exacerbated by the species drastic decline due to DDT.

The peregrine falcon has adapted remarkably well to human disturbances and urbanization (Cade, Martell, \& Redig, 1996). In terms of the population in all of North America, there were an estimated 2000 pairs at the turn of the century and at that time resident peregrines on eyries were replaced fairly quickly (in a timeframe of six hours to 
two weeks) both in Europe and in North America (Hickey, 1942) implying the existence of adult floaters in the population (Hunt, 1998). But, by 1965, Herbert and Skelton (1965) found replacement of territorial mates by conspecific individuals had become a rare occurrence. After legal protection, peregrine falcons numbered approximately 325 pairs in all of North America by 1974. According to USFWS, it is estimated that as of 2003 there were 3,005 pairs of nesting falcons in the U.S, Canada and Mexico (Green et al., 2003) and more than 300 pairs in California (Stewart, 2016). The new populations of peregrines come from a genetic stock of more than five subspecies (Tordoff \& Redig, 2001). Tordoff and Redig (2001) point out that the diverse genetic stock and the new urban inclined peregrines together provide a solid base for the action of natural selection.

The post recovery urban North American peregrine falcon species consists of three subspecies F. p. anatum, F. p. pealei, and F. p. tundrius (Burnham \& Cade, 2003) (Figure 4). Although the two subspecies, F. p. anatum and F. p. tundrius were historically not too genetically different, these subspecies do exhibit perceived ecological differences now possibly due to anthropogenic influences (Brown et al., 2007). The subspecies that is prevalent throughout California is the F.p. anatum (Thelander, 1977). 


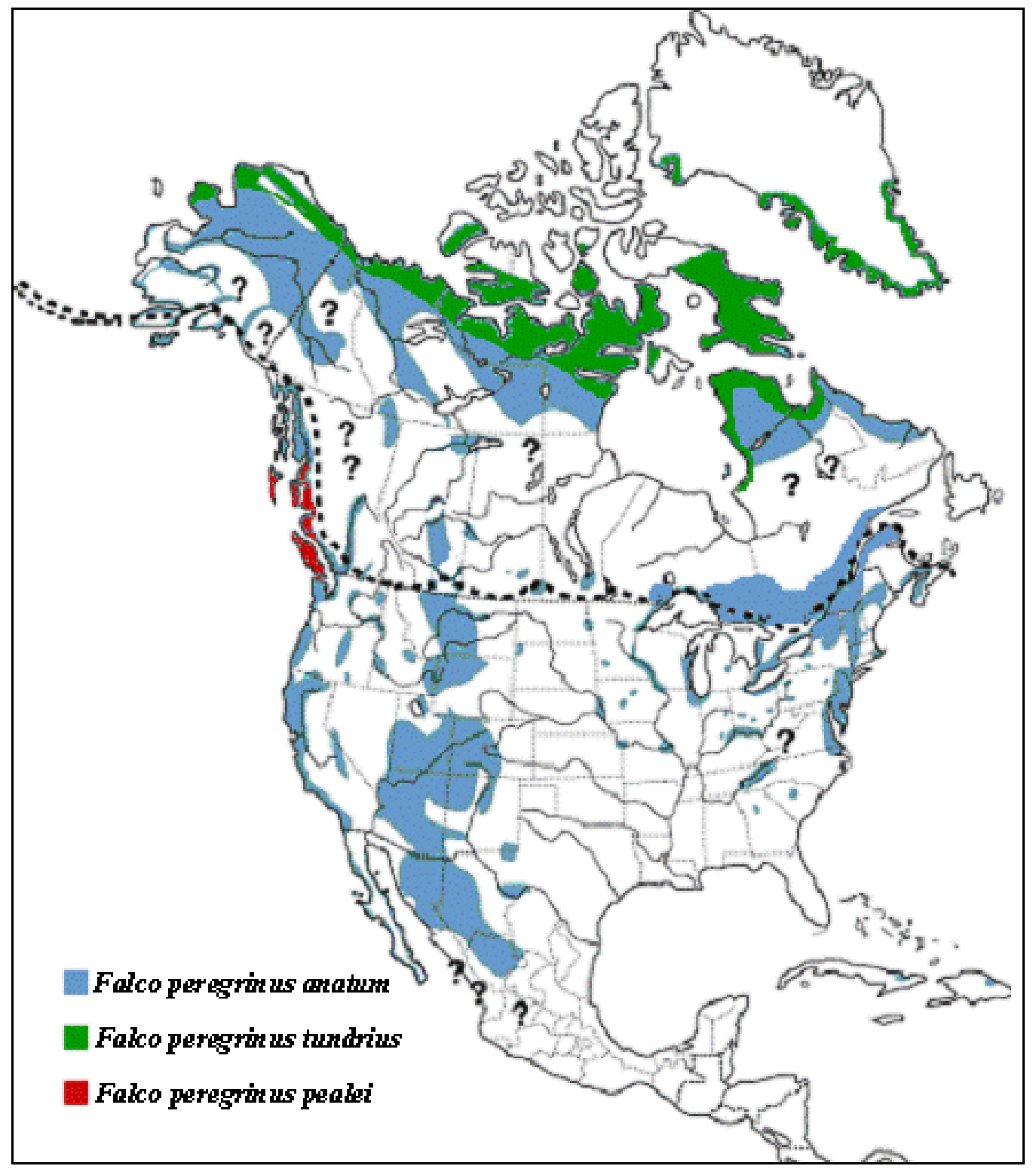

Figure 4. The distribution of peregrine falcon breeding habitat in North America. Map reprinted with permission from White, Clum, Cade, and Grainger (2002) and SARA (2016).

A combination of efforts contributed to the recovery of this species. Efforts included the complete eradication of DDT use and an intensive captive breeding and release program across the United States. The peregrine falcon recovery story is the direct result of the success of the ESA that first helped the species get listed as endangered followed 
by its delisting in 1999 (Kauffman, Frick, \& Linthicum, 2003). The extensive banding and monitoring programs spanning several years and the in-depth knowledge of the biology of the species have also contributed to their successful recovery. The peregrine falcon is a unique species that has recovered after almost being extirpated (Scott, Goble, Haines, Wiens, \& Neel, 2010; Kauffman et al., 2003).

The San Francisco Bay peregrine falcon subpopulation habitat study conducted in this research will help wildlife managers understand the urban peregrine falcon habitat requirements and how they can support and manage this species in terms of the urban breeding populations and interactions with other sensitive prey species. 


\section{Related Research}

\section{Urban Ecology}

Management of biodiversity within urban ecosystems involves a comprehensive understanding of the complex intertwining of the hierarchical framework of organisms, species interaction, habitat influence, and habitat fragmentation causes and effects. This is also known as recombinant ecology and can be the driver for biodiversity management in natural areas (Hinchliffe \& Whatmore, 2006). The dynamic nature of urban ecosystems due to their high diversity can help in the understanding of the biodiversity in other ecosystems (Savard, Clergeau, \& Mennechez, 2000). Biodiversity within urban ecosystems encompasses spatial and temporal scales at both the community level and at a species population level with cascading effects. For example, at the species level, native individual species within an urban ecosystem struggle with co-existing with non-native species, and those that are driven into urban environments from their original natural habitats, such that urban species richness maybe in a state of constant flux (Savard et al., 2000).

Changes exhibited by avifauna in behavior and interactions with natural systems are highly visible and are the ideal gauges for the health of an ecosystem. The existence of greenery of parks, woodlands, wetlands, riparian corridors, provisions of man-made structures for nesting, breeding platforms (Savard et al., 2000), and backyard birding elements such as bird baths and feeders in highly urbanized areas, support both the diversity and abundance of various resident and migratory bird species. This in turn attracts birds of prey and serves as a food source for several species of raptors (Roth, 
Vetter, \& Lima, 2008). And in general, urban raptor populations ensure that no single prey species monopolizes the habitat, an example of a healthy urban ecosystem as evidenced by its cascading effect.

Urbanization is considered to be the prime reason for loss of biodiversity worldwide (Isaac, Cooke, Simmons, \& Hogan, 2008; Marzluff, 2005). The future of wildlife is leaning more towards urban ecosystems as natural habitats continue to disappear to accommodate the ever-growing human populations. Sorace and Gustin (2009b) point out that conservation management should give importance to sensitive species whose ecological needs are opposed to urbanization and for those that occupy the fringe of urban habitats, parklands and edge habitats where there is a higher degree of biodiversity. Marzluff (2005), however, concluded that intermediate disturbance levels and moderate settlements in communities supported the richest diversity among species with regard to songbirds in well-managed urban ecosystems.

The modern fabric of ecology is exemplified by the healthy co-existence of various life forms in an urban ecosystem (Hinchliffe \& Whatmore, 2006). Therefore, the study of wildlife movements into urban areas provides opportunities to better understand urban ecology to greater depths (Rutz, 2008). The effects of urbanization on wildlife is called synurbization (Luniak, 2004) and species that are largely found in the urban ecosystems are referred to as being synurbic. The concept of synurbization is an important aspect of this study since the San Francisco peregrine falcon subpopulation demonstrates unmistakable synurbic qualities. Synurbization applies when the urban population size of a particular species is relatively higher than in rural habitats (Francis \& Chadwick, 2012). 
Characteristics that define synurbic populations include lack of migratory behavior, higher population density with reduced territory size, longer breeding season, longevity of individuals due to lack of pressures from predation, nocturnal activity, man-made nesting substrates, anthropogenic food, human tolerance, and aggressive behaviors towards conspecifics. Although the peregrine falcon is not synurbic throughout its entire range, it is reasonable to categorize the San Francisco subpopulation (Sorace \& Gustin, 2009a) and its most favored urban prey generalist Columbidae, as being synurbic (Marzluff, 2005; White et al., 2013). Both species exhibit urban population expansion induced by anthropogenic influences (Francis \& Chadwick, 2012).

The worldwide reintroduction of the peregrine falcon into highly urbanized cities accounts for much larger populations within urban habitats compared to historic rural landscapes. This shift to urban areas is a classic example of synurbization with a positive effect for its population even though there is a mix of natural and urban birds. And, it has induced a new ecological niche for this species (Luniak, 2004). Although in most cases being synurbic does not immediately imply increased urban population densities (Francis \& Chadwick, 2012), it is an important identification for species biodiversity in the emergence of urban ecology and biogeography fields. Urban wildlife ecology is a relatively new but vital field that requires more case studies involving synurbization (Rutz, 2008). A thorough understanding of species that are synurbic, and its ecological importance, would help future urban planners incorporate greener elements in urban areas to support wildlife (Francis, 2011). This phenomenon highlights the possibility for the co-existence of the natural world with urban development (Luniak, 2004). 
The relationship of a species to its environment, its spatial distribution, and environmental conditions that define habitat suitability are important criteria for wildlife management and planning for its habitat protection (Amici, Eggers, Geri, \& Battisti, 2015; Gibson, Wilson, Cahill, \& Hill, 2004; Kassara et al., 2012). In order to develop conservation management plans, it is important to understand the spatial distribution of the species and the environmental attributes that influence its habitat (Gibson et al., 2004; Shabani, McArthur, \& Abdollahian, 2009). In an urban environment, where populations of the species may be quite segmented due to fragmentation, understanding the relationship between a species and its habitat is especially important. Specific environmental predictors that are associated with the biological needs of the species could define the habitat selection and preference of the species (Shabani et al., 2009). And, there is an increasing need to identify these ecological factors for species conservation (Brambilla et al., 2009). Most scientific studies are based on natural environments with only four percent inclusive of urban ecology (Collins et al., 2000). Hence, this research is a contribution towards filling that void.

\section{The Urban Peregrine Falcon}

Whitfield (1985) noted that one of the raptors prevalent in an estuarine ecosystem is the peregrine falcon. The post-recovery peregrine falcon subpopulation in the San Francisco Bay Area has acclimated to using urban structures as sites for nesting including man-made nest boxes, with sand and gravel substrate (Altwegg, Jenkins, \& Abadi, 2014) (Figure 5). 

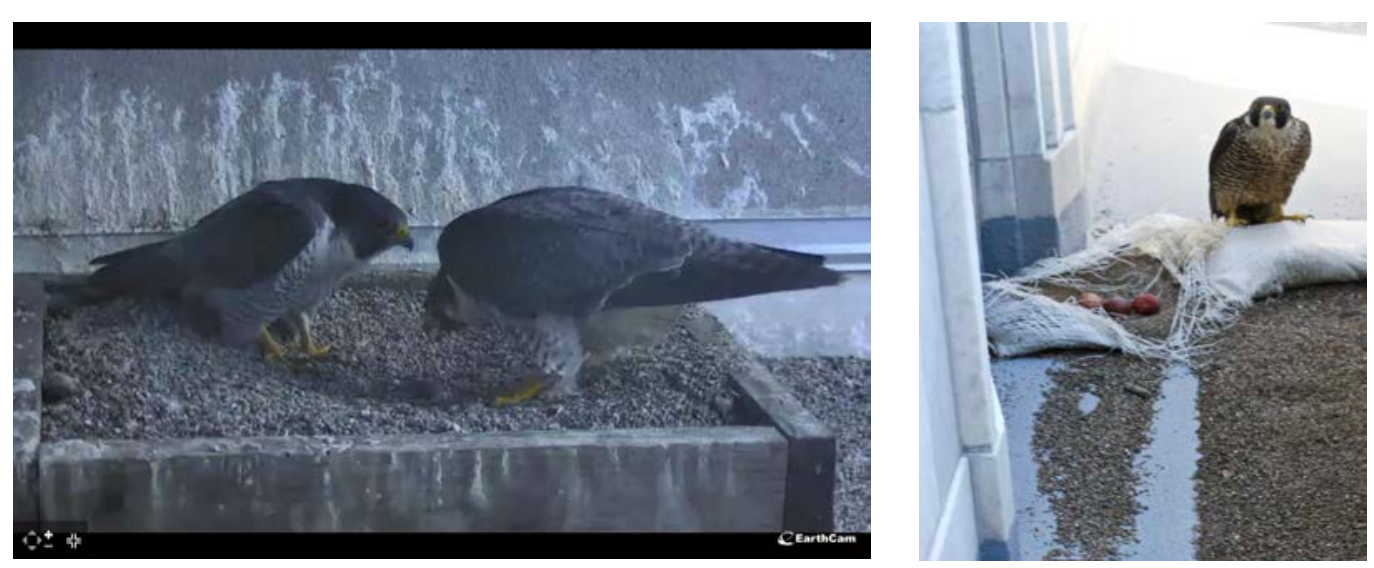

Figure 5. A resident pair on gravel substrate in a nest box and a peregrine falcon with eggs in a sand bag. Photos taken by Mary Malec.

They have taken an affinity for high rises, buildings, transmission towers, loading cranes, smoke stacks, and bridges as nest sites in urban areas (Kauffman et al., 2004; White et al., 2013). The San Francisco Bay Area breeding peregrine falcons are residents that stay year round and have found a large prey base in abundant urban birds such as pigeons/rock doves (Columba livia) (Rejt, 2001) and other bird species en route in their migration through the Pacific Flyway (Wakamiya \& Roy, 2009). San Francisco Bay estuary serves as a vital stopover for almost half the migrating shorebirds using this corridor (Patton, 2002). Non-natives such as the European starling (Sturnus vulgaris) are also an important food source for the urban peregrine falcon (Ratcliffe, 2010) in agricultural pockets around the San Francisco Bay Area. And, it serves as a natural pest control for these non-native species (Tangley, 1986). Hickey (1942) noted that because of this wide variety of prey species, any fluctuations in populations of any single prey species may have little to no impact on peregrine falcon breeding populations. A few benefits for peregrine falcons in urban areas compared to rural habitat include a reduction in predation by Great Horned owls (Bubo virginianus) (Herbert \& Skelton, 1965), 
coyotes (Canis latrans) and bobcats (Lynx rufus) (Stewart, 2016) and an increased opportunity to hunt at night time with the assistance of artificial lights (DeCandido \& Allen, 2006; Kettel, Gentle, \& Yarnell, 2016).

Urban areas provide the three important factors required for the productivity of raptor populations (Rullman \& Marzluff, 2014; Rutz, 2008), especially for the peregrine falcon: abundance of prey bird species, reduction in the risk of predation, and availability of nesting cliffs. The increase in urban peregrine falcon populations across North America can be attributed to an increase in the availability of potential nest sites compared to those in natural and historical cliff habitats. Future vertical urban expansions due to depletion of available natural land areas (Francis, 2011) will favor the peregrine falcon due to its affinity to artificial nesting cliffs. In the Eastern United States, the carrying capacity of peregrine falcon populations increased with an increase in urban nest sites (Gahbauer et al., 2015), while the western population may exhibit in some areas a rural sink population and a growing urban population. A sink population is defined as one in which individual mortality rates in the population are higher than the birth rates in that population (Pulliam, 1988). And, the Midwestern peregrine falcon population is predominantly concentrated in urban areas (Wakamiya \& Roy, 2009) constituting about $80 \%$ of nests on anthropogenic sites (Redig \& Tordoff, 1997).

According to Kauffman, Frick and Linthicum (2003), fecundity rates for peregrine falcons in California were higher in urban territories than in rural areas. They found that peregrine falcons had a higher chance of survival in the urban areas of San Francisco bay during their first year than in the coastal areas due to availability of resources in terms of 
food, nesting areas and lack of potential predators. They also found rural birds dispersed more into urban areas than vice versa for breeding populations.

The health of the population is determined by three primary factors: territory occupancy, successful nesting, and fledging success (Green et al., 2003). Between the years 1950 to 1980, these numbers were severely low for the peregrine falcon but since then, they have experienced a dramatic recovery (Wootton \& Bell, 2014). The USFWS planned to monitor the population at five year intervals since it is still a vulnerable species susceptible to extinction (Green et al., 2003). According to the Goals Project (1999), the peregrine falcon has been identified as a Community Indicator species representing several species sharing similar habitats. It is recognized as both a Habitat Indicator species (meaning they define the habitat with their presence in it and are therefore indicative of the health of that habitat) and as a Sensitive/Protected Species since not too long ago it was endangered although not anymore in California. It is an integral part of the San Francisco Baylands ecosystem and uses the several habitats such as the shallow channels, tidal flats, lagoons, beaches, rocky shores, low/mid/high tidal marshes, diked wetlands, salt ponds, agricultural baylands, grasslands, and oak woodlands for foraging, breeding and roosting (Goals Project 1999).

The peregrine falcon is considered a species of conservation concern by the California Department of Fish and Wildlife and the USFWS (Takekawa et al., 2011). It has proven to be a resilient and versatile species with its current pervasive range, its adaptability to nesting sites and urban prey bird species, its resilience to persecution, its 
recovery and re-introduction from captive-bred genetic stock, and with its present day diverse genetic strains that remain successful in new habitats (Tordoff \& Redig, 2001).

\section{Predator-Prey Dynamics}

Jokimaki and Huhta (2000) determined that ground-nesting bird species in urban environments are highly susceptible to nest predation. Additionally, several case studies in scientific literature have proven that indirect predator effects exemplified by presence of a predator in the vicinity of prey populations does affect the prey population dynamics (Cresswell, 2011). Shorebird populations and their abundance are significantly affected by raptors directly or indirectly especially due to predation of adult breeding-age birds.

The abundance of shorebirds is predominantly affected by their foraging capabilities in the non-breeding seasons. The wintering season is the prime time for shorebirds to fuel up their reserves for the forthcoming breeding seasons. This is very much defined by the presence or absence of raptors and availability of sufficient food sources in foraging areas (Whitfield, 2003). Raptors affect the foraging efficiency of shorebirds both in terms of time and quality (Quinn, 1997). Surprise and stealth are two strategies employed by raptors like the peregrine falcon to catch its prey, especially within open habitats such as salt ponds and tidal mudflats (Cresswell, 1996; Ydenberg \& Dekker, 2004). Similarly, prey species adapt to certain tactics to avoid predators as seen in the behavior of Dunlins that opt to synchronized flights, flying low over the ocean in the presence of peregrine falcons (Buchanan, 1996).

Coastal shorebird communities and their abundance are directly affected by the

presence of peregrine falcons (Lourenço, Catry, Lecoq, Ramírez, \& Granadeiro, 2013). 
The slightest sense of a peregrine falcon nearby causes all shorebirds to flee and to be wary of their surroundings often clearing long stretches of coastline in a short timeframe. It is a behavioral paradigm for the peregrine falcon to go back to its favorite perch around the same time of the day and stay for several hours before resuming hunts (Dekker, 2009). Y Ydenberg, Butler, Lank, Smith, and Ireland (2004) determined that regardless of the number of the predator species present in a prey habitat, it left long term lingering perceived predation deterrent behavior exhibited by the prey species long after the predator had left the area. But, Cresswell (2011) also determined that predation on a more preferred and profitable species tends to leave the population density of other prey species less affected by predation. Hence, there are direct and indirect effects and consequences to the presence of top predators in the proximity of prey habitats (Cresswell, 2011; Ydenberg et al., 2004). Cresswell (2011) also concluded that displacement of one predator species does not necessarily affect the prey species population densities since they are still vulnerable to other predation effects. Therefore, a thorough assessment of the habitat and conservation needs of both predator and prey bird species needs to be evaluated for long-term management goals (Smith, Pullin, Stewart, \& Sutherland, 2010).

There are challenges faced in conservation efforts with the recovery of a protected predator species that targets protected prey species especially when they occur in close proximity (Garrott, White, \& White, 1993; Marshall et al., 2016). In the history of conservation biology, while nearly extinct species are given priority and rare species are paid great attention, often overlooked are the negative effects of a possibly thriving 
sensitive species on another sensitive species that is not doing as well. As an example of this, in the San Francisco Bay Area, peregrine falcons have been reported to be a significant threat to the western snowy plovers (Charadrius nivosus nivosus), described in the following section. This research discusses the direct/indirect impacts of the protected species peregrine falcon on the sensitive species of concern, the western snowy plover and the endangered California least tern.

The western snowy plover. The western snowy plover is a small semi-colonial ground nesting shorebird about the size of a sparrow (Figure 6). The clutch size is about three eggs that are directly laid on the sandy substrate in a scraped area (Fancher, Knapp, \& Hays, 2007). The breeding populations of the western snowy plover range along the Pacific Coast from the southern end of Washington State to Central America.

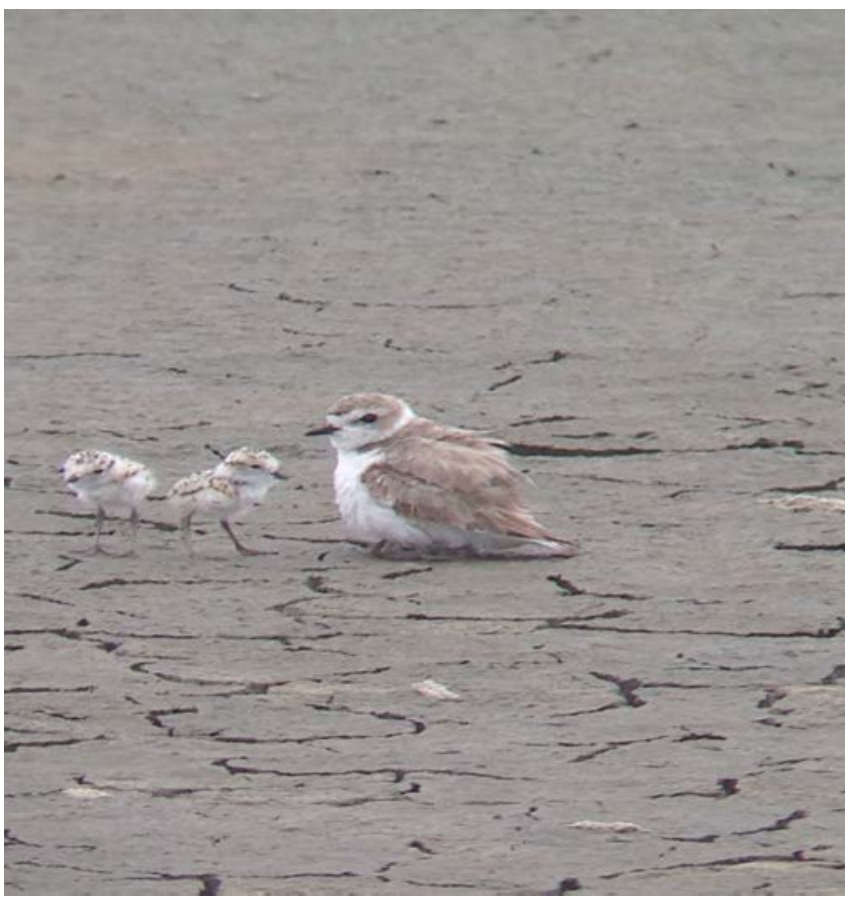

Figure 6. A western snowy plover with chicks. Photo taken by Benjamin Pearl. 
The habitats for both breeding and non-breeding seasons are coastal beaches, salt ponds, and mud flats (Hornaday, Pisani, \& Warne, 2007). Having lost its historical habitat of beaches and salt pannes to human encroachment and habitat destruction, the species has adapted well to a suboptimal habitat in the salt ponds around the perimeter of San Francisco Bay where its population stands at approximately 200 birds (Tokatlian, 2017). It holds a status of being a federally threatened and California species of special concern bird.

The recovery goal for the state is about 3000 breeding capable individual birds and 500 for the San Francisco Bay Area. The peregrine falcon has been determined to be one of many threats to this species in the southern San Francisco Bay Area. The open salt panne habitat that characterizes this part of the bay is ideal for the western snowy plover but makes them vulnerable targets for raptors such as the peregrine falcon, which prefers to hunt overlooking vast open space habitats. Western snowy plovers that were in nests did not necessarily fly away when a peregrine falcon was in the area. Instead, they had the tendency to crouch down to avoid predation (Robinson, Demers, \& Strong, 2010).

The peregrine falcon has been identified in the most recent habitat selection study conducted for the South Bay Salt Ponds Restoration Project as one of the key threats to the western snowy plover breeding success at the salt ponds. They have been observed resting on power transmission towers around the western snowy plover monitoring complexes (Robinson-Nilsen, Demers, \& Strong, 2011). Occasionally they have been observed taking western snowy plover chicks from nests (B. Pearl, personal communication, September, 2015). The removal of perches and hunting blinds (Figure 
7) that provide a hunting base amidst a colony of nesting western snowy plovers and/or dissuasion of peregrine falcons within foraging distance of western snowy plover colonies have been recommended as intensive management strategies (Pearl, 2015; Tokatlian, 2017).
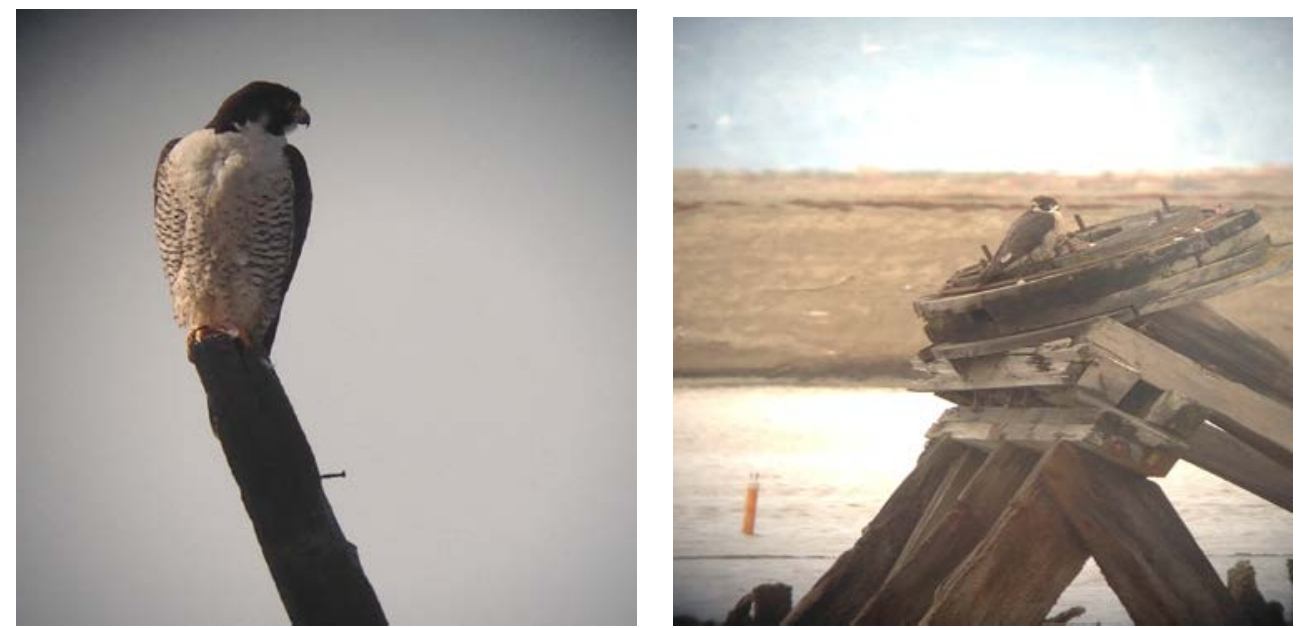

Figure 7. Peregrine falcons perched on driftwood and a hunting blind. Photos taken by Benjamin Pearl.

Periodically active peregrine falcon nests observed in the western snowy plover restoration complexes have been dismantled prior to winter season to prevent and dissuade future nesting at those locations (Tokatlian, Scullen, \& Burns, 2014) as in the case of the plover project at Bolsa Chica where the very consistent presence of a peregrine falcon was disrupting shorebirds. Gun hazing with cracker shells was used but was ineffective since the peregrine falcon returned to the same area (Fancher et al., 2007).

Within the San Francisco Bay salt ponds ecosystem, peregrine falcon numbers since 2004 to 2008 have shown definite growth and have risen in rankings as a distinct predatory threat to the western snowy plover (Robinson-Nilsen et al., 2010, 2011). Being 
semi-colonial nesters, the western snowy plovers are difficult to manage because nest sites are dispersed and hard to visually detect in the salt ponds, but this could possibly be to their advantage since it might evade aerial predation because of their more scattered breeding and foraging behavior.

The California least tern. The habitat for the California least tern, another groundnesting species (Figure 8) ranges from the San Francisco Bay Area to Baja California, Mexico along the western coast of the United States (Elliott, Hurt, \& Sydeman, 2007). They prefer sandy substrates with no vegetation to enable them to watch for predators in their habitat.

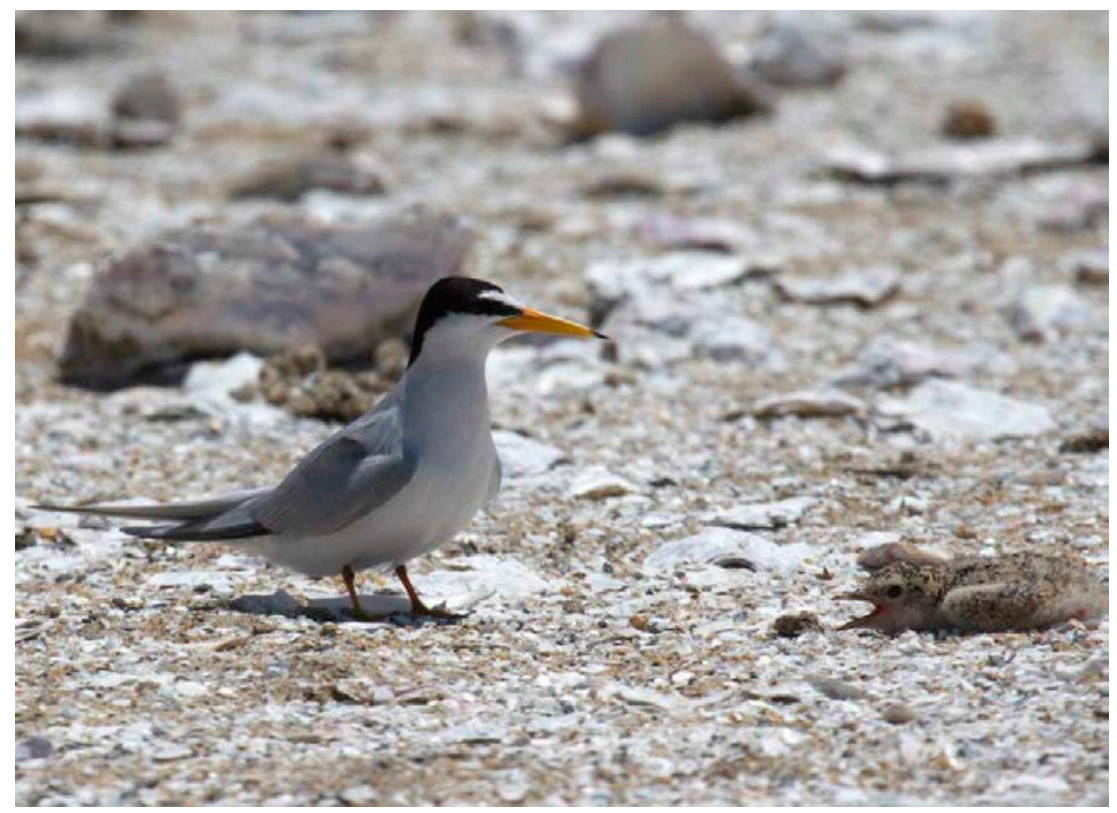

Figure 8. A California least tern with chick. Photo taken by Rick Lewis (goldengateaudobon.org).

Historically, their habitat was also coastal dunes and lagoons along the beaches and oceanfront that have been disturbed significantly by human interference (Butchko, 1990). The dramatic loss of habitat contributed to its severe decline in population numbers and 
was listed as endangered by the ESA in 1973. It was estimated in 1990 that there were 30 colonies remaining in California.

The peregrine falcon is listed as one of its major threats and in 1989 it was observed around the least tern colony in Southern California and was recognized as a sensitive resource management matter due to its status as endangered (Butchko, 1990). California least tern adults and fledglings are most affected by peregrine falcon predation (Elliott et al., 2007). One of two California least tern colonies in the San Francisco Bay Area is concentrated on a ten acre plot of habitat in Northern California and is very much at risk of aerial predation.

Several decades ago, the least terns sought out the naval airstrip at Alameda Point while it was still active, and the U.S. Navy started protecting them (J. Albertson, personal communication, September 2015) a decade ago via an agreement with USFWS. The veterans' administration subsequently took over the area and designated the entire former airstrip tarmac as a wildlife reserve. Terns return to the Alameda Point year after year and have established this colony historically since the 1970s. This is one of its northernmost breeding grounds and they winter in South America. The least tern population although fairly stable in the last few years, are still vulnerable and hence a federally listed endangered species (J. Albertson, personal communication, September 2015).

Currently, the least tern colony area is situated within a 10-acre area surrounded by a four feet high chain link fence to keep out mammalian predators. Terns like to be able to see predators, so the tarmac is routinely cleared of all vegetation and perches to dissuade 
avian predators. Despite these efforts, there are still many nesting opportunities for peregrine falcons within flying distance of the least tern colony such as the massive cranes at the Port of Oakland, the bridges straddling the bay, and numerous power transmission towers. During the nesting season there are about a 1000 chick shelters that are arranged within the enclosed area for the chicks to hide under when needed. Oyster shells are also spread out all over the area to provide camouflage opportunities for the birds and chicks.

The former Alameda military airstrip is an invaluable location to conduct effective management designed to help the least tern colonies thrive. The colony number is around 400-600 individual terns and there were about 300 fledglings in 2015. A fledgling rate of 0.87 indicates a stable population and the Alameda site has had the highest fledgling success in the state for many years because of effective management (Elliott et al., 2007). Due to the small area of the nesting colony, resource managers are able to provide high levels of protection and these colonial nesters can therefore attain fledgling success. Nonetheless, one persistent predator like a kestrel (Falco sparverius) or a peregrine falcon can wipe them out and a high level of active observation and human management is required to achieve a sustainable fledgling rate. The least terns do mob predators but several peregrine falcons present in the area can affect the colony dramatically. For example, a few years ago, a kestrel repeatedly attacked the colony due to high vegetation on the tarmac, and this necessitated active management, to keep the tarmac clear and remove high cover-worthy vegetation. 
To prevent and protect against predation, the following methods were adopted: mammalian predators were lethally removed; with avian predators, a step-wise integrated predator management was taken wherein all posts and perches were removed and all vegetation on the tarmac was removed; addling/oiling of the eggs of predatory birds (Stewart, 2016) destroyed the hatching but still kept the adults on the nest. This helped the terns handle the predation pressure during periods when raptors had young to feed and the oiling of the eggs prevented them from having young and from re-nesting.

Peregrine falcons are deterred by humans with flares, party poppers (Stewart, 2016) or by honking. But, couple of the birds were captured and relocated due to repeated attacks of the colony and the drastic measure was taken to protect the colony from getting decimated. In general, however, relocation has been ineffective (Garrott et al., 1993) since the peregrine falcons typically returned to their territories. Hence, the resource managers have realized that relocation does not work and now they have the added challenge of an educated bird that is difficult to capture. The prevention of raptors in the area from having young and lethal removal in some cases, were primary tools that helped in the success of the California least tern population in this colony. And, in the case of peregrine falcons, dissuasion from nesting by dismantling nests was an effective strategy.

Although small shorebirds constituted less than three percent of prey captured by peregrine falcons (Stevens, Brown, \& Rowell, 2009), predation on the California least tern colonies in San Diego Bay have raised alarms with resource managers regarding the same behavior in the northern San Francisco Bay Area. Peregrine falcons have adapted to high man-made structures such as the San Francisco Golden Gate and Oakland Bay 
Bridges as nesting or resting sites to hunt from, making nearby California least tern colonies, easily observable from these high locations and quite vulnerable to predation (Cohen, 2010).

Snowy plovers and California least terns have been greatly affected by habitat loss to encroaching development and human recreation. This in turn allows mesopredators, nonnative predators, and predators who do well in urban settings to proliferate. Although the peregrine falcon is an endangered species, it has recovered and is adapting very well to urban infrastructure, so much so that it is now a potential threat to other species.

Whether relocating raptors is effective at protecting species they prey upon is subject to debate, given the cost of such projects is dependent on the particular predator species and the goals of the relocation (Curtis, Cepek, Mihalco, Seamans, \& Craven, 2013). For example, in San Diego, California, a pair of peregrine falcons nested on a flat beach terrain about $60 \mathrm{~m}$ from an active western snowy plover nest. The nest was abandoned within a week of the peregrine falcons laying two eggs in their scrape. The proximity of the peregrine falcon pair to the sensitive species was most likely the cause for the abandonment of the nests. The peregrine falcons in this case were removed and relocated to a cliff side in Oregon but it is not known if the peregrine falcons returned to the original area (Pagel, Patton, \& Latta, 2010).

Certain peregrine falcons have been known to specialize in a small selection of prey species in disproportion to its availability. This could potentially result in significant impacts to sensitive prey species under management, if they are the prey choice (Long \& Roanoke, 2009). Citizen scientists (Dennhardt, Duerr, Brandes, \& Katzner, 2015) who 
have observed year-long behavior of peregrine falcons, noted in different locations in the Bay Area the birds target different bird prey species. For example, the coastal peregrine falcons of Monterey Bay, Santa Cruz, Eden Landing, and Alviso salt ponds are known to prey on gulls and shorebirds while peregrine falcons inland in the San Jose and San Francisco downtown areas pursue pigeons, doves and song birds. Some inland resident pairs, however, do seek, out shorebirds during breeding seasons (G. Stewart, personal communication, September, 2008). This can likely be explained as a matter of simple proximity: the prey that is readily available to a hunting peregrine falcon. Hence, relocation plans for a peregrine falcon that is perceived to be a repeated threat to colonies of sensitive shorebird species, should consider specific elements pertaining to the bird being considered for relocation, its prey preference and availability, and if the new habitat can support the species. Resource managers need to carefully weigh the benefits of relocation with its associated costs in comparison to the benefits of habitat restoration for both predator and prey species.

Some scientific literature does conclude that removal or relocation of predators contributes to the reproductive success of declining prey populations (Smith et al., 2010). However, in other studies, such as that conducted by Holt, Davies, Tyler, and Staddon (2008) it was determined that invasive mammalian predators had a greater impact and effected change in population numbers more negatively than by avian predators. Also, an avian predator removed from the vicinity of a prey population that was affected by its predation was quickly replaced by a mesopredator. Each prey species may react uniquely to predation, which could differ based on behavioral traits and population status. A large 
population of prey species can be affected by a perceived risk of predation even after the actual predator is gone from that habitat (Cresswell, 2011). Hence, relocation in such instances may not necessarily boost back prey populations with increase in numbers. Côté and Sutherland (1997) determined that the effectiveness of predator removal from a habitat created a void in that ecosystem but may not have contributed to the overall significant increase in the breeding bird success. In this study, it was found that thousands of prey species kept away from a perfectly good breeding habitat due to a perceived fear of possible threat.

Despite significant concerns about proximity to sensitive species, peregrine falcons also have some positive influence on avian species. In a study (Paine, Wootton, \& Boersma, 1990) conducted on Tatoosh island in the State of Washington, the peregrine falcon, although a specialized hunter that predominantly preys on avian species, turned out to be beneficial for larger seabirds such as some gulls (Laridae), Common murres (Uria aalge) and Pelagic cormorants (Phalacrocorax pelagicus) that were negatively impacted by crows (Corvus) on this island. Specifically, the falcons actively sought out the crows and kept other predatory birds such as eagles, hawks, and ravens (Corvus corax) away from the cliff sites where the large shorebirds and the peregrine falcons were nesting. Another example of peregrine falcon benefits to other species was found when a pair of nesting peregrine falcons indirectly served as deterrents to bald eagles and Glaucous-winged Gulls (Larus glaucescens) that preyed upon several eggs and chicks of Common murres and Pelagic cormorants in British Columbia. Breeding pairs of peregrine falcons are aggressive defenders of their territory (Dekker, Dekker, Christie, \& 
Ydenberg, 2011) and hence they kept all potential threats away and therefore inadvertently helped thousands of these seabirds thrive in that area (Hipfner, Morrison, \& Darvill, 2011).

Research studies such as these show that it is important to consider the dynamics of a key indicator species such as the peregrine falcon's influence on not just one species in the ecosystem targeted as prey, but several species in that ecosystem and how it influences each other due to the presence of a top predator in that habitat. Hence, drastic measures to remove or translocate peregrine falcons without consideration of several such factors could impact the ecosystem in unexpected ways. Also, according to one research team, most relocations have been proven to be futile (Garrott et al., 1993).

\section{Geographic Information Systems (GIS) in Ecology}

GIS is an invaluable tool to study habitat analysis for species as well as the spatial dimensions of inter-species dynamics. In the field of ecology and conservation biology, obtaining comprehensive data for elusive species can be difficult due to the extended home ranges of the species across state lines and/or management of time and budget constraints (Carter et al., 2009). GIS is an essential tool (López-López, García-Ripollés, Soutullo, Cadahía, \& Urios, 2007) that allows for analysis of available disparate data at both spatial and temporal scales and for extrapolation using models. Geospatial analysis of environmental attributes represented as digital, overlaid map layers in conjunction with the spatial distribution of the species under study can be conducted using GIS technology. Furthermore, with this information at hand, the attributes tied to the map layers can be used to conduct species distribution predictive modeling through its range (Bustamante \& 
Seoane, 2004). GIS technology can help conservation planners make informed decisions based on multi-scaled analysis of the digital data (Carter et al., 2009) and can develop insights into future suitable habitats (Isaac et al., 2008; Mathieu, Seddon, \& Leiendecker, 2006).

\section{Similar Research Methods}

GIS technology was used in research on habitat spatial analysis that aided in predicting the likelihood of target species to inhabit particular sites (Isaac et al., 2008). In another study, GIS was used to generate random data points and digital layers of environmental parameters for each Northern Spotted owl (Strix occidentalis) nest location, which supported the development of input metrics (Stralberg et al., 2009). In another study of peregrine falcons and ravens, Jenkins and Zyl (2005) plotted their study sites in GIS at a scale of 1:50000 to incorporate large-scale land cover and terrain characteristics of their study area; the team also employed spatially-enabled statistical analysis using Nearest Neighbor Distance (NND) to measure locational relationships between inter- and intra-specific sites.

Isaac, Cooke, Simmons, and Hogan (2008) used GIS to predict the breeding sites of the powerful owl (Ninox strenua) in urban Melbourne, Australia. In two other studies of Eleonora's falcon (Falco eleonorae) and the peregrine falcon (Falco peregrinus tundrius) respectively, GIS was used in model predictions to determine proportions of topological features such as vegetation coverage and urban features as a function of nesting territory within the study area (Kassara et al., 2012; L’Hérault, Franke, Lecomte, Alogut, \& Bêty, 2013). Dykstra, Simon, Daniel, and Hays (2012) conducted a habitat assessment study 
using GIS to map suburban Barred owl (Strix varia) and Red-shouldered hawk (Buteo lineatus) nest locations with GPS-derived coordinates that were then overlaid on digital land cover dataset obtained from the National Land Cover Database (NLCD) and National Hydrography Datasets (NHD).

Two research studies (Booms, Huettmann, \& Schempf, 2010; Mathieu et al., 2006) used a base Digital Elevation Model (DEM) to derive the terrain aspect, elevation and slope map layers for their research. A buffer (a user-defined distance) was generated by the researchers based on extent of territory around each Gyrfalcon (Falco rusticolus) and eastern New Zealand falcon (Falco novaeseelandiae) nest site respectively in each of the studies to evaluate the influence of the environmental variables. Gibson, Wilson, Cahill, and Hill (2004) used GIS-based raster layers in the habitat assessment of the rufous bristlebird (Dasyornis broadbenti), incorporating distances from nesting sites to waterways using hydrology datasets and DEM data with 20 m DEM resolution.

A combination of biotic and abiotic attributes was considered in a predictive habitat suitability model study using GIS conducted by Fernandez and Gurrutxaga (2010) for several species of raptors including the peregrine falcon. Both Jenkins (2000a) and Kassara, Dimalexis, Fric, Karris, Barboutis, and Sfenthourakis (2012) looked at prevailing wind direction as a climate attribute which was a crucial factor during the breeding season of the Eleonora's falcon. While Jenkins (2000a) determined that wind direction affected the nest site orientation based on the rainfall received, in the other study, the average wind direction was calculated for the months when strong winds were prevalent in the area of study. 
Stout and Rosenfield (2010) found that understanding the distance between neighboring sites of urban Coopers hawks (Accipiter cooperii) and its dispersion patterns provided insight into the population distribution of the species spatially, preference and utilization of habitat, its carrying capacity, and its density. A red-backed shrike (Lanius collurio) study (Brambilla et al., 2009) adopted a two-step model process beginning with obtaining landscape-level information as digital data layers within GIS. Then, 1-ha buffers were created around each observed and random points on the map and values for land cover, vegetation, mean elevation, slope, length and orientation within these buffers were calculated. This result was then extended to a regional level to map the spatial distribution of approximate suitable habitats for the species and a second model obtained on-site species-specific information. A combination of both models gave the most accurate habitat suitability information for their target species with the first GIS-based model contributing to identification of the prime habitats for the species and the second model helping in related conservation planning efforts.

In a study of Lanner falcon (Falco biarmicus) and peregrine falcon nest sites at 37 locations (Amato et al., 2014), a buffer of $2.9 \mathrm{~km}$ was created around each nest site using GIS. Site characteristics of aspect, slope, and altitude of the cell were analyzed using DEM data for the terrain. Quarterly means of precipitation, solar radiation and temperature from world climate (Fick \& Hijmans, 2017) datasets were also incorporated into the analysis.

Coulton, Virgl, and English (2013) used Principal Component Analysis (PCA) to look at eigenvalues and Principal Component (PC) scores to draw information on how 
much variance each attribute contributed with regard to nest locations of the peregrine falcon and Gyrfalcon. In a study of the middle spotted woodpecker (Dendrocopos medius), highly correlated environmental variables were used as factor scores in a predictive model and the change and response between the variables and the predicted values were observed (Stachura-Skierczyńska \& Kosiński, 2014). Bonn and Gaston (2005) looked at environmental categories, climate, topography, vegetation, and energy levels pertaining to species distribution. A linear relationship between species richness and productivity with two variables, mean annual precipitation and energy, was determined. Ozialak, Lacki, and Carter (2005) in their research to evaluate habitats, categorized and reclassified land-use into four categories (agricultural, forest, developed and open water), which they found to be applicable to the analysis of peregrine falcon ecology.

The productivity of nesting peregrine falcons in the northeastern United States was compared between urban and rural habitats (Gahbauer et al., 2015) for characteristics such as overhead protection, man-made nest boxes (Cade et al., 1996) and direction of nest. In general, they found elements of overhead protection and provision of man-made nest boxes increased the productivity of nests. Hickey (1942) found that provisioning of nesting trays with substrate, encouraged peregrine falcons to stay at a given site that otherwise might have been rejected due to a lack of nesting substrate.

Productivity of nesting sites in quarries and building structures were higher than on bridges and power transmission towers in marshes. Wightman and Fuller (2006) studied the affinity of peregrine falcons to cliffs and if certain characteristics of the eyries 
qualified to be a more productive habitat. They found that at the natural cliff sites, elements such as deep ledges, higher cliffs with open views of the surroundings, lower precipitation, and fewer and more distant neighbors defined high quality nesting habitats.

In a comparative study (Jenkins, 2000b) in South Africa that looked at breeding success of peregrine and Lanner falcons, it was found that peregrine falcons experienced breeding success in subsequent years of heavy rainfall which increased water levels and prey availability. But in a given year, annual productivity correlated positively with decreased precipitation or a dry season. This was because of the increased success in the survival of nestlings in higher temperatures, which allowed for better fledge success. It was concluded that breeding success for peregrine falcons was strongly related to physical environmental attributes and its effect on prey abundance. Jenkins (2000) found that peregrine falcons hunting from higher elevations were more successful and experienced higher reproductive rates, lifetime success, and productivity of peregrine falcon nests was positively correlated to elevation (Gahbauer et al., 2015).

Ydenberg, Butler, Lank, Smith, and Ireland (2004) determined that the fear factor of the presence of predators such as the peregrine falcon left a far reaching adverse effect on the western sandpiper (Calidris mauri) prey species affecting physiology, migratory inclinations, overall behavior and conditioning. This could potentially affect various ecological communities and not just one species. Some shorebirds such as the semipalmated sandpiper (Calidris pusilla) developed tactics to avoid raptor predation either by crouching or hiding in vegetation for cover or took to the air in defensive, dense flocks in attempts to outsmart its predator (Dekker, 2009). In another study, it was 
determined predation risks experienced by Audouin's gulls that nested in colonies in a denser and smaller area were relatively lower than those that were spread out on the terrain (Oro, 1996). The concentration of the colony more so than the colony size, dictated the predation risks. Evolutionary selection could both favor the prey groups to congregate in denser and smaller groups to avoid aerial predation and the predators to evolve to tackle these dense prey groups to their advantage (Oro 1996).

In two separate studies, peregrine falcons sought out larger shorebirds when abundant which resulted in more successful fledglings and prey smaller than $50 \mathrm{~g}$ was rarely selected (Dawson, Mossop, \& Boukall, 2011; Ritchie \& Shook, 2011). Dawson, Mossop, and Boukall (2011) found that peregrine falcons along the Yukon River in Canada were selective as well in terms of prey choices and rarely chose birds smaller than $50 \mathrm{~g}$ and larger than $1000 \mathrm{~g}$. 


\section{Objectives}

The urban peregrine falcon population is rapidly growing around the world and the birds are making their homes in urbanized areas, amidst cityscapes and other man-made structures (Cade et al., 1996). As they adapt to anthropogenic settings, peregrine falcons have established breeding populations in urban environments and bird numbers have increased significantly. Hence, research is needed to assess the potential for continued population growth, habitat qualities that are likely to support that growth, and impacts of peregrine falcons on sensitive species in urban settings. Also, the features that urban peregrine falcons seek in breeding locations are not well characterized. Information on breeding site selection can help wildlife managers understand if peregrine falcon populations will continue to grow and whether falcon-nesting locations may affect sensitive prey species. The San Francisco Bay Area is an ideal habitat to explore these issues.

In this study, the factors that peregrine falcons may be seeking in nesting locations in the highly urbanized San Francisco Bay Area were examined. One important facet of the work was to assess whether peregrine falcons may be attracted to nest sites near two federally listed species in the Bay Area, the California least tern and the western snowy plover. Spatial analysis can help managers protect and manage the growing peregrine falcon population by showing availability of viable habitat and where areas with prey species may be negatively impacted by peregrine falcons. Understanding the features or habitat qualities that attract peregrine falcons may even help in design of urban green features to attract or repel nesting birds. 
To provide insight into the question of important factors in nest site selection of urban peregrine falcons, the following research questions and hypotheses were addressed:

\section{Research Questions}

Q1: Did the existing pattern of peregrine falcon nesting sites exhibit spatially significant clustering? If so, where was the clustering?

Q2: What are the common qualities that describe the locations of these nests, including the relationship between peregrine falcon nests and federally listed species locations?

\section{Hypotheses}

$\mathrm{H}_{0} 1$ : There is no significant difference in nest site qualities between peregrine falcon nests located on anthropogenic versus natural features.

$\mathrm{H}_{0} 2$ : There is no significant difference between the land cover categories with respect to the natural and anthropogenic nest locations.

Q3: Based on these qualities, how can the distribution of the breeding peregrine falcon population in the San Francisco Bay Area be described? 


\section{Methods}

\section{Study Area}

The study area was the San Francisco Bay Area, California $\left(37.8272^{\circ} \mathrm{N}\right.$, $122.2913^{\circ} \mathrm{W}$ ) and included the counties of Alameda, Contra Costa, Marin, San

Francisco, San Mateo, Santa Clara, Sonoma, Napa, and Solano and extended as far as Santa Cruz County in the south. The study area extended about $12,000 \mathrm{~km}^{2}$ from the northern end of Marin County to Santa Cruz County in the south (Figure 9). The San Francisco Bay Area enjoys a Mediterranean climate with rainy winters and dry summers. The coastal areas are inundated by fog usually in the summer season (Thorne, Santos, \& Bjorkman, 2013). 


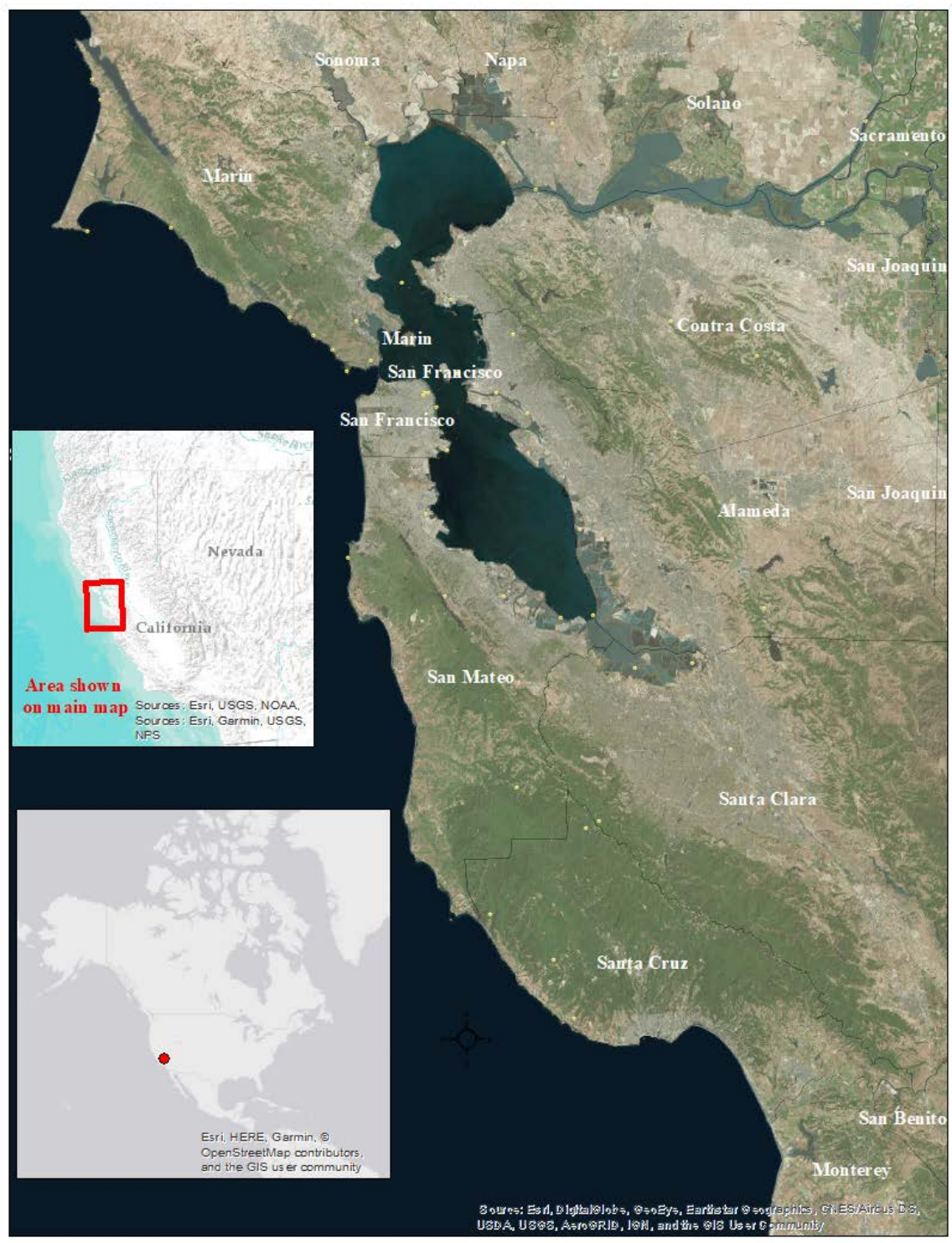

Figure 9. Study area - San Francisco Bay Area, California (Map was created in ArcMap for ArcGIS Desktop 10.5.1).

The San Francisco Bay Area is an example of an estuary responding to natural and anthropogenic forces with ever-changing interface influences of climate, salt and fresh water influx (Cloern \& Jassby, 2012). As of 2010, the human population in the San Francisco Bay Area exceeded 7 million (Maizlish et al., 2013). The estuarine-coastal ecosystem is also highly productive due to its dynamic nature (Watson \& Byrne, 
2009). The biogeochemical changes support a nourishing environment for fish and other invertebrates. This in turn attracts a diverse group of avian populations from songbirds to shorebirds. This estuary is also the prime wintering grounds for at least $30 \%$ of individual shorebird populations and diving duck populations that migrate via the Pacific Flyway (Takekawa, Lu, \& Pratt, 2001). According to Okamoto, Rubissow, and Wong (2011), approximately one million shorebirds may traverse through the San Francisco Bay Area in a single day during peak migrations. The region supports a number of endemic species both on the 1.2 million acres of open spaces/natural preserves and in urbanized areas. The region is also a well-known biodiversity hotspot (Rissman \& Merenlender, 2008).

California has large variability in habitat from coastal mountains to deserts, elevation, microclimates, vegetation, and avian species. For the species at the center of this study, the peregrine falcon, its prime habitat is the aerial space and it relies on the terrestrial habitat only for roosting and breeding (Burnham \& Cade, 2003). Hence, dramatic changes in human populations or the terrestrial environments may only indirectly affect the peregrine falcon to the extent that they affect the avian prey species that rely on the terrestrial habitats. Hence, where there is an abundance of avian species, peregrine falcons will resort to breeding on any man-made structures or even ground (Boettcher \& Mojica, 2016) with easy access to its prey (Burnham \& Cade, 2003).

The peregrine falcon study population considered in this research was the San Francisco Bay Area southern subpopulation, a subset of the larger core populations in 
California which include the northern interior and the mid-southern coast (Wootton \& Bell, 1992). However, due to the abundance of peregrine falcons everywhere throughout suitable habitat, this distinction probably no longer exists. This subpopulation comprises coastal natural and interior urban peregrine populations of California (Kauffman et al., 2004). The peregrine falcons of the San Francisco Bay Area population are year-round residents and the breeding season spans from January to July. The breeding habitat includes natural cliffs, beaches, tall buildings, bridges, smokestacks, power transmission towers, and cranes. The foraging areas include beaches, highly urbanized areas such as city centers, salt ponds, and marshlands.

\section{Data Sources}

The study was conducted on known peregrine falcon nest sites around the San Francisco Bay Area recorded between 2009 and 2013. The Santa Cruz Predatory Bird Research Group (SCPBRG), which tracks all known peregrine falcon nest locations in the San Francisco and Monterey Bay Areas, provided the locations of the nests used in this study as latitude and longitudinal coordinates for each location. The list of management sites for the western snowy plover was obtained from the San Francisco Bay Bird Observatory (SFBBO) (Pearl, Tokatlian, Scullen, Strong, \& Krause, 2017). One of the two known California least tern colonies in the San Francisco Bay Area, was considered in this study (J. Albertson, personal communication, September 2015). Based on previous research, ten environmental attributes important to raptors with the data sources for these attributes as listed in Table 1 were used in this study. 
Table 1.

List of Attributes Used to Assess Nest Site Selection

\begin{tabular}{|c|c|c|}
\hline Attribute & Data Type & Source \\
\hline $\begin{array}{l}\text { Elevation (Height of nest) } \\
\text { (Brambilla, Bassi, Ceci, \& } \\
\text { Rubolini, 2010; Ritchie \& } \\
\text { Shook, 2011; Sergio, Rizzolli, } \\
\text { Marchesi, \& Pedrini, 2004; } \\
\text { Wakamiya \& Roy, 2009; } \\
\text { Wightman \& Fuller, 2006) }\end{array}$ & Continuous & $\begin{array}{l}\text { The Light Detection and } \\
\text { Ranging (LIDAR) } \\
\text { Remote Sensing Data. } \\
\text { Google Earth Pro 7.3.1/ } \\
\text { ArcGIS 10.5.1 } \\
\text { topographic basemap }\end{array}$ \\
\hline $\begin{array}{l}\text { Slope } \\
\text { (Amici et al., 2015; } \\
\text { Bustamante \& Seoane, 2004; } \\
\text { Fernandez \& Gurrutxaga, 2010; } \\
\text { Mateo-Tomás \& Olea, 2010; } \\
\text { Stralberg et al., 2009;) }\end{array}$ & Continuous & $\begin{array}{l}\text { ArcGIS 10.5.1 - Slope } \\
\text { tool }\end{array}$ \\
\hline $\begin{array}{l}\text { Wind Speed } \\
\text { (Brambilla et al., 2010; Jenkins, } \\
\text { 2000a; Kassara et al., 2012; } \\
\text { Mathieu et al., 2006; Meineri, } \\
\text { Deville, Grémillet, Gauthier- } \\
\text { Clerc, \& Béchet, 2015) }\end{array}$ & Continuous & World Climate Dataset \\
\hline $\begin{array}{l}\text { Average Solar Radiation } \\
\text { (Amato et al., 2014; Amici et } \\
\text { al., 2015; Gibson et al., 2004; } \\
\text { Tovar-Pescador et al., 2006) }\end{array}$ & Continuous & World Climate Dataset \\
\hline $\begin{array}{l}\text { Nearest Neighbor Distance } \\
\text { (NND) } \\
\text { (Fernandez \& Gurrutxaga, 2010; } \\
\text { Ritchie \& Shook, 2011; Sergio } \\
\text { et al., 2004; Stout \& Rosenfield, } \\
\text { 2010; Wightman \& Fuller, 2005, } \\
\text { 2006) }\end{array}$ & Continuous & ArcGIS 10.5.1- Near tool \\
\hline $\begin{array}{l}\text { Average Precipitation } \\
\text { (January-July) (Booms et al., } \\
\text { 2010; Fernandez \& Gurrutxaga, } \\
\text { 2010; Mateo-Tomás \& Olea, } \\
\text { 2010; Rejt, 2001;) }\end{array}$ & Continuous & World Climate Dataset \\
\hline $\begin{array}{l}\text { Distance to Federally Listed } \\
\text { Species (Larson et al., 1994; } \\
\text { Pearl, 2015; Tokatlian, 2017; } \\
\text { Hornaday et al., 2007) }\end{array}$ & Continuous & ArcGIS Near tool \\
\hline
\end{tabular}




\begin{tabular}{|c|c|c|}
\hline $\begin{array}{l}\text { Distance to nearest waterway } \\
\text { (coastline/stream/river/creek) } \\
\text { (Gibson et al., 2004; Kassara et } \\
\text { al., 2012; Mathieu et al., 2006; } \\
\text { Shabani et al., 2009; Stralberg et } \\
\text { al., 2009) }\end{array}$ & Continuous & $\begin{array}{l}\text { ArcGIS Near tool; } \\
\text { Hydrography dataset }\end{array}$ \\
\hline $\begin{array}{l}\text { Average Temperature } \\
\text { (January-July) (Amici et al., } \\
\text { 2015; Booms et al., 2010; } \\
\text { Guisan \& Zimmermann, 2000; } \\
\text { López-López et al., 2007) }\end{array}$ & Continuous & World Climate Dataset \\
\hline $\begin{array}{l}\text { Land Cover (Bustamante \& } \\
\text { Seoane, 2004; Rullman \& } \\
\text { Marzluff, 2014; Shabani et } \\
\text { al., 2009). }\end{array}$ & Categorical & NLCD 2011 \\
\hline
\end{tabular}

Software used in the analysis included Spatial Analyst extension for ESRI ArcGIS Desktop 10.5.1, IBM SPSS Statistics Version 24, Microsoft Excel 64-bit in Microsoft Office Professional Plus 2016, Google Earth Pro 7.3.1 for Microsoft Windows 6.2, RStudio V1.1.419/R statistical computing software version 3.4.3. GIS data portals were used to collect individual data sets to prepare layered maps showing environmental factors that define each nest location. The data portals used were the NLCD 2001 (Homer et al., 2015), the National Map (U.S. Department of the Interior | U.S. Geological Survey, 2018) and World Climate (Fick \& Hijmans, 2017).

\section{Study Design}

The choice of the ten environmental attributes (Table 1) was based on similar research methods (as described earlier) to be of most importance to the species under study. The nesting sites and the environmental attributes or variables in this study were brought in as digital layers into ArcMap (ArcGIS 10.5.1). Each environmental 
attribute layer in association with the nesting sites layer was examined and geoprocessed as explained later in this section. Descriptive and inferential statistics, and Principal Component Analysis were performed on the resulting GIS attribute layers to identify key environmental factors, its statistical significance and key factors that explained the most variance in the data.

Nest sites were assumed to be within a $30.48 \mathrm{~m}$ buffer around the given coordinates for each nest to evaluate the elevation and slope attributes. The buffer compensated for the lack of precise coordinates of nesting locations and the $30.48 \mathrm{~m}$ radius from these coordinates provided a large enough area within which to perform GIS-based zonal statistics. A $2.41 \mathrm{~km}$ buffer around each nest site was also used to analyze the climate attributes. This distance was based on a study in Greenland where it was found that the minimum territorial distance between neighboring peregrine falcon sites was estimated to be $2 \mathrm{~km}$ (Wightman \& Fuller, 2005, 2006).

Hence, based on the nature of nest locations in the San Francisco Bay Area where an average distance of $4.55 \mathrm{~km}$ between nest locations was reported (Stewart, 2016), the $2.41 \mathrm{~km}$ buffer was considered to ensure specificity of nests and reduce chances of overlapping values. The latitude and longitude coordinates in degrees, minutes and seconds for each site location were converted to decimal degrees using an online converter (Hedges, 2003).

The choice of weather-related datasets used in this research was significantly influenced by research on Gyrfalcons (Booms et al., 2010) where the effects of weather elements (datasets obtained from worldclim.org) on the breeding cycle was 
considered in the choice of attribute. The influence of precipitation, temperature, solar radiation and wind speed on the breeding time frame for the peregrine falcons in the San Francisco Bay Area was considered in this research. The breeding season is from January through July for most nest sites with slight variations in time between sites but the breeding peregrines in this study area are most influenced by these environmental factors in these seven months. Another study of breeding peregrine falcons at Biscay, Spain (Zabala \& Zuberogoitia, 2014) also reported a similar breeding time frame. Hence, the averages for temperature, precipitation, solar radiation and wind speed attribute were calculated for this seven-month period.

\section{Data Analysis}

The ten topographic factors (table 1) were considered as a function of each nesting territory within the study area and its proportion of influence was examined using the independent samples $t$ test for equality of means, Pearson Chi-Square test of independence for the categorical attribute land cover, and PCA as appropriate to address the research questions and hypotheses.

As a starting point for an analysis of spatial relationships between nest sites including answering the first research question about spatial distribution of the sites, "the Average Nearest Neighbor” tool in ArcGIS application, ArcMap-Spatial Statistics toolset was used. The purpose of this tool is to indicate the presence or absence of clustering in the data. If the nest sites exhibited significant spatial clustering, this would signal the presence of an underlying geographic phenomenon causing the clustering and therefore worthy of further study. If the nest sites exhibited randomness, this would signal the 
absence of an underlying geographic phenomenon driving the selection of nest sites and the species might be unaffected or unimpeded by the activities of proximate peregrine falcons.

To answer the research questions of common qualities that describe the nest locations and to test the null hypotheses (1) SPSS-Descriptive statistics was used to obtain the minimum, maximum and the mean for all the attributes defining the nesting locations. This information helped to understand how each attribute affected the nesting locations and facilitated in drawing conclusions as to the factors of highest relevance to the species in choosing the nest location. (2) SPSS-Inferential statistics (Independent samples $t$ test for equality of means and the Pearson Chi-Square test of independence for land cover) were used to differentiate between values for the natural and anthropogenic sites for each attribute to understand its influence on the nesting location. (3) PCA was used to determine which attributes were most important for the breeding sites and which ones could be filtered out based on its importance.

Mapping nest locations and related buffers. The latitude and longitudinal coordinates for each nest location were converted to decimal degrees using the formula, Decimal Degrees $=$ Degrees + minutes $/ 60+$ seconds/3600. In ArcGIS 10.5.1, using ArcMap, the points were georeferenced to spatial locations and converted to a point feature class (a term used for a vector data layer in ArcMap). The $30.48 \mathrm{~m}$ and the 2.41 km buffers were the next two feature classes that were established as layers in ArcMap. These were then used as the foundation layers on which all other environmental attribute layers were stratified and analysis was conducted. The projected coordinate system for 
all layers was NAD_1983_California_Teale_Albers_FtUS, which is the appropriate choice for a California study area that covers multiple regions. Also, the study area around all the nest locations was defined in ArcMap using the "Minimum Bounding Geometry” tool to create a polygon encompassing all the sites. This enabled huge raster datasets to be “clipped” to the study area thereby minimizing processing latency. In order to determine the optimal cell size to use for the raster analysis, the cell size used for each of the attribute raster was considered. Then, the cell's length and width was measured using the "Measure" tool in ArcMap, to get the most common cell size. Also the environmental datasets from World Climate and National Map were derived at the original cell size resolution of 9x9 m, hence this was adopted for all layers to maintain uniformity.

Elevation of nesting sites. The estimation of the elevation of each nest site was done using a combination of LIDAR, DEM and topographic basemaps. The elevation attribute in this study was quite specific to each location. For the locations on bridges, taking the maximum elevation of the bridge was not universally applicable for all bridge nest locations. On some bridges, peregrine falcons nest on top of the tower but in many other cases, they tend to nest on the underside of the bridge. Mean height of the bridge is a conservative estimate because it takes into account the undulations of the bridge. The closest elevation value between the mean and the maximum elevation was then chosen depending on that specific nest site on that bridge. Also, for some of the power transmission tower sites, the LIDAR dataset was absent and, in those cases the standard power transmission tower height for that specific area was used. For the sites on 
buildings, smokestacks, and natural cliffs a combination of values from LIDAR dataset, Google Earth- measurement tool, and topographic basemaps in ArcMap were considered for the approximate closest value possible for that site.

DEM raster files represent the topographic elevation of the terrain above sea level in meters. The National Elevation Dataset (NED) from USGS was a 1/3 arc-second or approximately $10 \mathrm{~m}$ resolution DEM (10x10 m). The $10 \mathrm{~m}$ DEM was re-sampled to conform to the chosen cell size of 9x9 m, projected and clipped to the study area using the Spatial Analyst tool, "Extract by Mask" for standardization purposes and to be used properly with other datasets such as slope. For the man-made structure sites, it was essential to use LIDAR datasets to measure the elevation since LIDAR not only measures the topographic elevation of the terrain above sea level, but it also includes the structure on it. LIDAR files are in binary format and are often available as a LAS dataset (ESRI, 2016). Specifically, the LIDAR data was used to estimate the elevations of nest sites. The LAS files were then converted to raster using the "LAS to Raster" tool and projected to conform to the $9 \times 9 \mathrm{~m}$ cell size set for this project. The resulting rasters were clipped to the $30.48 \mathrm{~m}$ nesting site buffer using the "Extract by Mask" tool (Figure 10). "Zonal Statistics” tool in ArcGIS Spatial Analyst Extension was used to calculate the average and maximum elevation within the $30.48 \mathrm{~m}$ nesting site buffer. 


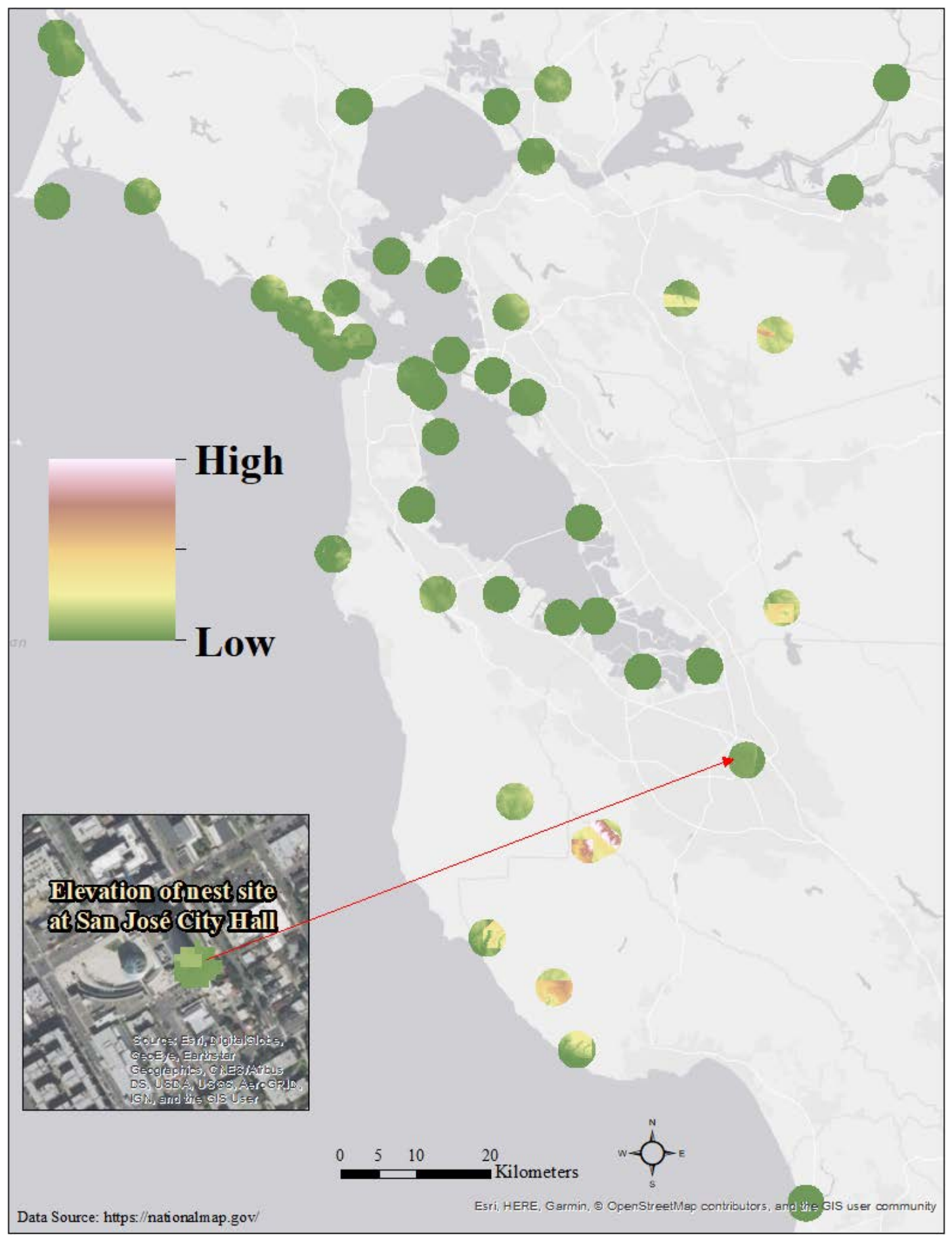

Figure 10. Elevation within the $30.48 \mathrm{~m}$ buffer at each peregrine falcon nest location (Map was created in ArcMap, ArcGIS Desktop 10.5.1). 
Slope. The slope at each nest location was determined using the "Slope" tool in the Spatial Analyst extension package in ArcGIS. This tool calculates the slope grid map layer from the $10 \mathrm{~m}$ resolution DEM. The resulting raster was then projected and resampled to the selected coordinate system of NAD_1983_California_Teale_Albers_FtUS with 9x9 m cell size. In this study, slope measurement pertains to the underlying terrain and not the structure on it. For example, one prominent nest site is located towards the top of the city hall for the city of San Jose. Since the building façade essentially represents a 100\% slope, the slope of the underlying land upon which the building resides was calculated). The slope raster was clipped to the study area within the 30.48 m buffer and then “Zonal Statistics” tool in ArcGIS Spatial Analyst Extension was used to calculate the average slope (Figure 11). 


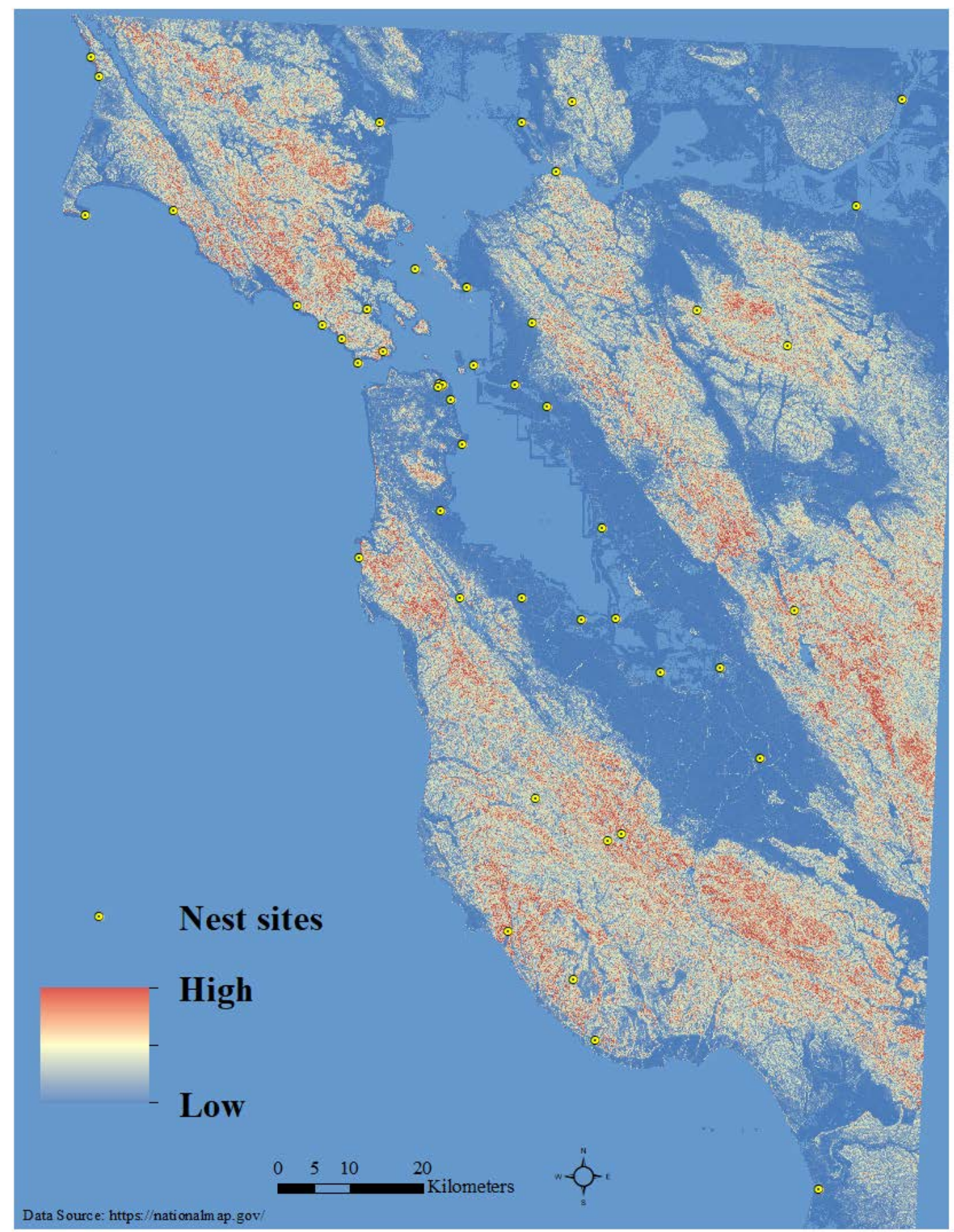

Figure 11. Percent slope for the study area (Map was created in ArcMap, ArcGIS Desktop 10.5.1). 
Average wind speed. The wind speed dataset measured in units of ms-1 at a spatial resolution of $30 \mathrm{~s}$ or approximately $1 \mathrm{~km} 2$ was obtained from world climate (Fick \& Hijmans, 2017) dataset. The datasets were clipped to the study area using the "Extract by Mask” tool and the average wind speed from January-July was calculated in ArcMap using the "Raster Calculator" tool. The resulting raster was projected and resampled to the selected coordinate system of NAD_1983_California_Teale_Albers_FtUS with 9x9 m cell size (Figure 12). "Zonal Statistics" tool was used to calculate the average wind speed within the $2.41 \mathrm{~km}$ buffer instead of the $30.48 \mathrm{~m}$ buffer. This was because within the $30.48 \mathrm{~m}$ buffer, the wind speed dataset was absent for some of the sites and the buffer was not large enough to include the next closest cell with values. Hence, the $2.41 \mathrm{~km}$ buffer was used for the zonal statistics for this attribute. 


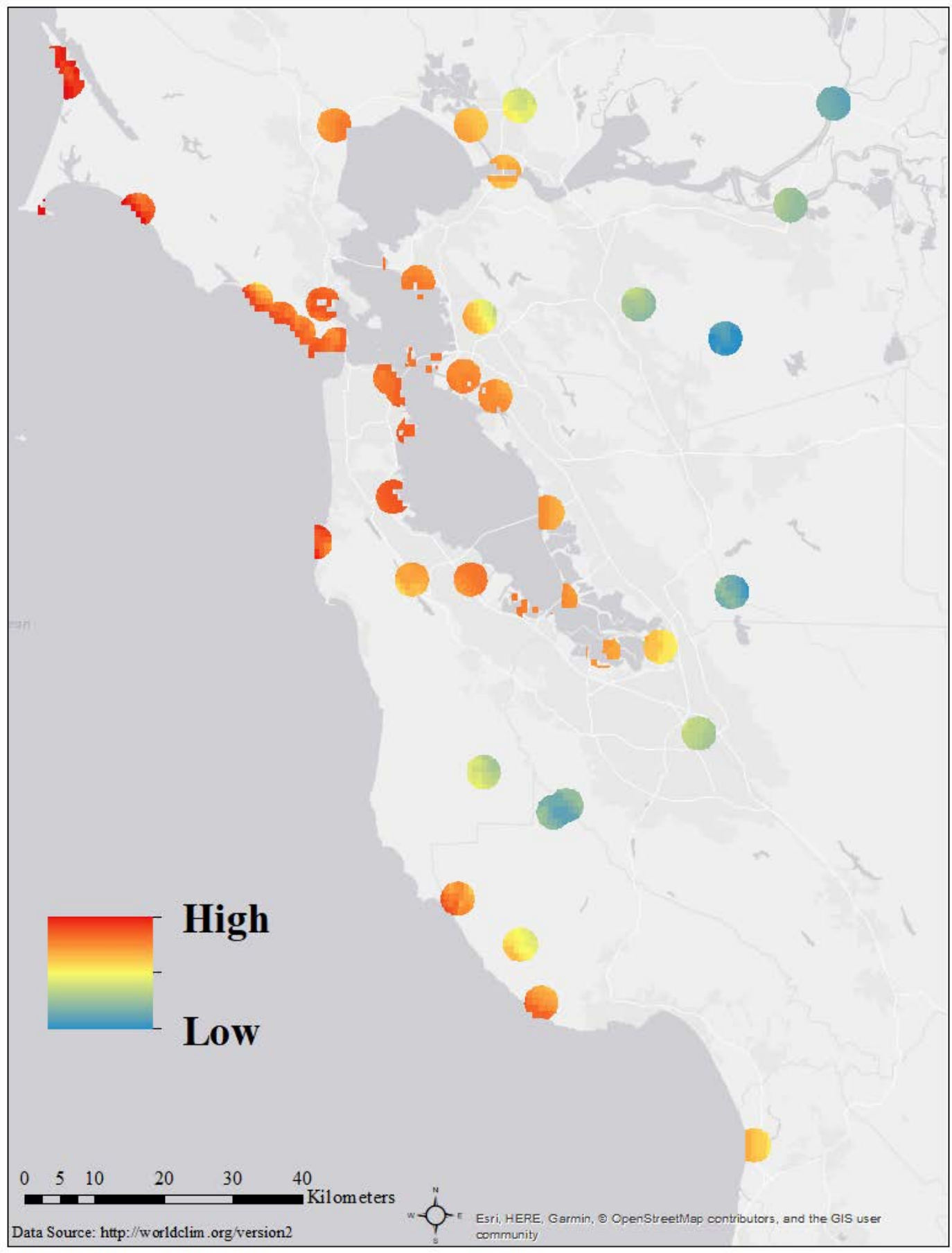

Figure 12. Wind speed within the $2.41 \mathrm{~km}$ buffer at each peregrine falcon nest location (Map was created in ArcMap, ArcGIS Desktop 10.5.1). 
Average solar radiation. The solar radiation dataset in units of $\mathrm{KJ} \mathrm{m}-2$ day-1 at a spatial resolution of $30 \mathrm{~s}$ or approximately $1 \mathrm{~km} 2$ was also obtained from the world climate dataset. The datasets were clipped to the study area using the "Extract by Mask" tool and the average solar radiation from January - July was calculated in ArcMap using the "Raster Calculator.” The resulting raster was projected and resampled to the selected coordinate system of NAD_1983_California_Teale_Albers_FtUS with 9x9 m cell size. “Zonal Statistics” tool was used to calculate the average solar radiation within the 2.41 km buffer instead of the $30.48 \mathrm{~m}$ buffer. This was because within the $30.48 \mathrm{~m}$ buffer, the solar radiation dataset was absent for some of the sites and the buffer was not large enough to include the next closest cell with values. Hence, the $2.41 \mathrm{~km}$ buffer was used for the zonal statistics for this attribute (Figure 13). 


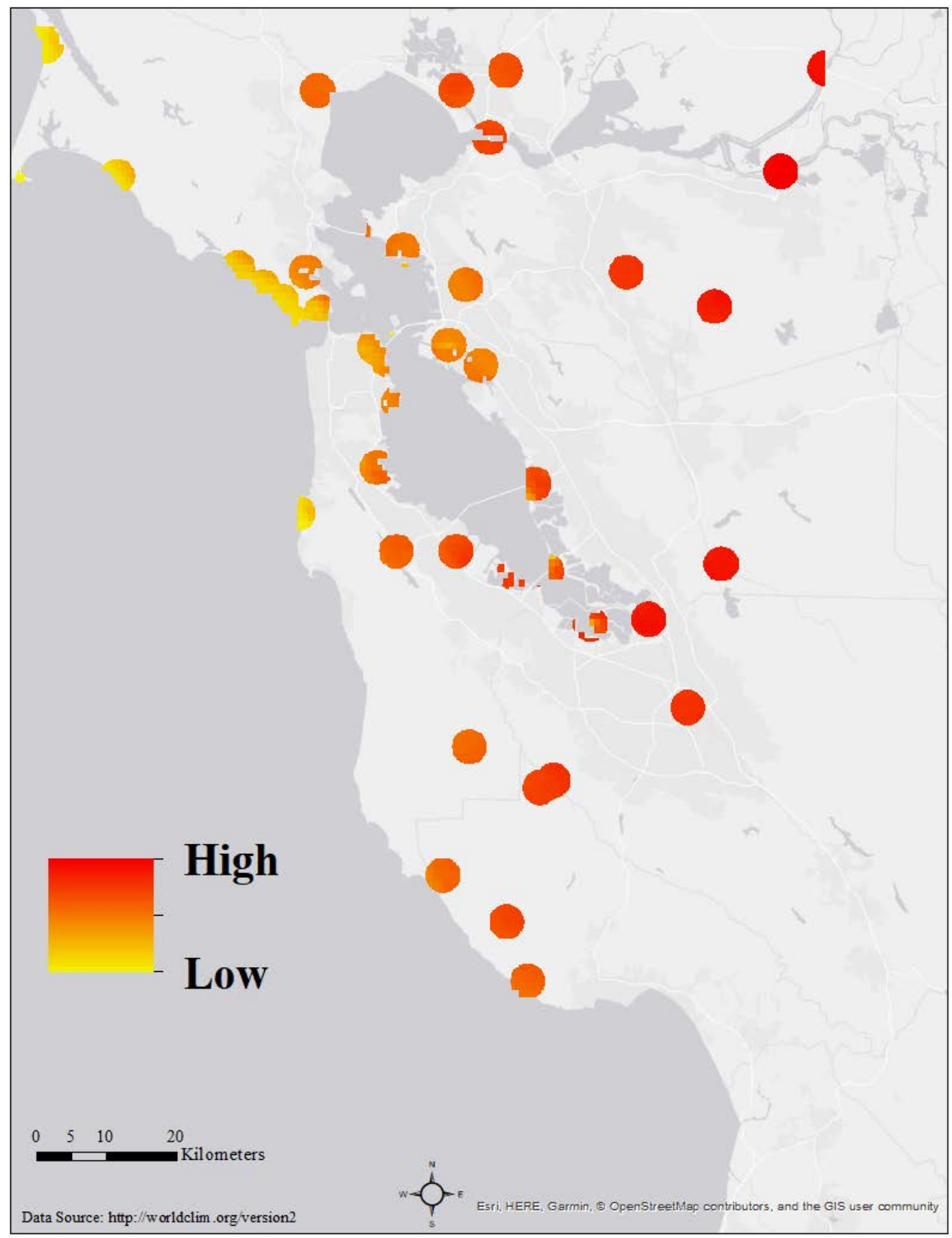

Figure 13. Solar radiation within the $2.41 \mathrm{~km}$ buffer at each peregrine falcon nest location (Map was created in ArcMap, ArcGIS Desktop 10.5.1). 
Nearest Neighbor Distance (NND) between nest sites. The distance between each nest location and its next closest neighbor was calculated using the "Near Table" tool in the Spatial Analyst Extension of ArcGIS 10.5.1 (Appendix B).

Average precipitation. The average monthly precipitation in units of $\mathrm{mm}$ at a spatial resolution of $30 \mathrm{~s}$ or approximately $1 \mathrm{~km} 2$ was used from the world climate dataset. The datasets were then clipped to the study area using the "Extract by Mask" tool and the mean precipitation for January-July was calculated using the "Raster Calculator" tool. The resulting raster was projected and resampled to the selected coordinate system of NAD_1983_California_Teale_Albers_FtUS with 9x9 m cell size (Figure 14). "Zonal Statistics" tool was used to calculate the average precipitation within the $2.41 \mathrm{~km}$ buffer instead of the $30.48 \mathrm{~m}$ buffer. This was because within the $30.48 \mathrm{~m}$ buffer, the precipitation dataset was absent for some of the sites and the buffer was not large enough to include the next closest cell with values. Hence, the $2.41 \mathrm{~km}$ buffer was used for the zonal statistics for this attribute. 


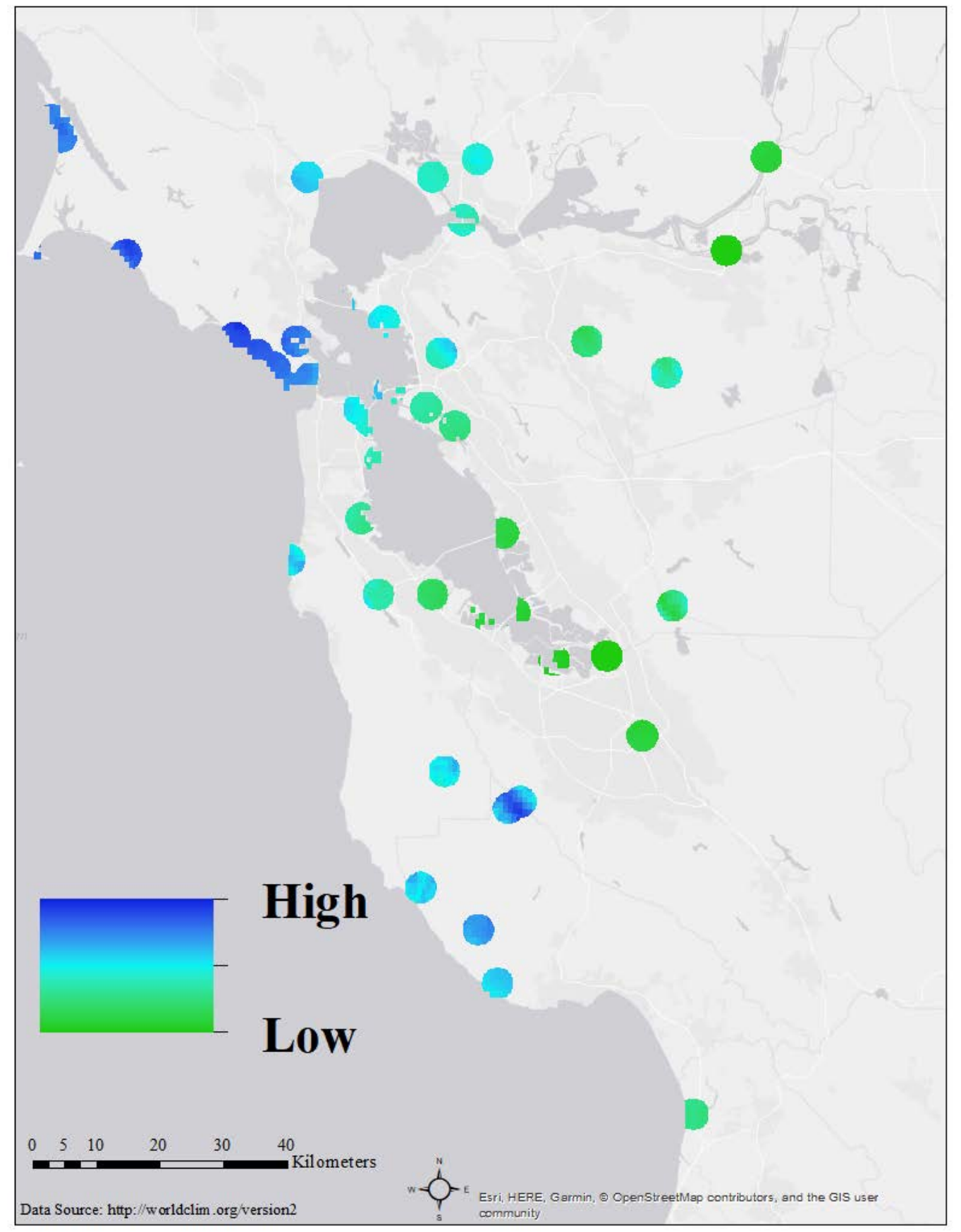

Figure 14. Precipitation within the $2.41 \mathrm{~km}$ buffer at each peregrine falcon nest location (Map was created in ArcMap, ArcGIS Desktop 10.5.1). 
Distance to federally listed species. Similar to the peregrine falcon nest sites, the data obtained for the western snowy plover and California least terns was converted to decimal degrees and using ArcMap, the points were georeferenced to spatial locations and converted to a point feature class. Using the "Near Table" tool, the distance of each peregrine falcon nest site to the centroid of the group of nesting western snowy plovers or the California least tern colony was calculated (Appendix B).

Distance to water. The raw NHD obtained from USGS hydrography dataset provided the digitized hydrology information for all waterways and drainage systems in the study area. Using a combination of query and merge techniques in ArcMap, the dataset was restricted to only waterways including streams, creeks and coastline. This was clipped to the study area and the distance was calculated for each nest location to its nearest water source using the "Near" tool in the Spatial Analyst Extension of ArcGIS (Appendix B). Zonal statistics and the mean distance to water within the $30.48 \mathrm{~m}$ buffer for each site were also calculated.

Temperature. The average monthly temperature in ${ }^{\circ} \mathrm{C}$ at a spatial resolution of $30 \mathrm{~s}$ or approximately $1 \mathrm{~km} 2$ was used from the world climate dataset. The datasets were clipped to the study area using the "Extract by Mask" tool and the mean temperature for January through July was calculated using the "Raster Calculator" tool. The resulting raster was projected and resampled to the selected coordinate system of NAD_1983_California_Teale_Albers_FtUS with 9x9 m cell size (Figure 15). “Zonal Statistics” tool was used to calculate the average temperature within the $2.41 \mathrm{~km}$ buffer instead of the $30.48 \mathrm{~m}$ buffer. This was because within the $30.48 \mathrm{~m}$ buffer, the 
temperature dataset was absent for some of the sites and the buffer was not large enough to include the next closest cell with values. Hence, the $2.41 \mathrm{~km}$ buffer was used for the zonal statistics for this attribute. Temperature values were converted from Celsius to Fahrenheit using the "Raster Calculator" tool with the formula (Temperature $* 1.8)+$ 32. 


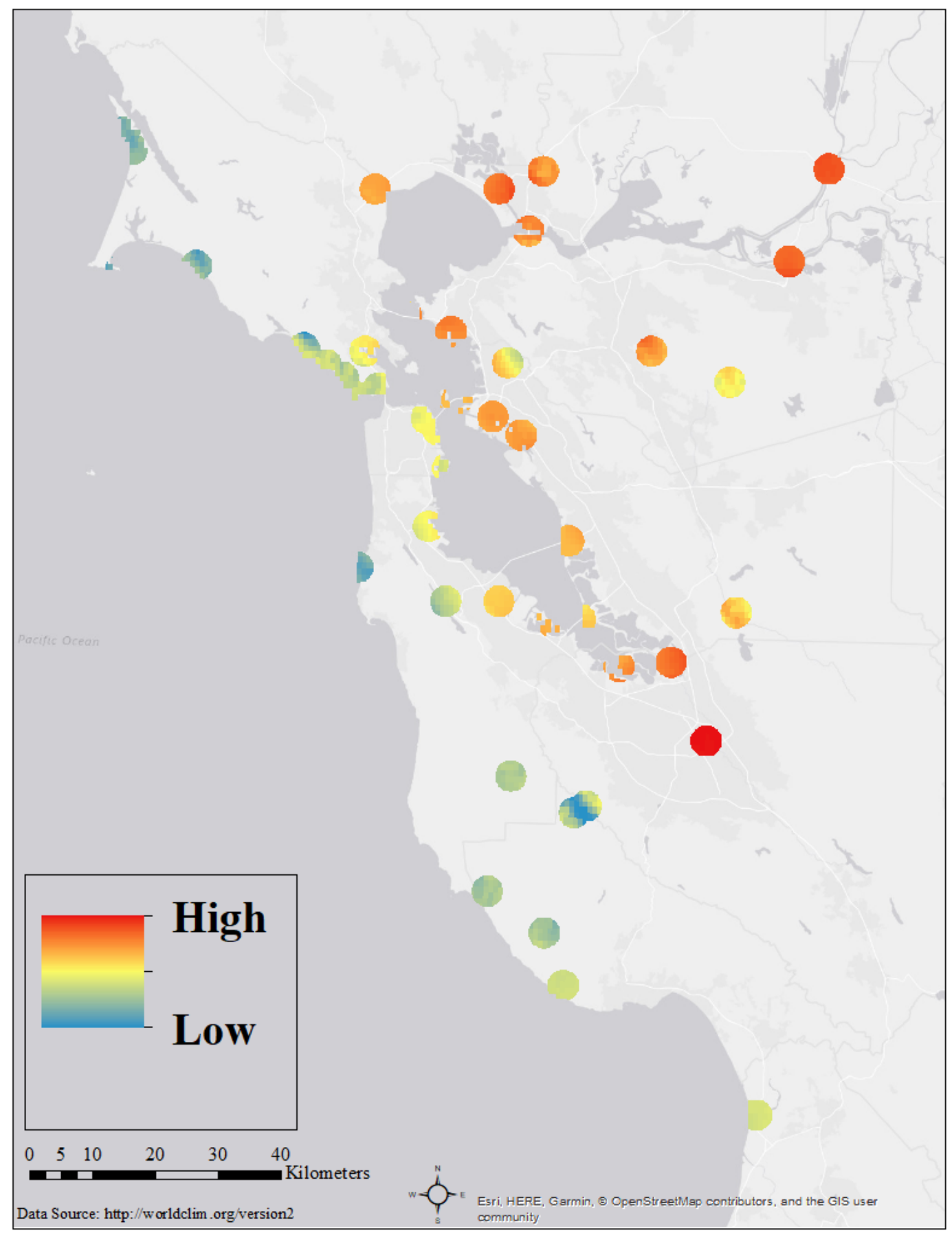

Figure 15. Temperature within the $2.41 \mathrm{~km}$ buffer at each peregrine falcon nest location (Map was created in ArcMap, ArcGIS Desktop 10.5.1). 
Land cover. The remote sensing image for land cover was obtained from the NLCD 2011 dataset from USGS. The original dataset resolution was 30x30 m with map projection Albers Conical Equal Area. The 16 class land cover classification scheme (Appendix B) was consolidated to 4 main categories (Ozialak et al., 2005) (Table 2).

Table 2.

Consolidation of The 16-Class Land Cover Scheme to Four Categories

\begin{tabular}{lrr}
\hline Land cover classification & $\begin{array}{r}\text { Categories } \\
\text { (Ozialak et al., 2005) }\end{array}$ & $\begin{array}{r}\text { 16-class scheme } \\
\text { (Homer et al., 2015) }\end{array}$ \\
\hline Open water/wetlands & 1 & $11,12,90,95$ \\
Urban/Developed-low, med, high & 2 & $21,22,23,24$ \\
Barren rock/scrub/shrub/grasslands & 3 & 31, 51, 52, 71, 72, 73, \\
& & 74,82, \\
Forest/Open space & 4 & $41,42,43$ \\
\hline
\end{tabular}

The dataset was then clipped to the study area using the "Extract by Mask" tool and the resulting raster was then projected and resampled to the selected project coordinate system of NAD_1983_California_Teale_Albers_FtUS with 9x9 m cell size. The land cover class for each site location was extracted using the Spatial Analyst extension tool in ArcGIS, "Extract values to Points” (Figure 16). This was then used as a categorical variable in the overlay PCA analysis. 


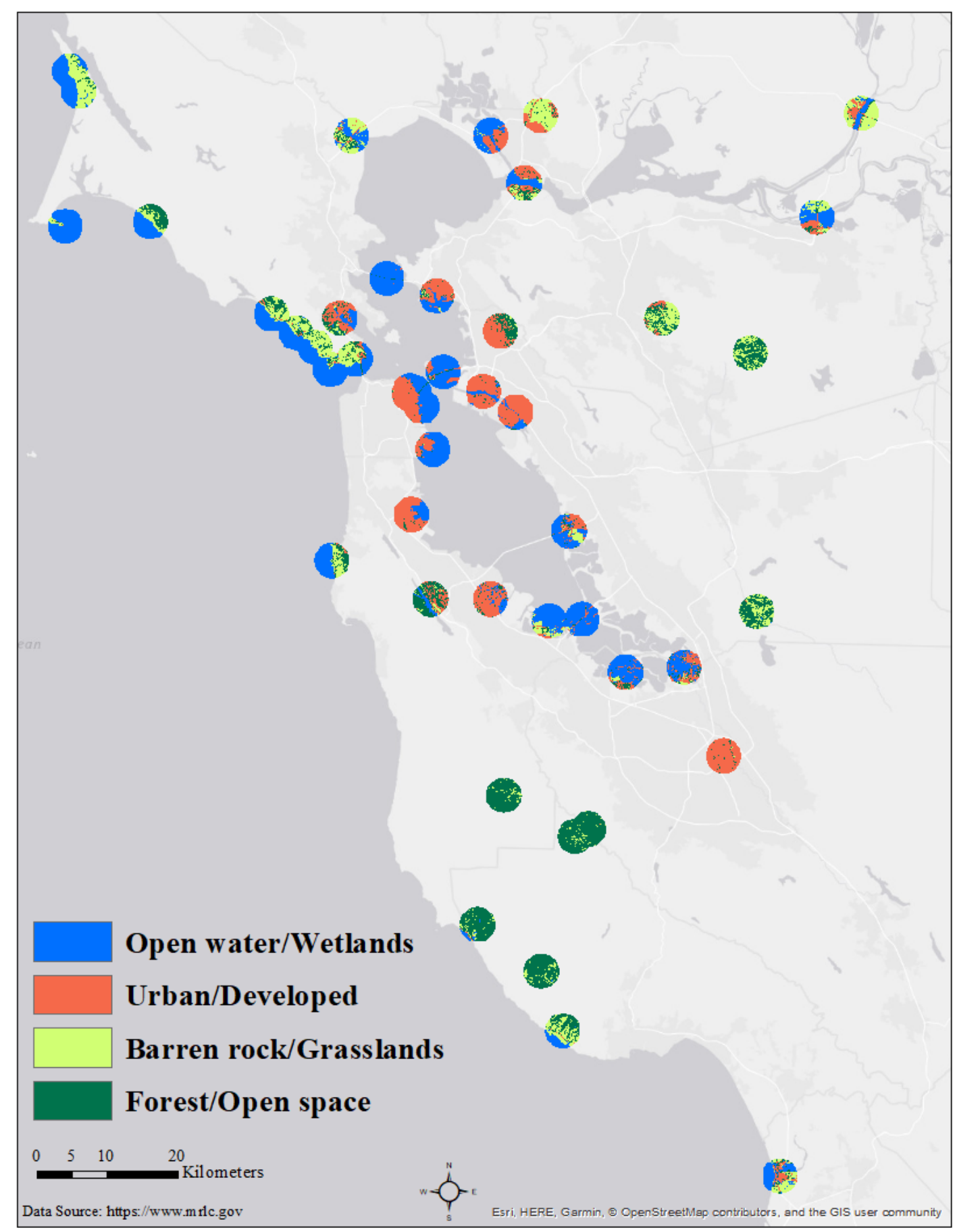

Figure 16. Land cover within the $2.41 \mathrm{~km}$ buffer at each peregrine falcon nest location (Map was created in ArcMap, ArcGIS Desktop 10.5.1). 
Descriptive and inferential statistics. Descriptive statistics for each continuous attribute and the respective histogram with the normal curve (Appendix A) were calculated. To test the null hypotheses, independent samples $t$ test for site categories, anthropogenic and natural, and the Pearson Chi-Square test of independence for the land cover categorical variable were performed. The data sheets used in these tests can be found in the Appendix (C and D).

Principal Component Analysis (PCA). PCA to calculate the loadings and variance for all continuous and standardized attributes was conducted using R statistical software (Appendix D). The temperature attribute was excluded since it highly correlated with solar radiation. Wightman and Fuller (2005) in their study determined that highly correlated variables could result in unusually large coefficients and standard errors; hence elimination of the derivable attribute was adopted. The attribute values for each site were standardized in Microsoft Excel using the formula $\frac{(X-\text { Mean })}{\text { Std.dev }}$. The categorical variable land cover and the site categories of anthropogenic and natural were depicted as an overlay in the graphical output.

\section{Limitations}

This was an exploratory study and hence, a comparative analysis with control sites was not conducted and not all known locations of nest sites for all three species were included in this study. For the nest sites located on hillsides and cliffs, the $30.48 \mathrm{~m}$ or the $2.41 \mathrm{~km}$ buffers may not have been of sufficient size to capture the nest location. The raw data of the San Francisco Bay Area peregrine falcon nest locations received were deliberately off either by a few meters or kilometers to ensure protection to the species. 
In a configuration of nesting sites in close proximity, in order to answer RQ1 (spatial distribution of the nesting sites) in depth and truly understand the spatial distribution pattern of the nesting sites, spatial autocorrelation analysis has to be considered (Koenig, 1999). Spatial autocorrelation is a phenomenon in spatial statistics that assumes objects that are closer to one another are more similar and related than those farther away. The "Spatial Autocorrelation" tool in ArcGIS is often used as a "first-cut" exploration of this phenomenon; the output of the tool helps determine if there is spatially significant clustering, dispersion, or randomness in the input data. The tool, however, requires attribute values to help make this determination. Since in this study, nest locations lacked such attributes (other than latitude/longitude data), (GIS Stack Exchange, 2016), spatial autocorrelation analysis could not be conducted. The next most viable spatial statistics option to evaluate spatial dispersion or clustering of points for this sample population was the determination of the nearest neighbor distance between the nesting sites.

For three sites, 33, 39 and 47, there were no LIDAR data available to calculate the elevation. Hence, elevation raster for these three sites were derived from a $10 \mathrm{~m}$ resolution Digital Elevation Model (DEM) data obtained from USGS (2018), clipped to the $30.48 \mathrm{~m}$ buffer, and projected to match a local coordinate system appropriate for the specific nest locations. The elevation mosaic dataset was then created from the DEM and LAS raster datasets.

The study did not consider occupancy of the nest sites. Only well-known sites were included in the habitat analysis and not necessarily occupied territories. Since a logistic regression based predictive modeling relies on the presence-to-absence ratio of the 
species, and density as well as occupancy were not attributes, a predictive model could not be derived from the results and was beyond the scope of this project. Further, the sample size of 47 sites for the ten attributes examined constituted a small dataset (Gibson et al., 2004).

Climate data obtained from meteorological stations that do not utilize DEM to extract the climate information for points, are insufficient and are generally interjected with errors and ignore microclimate data (Guisan \& Zimmermann, 2000). Climate data for solar radiation from weather stations is not precisely accurate for areas that have a lot of variation in topography since solar radiation values vary dramatically within a small topographic area with a high level of contouring. But, solar radiation derived from DEM datasets is more reliable for highly contoured topography (Tovar-Pescador et al., 2006). In this research, the world climate dataset used for solar radiation attribute was derived from data from numerous weather stations (Fick \& Hijmans, 2017). The results may not have been precisely accurate but still do reflect the values for the area of study and contributed reliably to the prime factors affecting nesting site distribution and in PCA for variance influence determination. The scale of the attributes in this study did not take microclimate into account. This is probably especially critical in built environments where wind patterns and solar radiation can be markedly different on either side of a building (D. A. Bell, personal communication, October 2018). 


\section{Average Nearest Neighbor}

\section{Results}

The mean distance between the 47 nests was $7.69 \mathrm{~km}(\mathrm{SE} \pm 0.71)$ (Table 3). Analysis of the nearest neighbor values showed there was no statistically significant clustering in the distribution of this sample population of 47 sites $(z=-1.556, p=0.120)$. The $z$ score as seen in the idealistic bell curve drawing (Figure 17), falls in the yellow zone indicating the distribution is best described as random rather than clustered or dispersed.

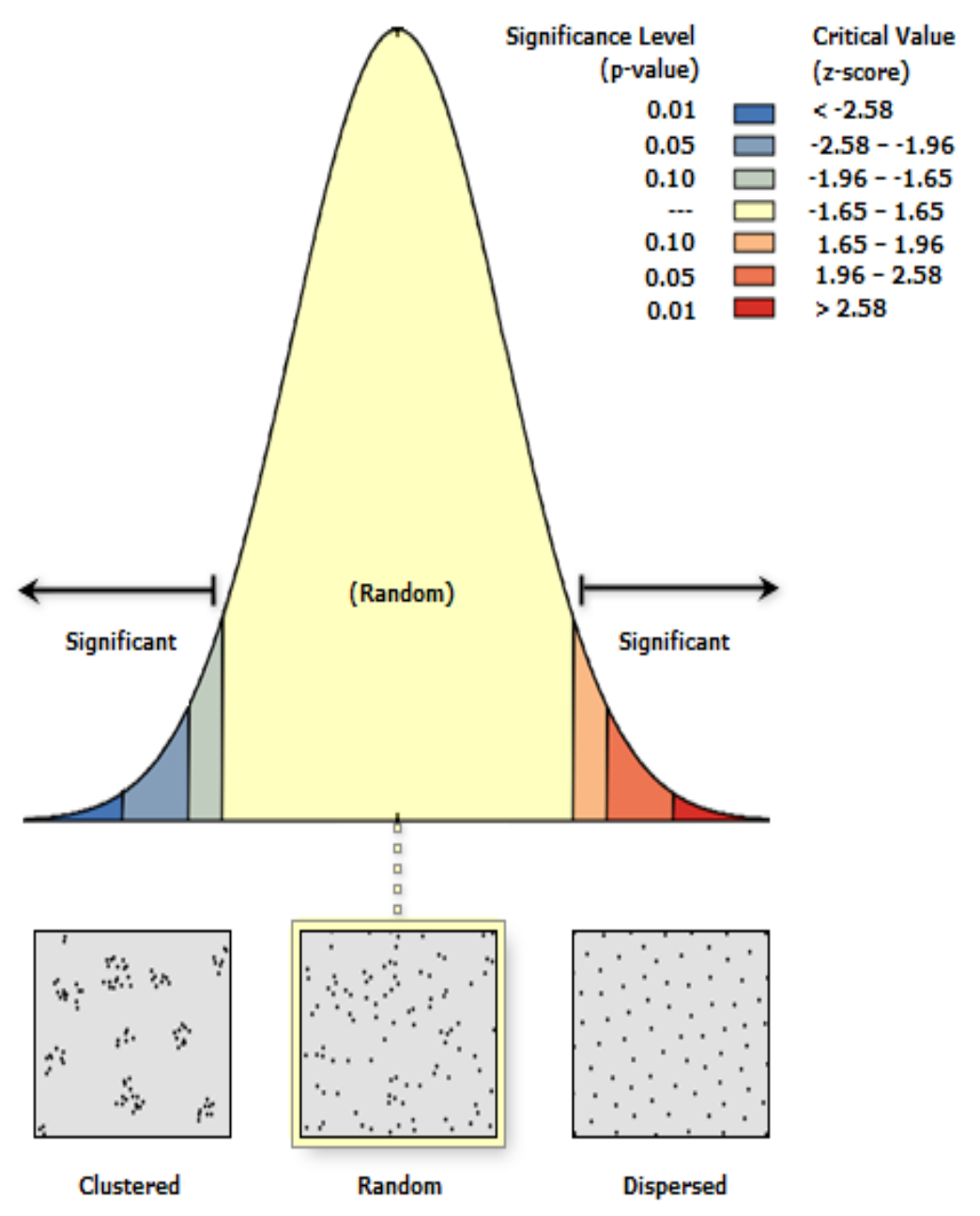

Figure 17. Average nearest neighbor tool statistical output in ArcMap (Spatial Analyst, ArcToolbox, ArcGIS 10.5.1). 


\section{Descriptive Statistics}

The average distance to federally listed prey species (Table 3) was approximately $25.17 \mathrm{~km}$ and most of the sites were located on a water body with an average distance at $0.21 \mathrm{~km}$ (Table 3) from a water source such as coastal/creek/bay. The mean elevation of nest sites was approximately $133.81 \mathrm{~m}$ (Table 3).

Table 3.

Descriptive Statistics Results for Each Attribute

\begin{tabular}{lllll}
\hline Attributes & Minimum & Maximum & Mean & SE \\
\hline Elevation (m) & 7.62 & 919.89 & 133.82 & 27.59 \\
Slope (\%) & 0 & 44 & 14.24 & 2.32 \\
Wind Speed (km/s) & 4.83 & 8.05 & 6.44 & 0.10 \\
Solar Radiation & 17407 & 18591 & 18044.84 & 46.08 \\
$(\mathrm{KJ} / \mathrm{m} \wedge$ 2/day) & & & & \\
NND (km) & 0 & 19.31 & 7.69 & 0.71 \\
Precipitation (mm) & 29 & 99 & 64.67 & 3.06 \\
Distance to federally- & 0 & 72.42 & 25.17 & 2.93 \\
listed species (km) & & & & \\
Distance to water $(\mathrm{km})$ & 0 & 1.61 & 0.21 & 0.08 \\
Temperature (C) & 12.22 & 15.56 & 13.84 & 0.26 \\
\hline
\end{tabular}

\section{Inferential Statistics}

The distances between neighboring peregrine falcon territories did not differ between natural and man-made locations, nor was there a difference in the distance to waterways, and nearly all sites (40 of 47) were located on a waterway. Hence, $\mathrm{H}_{0} 1$ was accepted for these two attributes. However, peregrine falcon nest sites on anthropogenic features were significantly closer to federally listed species than those on natural sites (Table 4).

Therefore, $\mathrm{H}_{0} 1$ was rejected for this attribute. Elevation and percent slope differed between anthropogenic and natural sites, as did precipitation and temperature. Greater precipitation and lower temperatures were recorded on natural sites than at the urban 
man-made structure sites. Hence, $\mathrm{H}_{0} 1$ was rejected for these attributes. But, $\mathrm{H}_{0} 1$ was accepted for wind speed and solar radiation as there was no significant difference for these attributes between natural and anthropogenic sites (Table 4).

Table 4.

Results of The Independent Samples $t$ Test for Each Attribute

\begin{tabular}{|c|c|c|c|c|c|}
\hline Attribute & $\begin{array}{l}\text { Site } \\
\text { Category }\end{array}$ & Mean & $\mathrm{t}$ & $\mathrm{df}$ & Sig. (2-tailed) \\
\hline Elevation (meters) & $\begin{array}{l}\text { Anthro } \\
\text { Natural }\end{array}$ & $\begin{array}{l}59.29 \\
231.33\end{array}$ & -3.127 & 20.078 & 0.005 \\
\hline Slope (\%) & $\begin{array}{l}\text { Anthro } \\
\text { Natural }\end{array}$ & $\begin{array}{l}2.40 \\
28.97\end{array}$ & -10.249 & 27.724 & $<0.001$ \\
\hline Wind $(\mathrm{km} / \mathrm{s})$ & $\begin{array}{l}\text { Anthro } \\
\text { Natural }\end{array}$ & $\begin{array}{l}6.79 \\
6.65\end{array}$ & 0.779 & 28.684 & 0.442 \\
\hline $\begin{array}{l}\text { Solar Radiation } \\
\left(\mathrm{KJ} / \mathrm{m}^{\wedge} 2 / \text { day }\right)\end{array}$ & $\begin{array}{l}\text { Anthro } \\
\text { Natural }\end{array}$ & $\begin{array}{l}18127.76 \\
17938.55\end{array}$ & 2.036 & 29.480 & 0.051 \\
\hline $\mathrm{NND}(\mathrm{km})$ & $\begin{array}{l}\text { Anthro } \\
\text { Natural }\end{array}$ & $\begin{array}{l}8.98 \\
7.71\end{array}$ & 0.717 & 41.705 & 0.478 \\
\hline Precipitation (mm) & $\begin{array}{l}\text { Anthro } \\
\text { Natural }\end{array}$ & $\begin{array}{l}53.55 \\
78.64\end{array}$ & -5.278 & 41.493 & $<0.001$ \\
\hline $\begin{array}{l}\text { Distance to } \\
\text { Federally-Listed } \\
\text { Species }(\mathrm{km})\end{array}$ & Anthro & 16.30 & -3.716 & 41.693 & 0.001 \\
\hline $\begin{array}{l}\text { Distance to Water } \\
(\mathrm{km})\end{array}$ & $\begin{array}{l}\text { Natural } \\
\text { Anthro }\end{array}$ & $\begin{array}{l}35.37 \\
0.39 \\
029\end{array}$ & 0.815 & 43.326 & 0.420 \\
\hline $\begin{array}{l}\text { Temperature } \\
\text { (Celsius) }\end{array}$ & $\begin{array}{l}\text { Anthro } \\
\text { Natural }\end{array}$ & $\begin{array}{r}14.32 \\
13.19 \\
\end{array}$ & 4.923 & 42.521 & $<0.001$ \\
\hline
\end{tabular}

Although the data did not meet the assumptions of this test, land cover attribute showed a statistically significant difference between anthropogenic and natural sites with respect to four categories (open water/wetlands, urban/developed, barren rock/scrub/shrub/grasslands and forests/open spaces). Hence, $\mathrm{H}_{0} 2$ was rejected (Table 5). 
Table 5.

Results of The Pearson Chi-Square Test of Independence for The Land Cover Categorical Attribute

\begin{tabular}{llllllll}
\hline Attribute & $\begin{array}{l}\text { Site } \\
\text { Category }\end{array}$ & $\begin{array}{l}\text { Open } \\
\text { water/ } \\
\text { wetlan } \\
\text { ds }\end{array}$ & $\begin{array}{l}\text { Urban/D } \\
\text { eveloped }\end{array}$ & $\begin{array}{l}\text { Barren } \\
\text { rock/Sh } \\
\text { rub/Gra } \\
\text { sslands }\end{array}$ & $\begin{array}{l}\text { Forest/ } \\
\text { Open } \\
\text { space }\end{array}$ & $\begin{array}{l}\text { df } \\
\text { sig. (2- }\end{array}$ \\
\hline Land cover & Anthro & 10 & 15 & 0 & 1 & 3 & $<0.001$ \\
& Natural & 1 & 0 & 12 & 7 & & \\
\hline
\end{tabular}

\section{Principal Component Analysis}

PCA was run for eight attributes and 45 nesting sites with the exclusion of the categorical variable land cover and the temperature attribute, which was highly correlated with solar radiation. The first three components in the PCA together contributed to over $80 \%$ of the variance. The results in Table 6 show that a significant amount of the variance (61\%) is accounted for by PC1 and PC2 and PC3 accounted for an additional $20 \%$ of the variance. The remaining five components/factors contributed little to the analysis and were not considered (Dallas, 2013). Table 6 shows the percentage variance explained by all the eight components.

Table 6.

Cumulative Variance for Each Component

\begin{tabular}{lll}
\hline Components & $\begin{array}{l}\text { Percentage } \\
\text { Variance }\end{array}$ & $\begin{array}{l}\text { Cumulative } \\
\text { Percentage Variance }\end{array}$ \\
\hline PC1 & 37.565644 & 37.56564 \\
PC2 & 23.826057 & 61.3917 \\
PC3 & 20.186243 & 81.57794 \\
PC4 & 7.321674 & 88.89962 \\
PC5 & 5.4159 & 94.31552 \\
PC6 & 3.45052 & 97.76604 \\
\hline
\end{tabular}




\begin{tabular}{lll}
\hline PC7 & 1.197075 & 98.96311 \\
PC8 & 1.036888 & 100 \\
\hline
\end{tabular}

There is a strong negative correlation between wind speed and solar radiation, wind speed and elevation, and precipitation and solar radiation for the nesting sites in the sample population. Moreover, the attributes NND, solar radiation and distance to the nearest waterway are highly correlated; similarly, precipitation, distance to federally listed species and slope, are highly correlated (Figure 18).

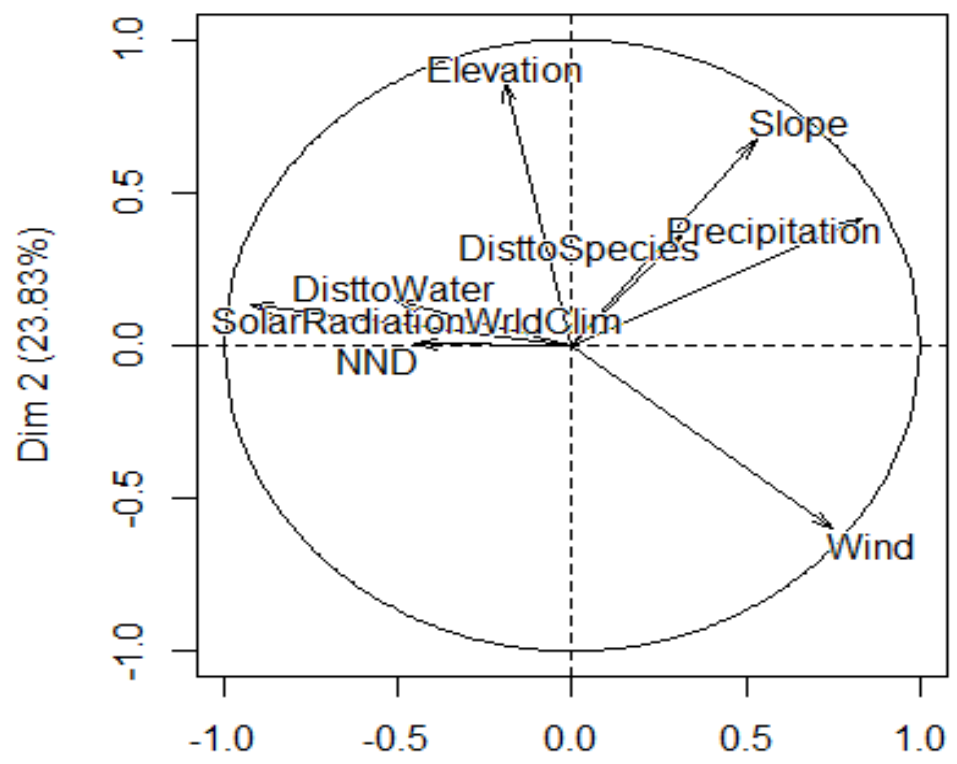

$\operatorname{Dim} 1(37.57 \%)$

Figure 18. Variable loadings of eight peregrine falcon nest site attributes depicted in two dimensions (Dim 1 and 2).

The results in Table 7 show that PC1 is dominated by large-scale environmental factors of solar radiation, precipitation and wind, including a positive relationship with precipitation and wind and a negative relationship with solar radiation. Factors important in PC2 are more local factors, including slope and elevation. PC3 shows a dominance of 
species-related factors such as proximity to other peregrine falcon nests and to the federally listed species.

Table 7.

Variable Loadings for Each Principal Component

\begin{tabular}{lccc}
\hline Variable & PC1 & PC2 & PC3 \\
\hline Slope & 0.5278883 & 0.673197263 & 0.01457885 \\
SolarRadiationWrldClim & -0.9273125 & 0.132354829 & 0.14486961 \\
DisttoSpecies & 0.3174765 & 0.364203886 & 0.75053093 \\
DisttoWater & -0.5083375 & 0.146632384 & -0.57834927 \\
NND & -0.4548848 & 0.003949401 & 0.76328371 \\
Precipitation & 0.8359016 & 0.416534761 & -0.04146984 \\
Wind & 0.7507435 & -0.601034996 & -0.1134567 \\
Elevation & -0.1954767 & 0.863983089 & -0.31419887 \\
\hline
\end{tabular}

Figure 19 depicts a more distributed spread of both natural and anthropogenic sites with regard to the scores in Dim1 while the man-made sites are compressed and not depicting such a distribution along Dim2. And, neither are the bulk of natural sites depicting a distributed spread in Dim 2. There is a clear demarcation along Dim 2 between the anthropogenic and natural sites. Another observation is that the land cover, categorical overlay shows open water/wetlands, a natural land cover category, over the anthropogenic sites. 


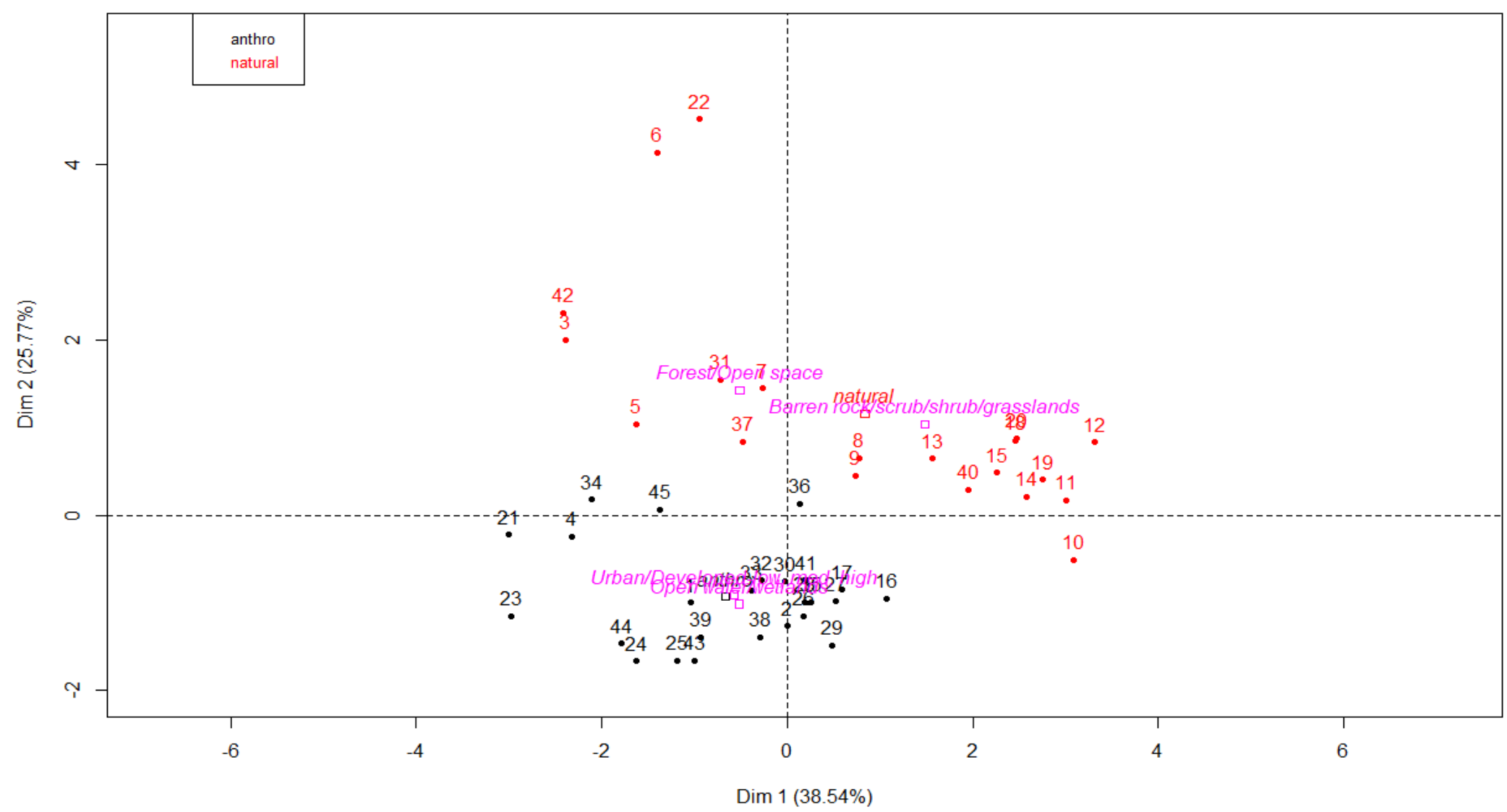

Figure 19. Principal component graph showing peregrine falcon nest sites as scores with land cover overlay. 


\section{Discussion}

This study assessed the features that are associated with peregrine falcon nests in a highly urban setting, the San Francisco Bay Area. The breeding population in this region exhibited no spatial clustering. The result that the distribution was not clustered or dispersed indicates that there is no one factor such as a clustered food source, limited availability of habitat or an indication of competition for resources between conspecifics driving the distribution. Hence, the result implies that resources are probably abundant and there are plentiful available nest sites. Moreover, the distribution of the nest sites in the target study area may be more a function of the fact that potential nesting sites are randomly arrayed around the San Francisco Bay Area and the species is indiscriminate in its selection.

Proximity of peregrine falcon nests to one another averaged $7.69 \mathrm{~km}$ with the least distance between sites being less than $1.61 \mathrm{~km}$. Other studies have found approximately $3.22 \mathrm{~km}$ as the nearest neighbor distance between peregrine falcon nests (Jenkins \& Zyl, 2005; Mathieu et al., 2006). While this study population seems to tolerate conspecifics at close proximity, allowing for an increase in population size, a study of cliff nesting peregrine falcons in natural environments in Greenland found that productivity was greater at cliffs that were farther from each other (Wightman \& Fuller, 2006).

A notable observation about urban nest locations is that while the peregrine falcon generally prefers higher elevation, tall cliffs with ledges, overhangs (Thelander, 1977) and open views of the expanse which in an urban setting includes towers atop structures such as bridges, clock towers, smoke stacks, and buildings, they have also chosen 
suboptimal nest locations such as aircraft hangers, cranes, draw-bridges, ships and underside of bridges (Stewart, 2016). This selectivity of the species with regard to breeding territories possibly limits the nesting population density of peregrine falcons in any given study area (Wightman \& Fuller, 2005) and reduces productivity over time with suboptimal sites being selected by potential breeders (Kauffman et al., 2004).

A study published in 2015 found that over the course of a decade, the average height of peregrine falcon nests in urban areas in the northeastern United States decreased by 39\% (Gahbauer et al., 2015). In the San Francisco Bay Area, some of the bridge location nests are within $12.19 \mathrm{~m}$ or less above the water level and the lack of structure below these nests leads to drowning of the fledglings. Hence, these sites are deemed unsuccessful when it comes to fledging young. Stewart (2016) reported almost all fledges from bridge nest sites were fatal due to drowning. On the contrary, an interesting observation made by Wightman and Fuller (2006) was that at natural cliff habitats in Greenland, peregrine falcons refrained from occupying territories that did not fit certain qualities for like height of the nesting cliffs, protection of the ledges from weather elements, and spacing between neighbors and hence skipped breeding for that season.

Every nest site is within $1.61 \mathrm{~km}$ from its closest water source and more than half the sites in the sample are located on coastal cliffs/bridges and power transmission towers over wetlands. The breeding peregrine falcon population in the San Francisco Bay Area has a high affinity for waterways.

The significant difference in the slope between the natural and anthropogenic sites in this sample is because hillsides and cliffs have a slope associated with the terrain while 
human-made structures do not have a slope with the exception of a crane. Precipitation and temperature between the natural and anthropogenic sites varied quite a bit as well because the natural sites located on coastal cliffs and hillsides with some at steep elevations, are exposed to the extremities in the weather including fog, which also contributes to lower temperatures. Nesting sites on man-made structures in city centers experience higher temperatures due to surface radiation and the heat-island effect (Santamouris, 2001) is a prime factor that alters energy flows due to heat imbalance caused by man-made structures and impervious surfaces. Hence, urban areas have higher temperatures than the surrounding non-urban areas (Seress \& Liker, 2015).

Wind, precipitation, elevation and solar radiation had the most effect on the nesting locations and are prime criteria for nest site selection by peregrine falcon breeding populations. These factors can be potential predictors in a logistic regression model (Gibson et al., 2004) and the predictive modeling could ascertain which attributes define a peregrine falcon nest location and hence forecast future probable nest sites. The land cover varied quite a bit between natural and anthropogenic sites. The open water/wetlands land cover habitat for the anthropogenic sites located on transmission power towers and on bridges, is indicative of the unique estuarine ecosystem of the San Francisco Bay Area. And a nest on a transmission tower located in a marsh or a salt flat is an anthropogenic nest site located in a "natural environment."

While site-specific land cover may not be a good predictor for habitat assessment models (Shabani et al., 2009) highlighting the type of land use between the natural and anthropogenic sites helps to understand suitability for nest locations based on the affinity 
of the species to the site. For example, in this study, several of the peregrine falcons nest sites were located on top of transmission towers and bridges located over open water/wetlands habitat showing an affinity of the species to these specific sites although no other tall structures such as buildings were present.

An important objective of this study was to assess the relationship between falcon nest sites and two federally listed shorebirds. The fact that the results indicate the average distance to the closest sensitive prey species is approximately $25.17 \mathrm{~km}$ perhaps implies that they may not directly impact sensitive species to a great extent when they may be finding larger prey base of pigeons, doves, and passerines at closer distance for lower energy costs. Also, Tokatlian (2017) found that most predation of western snowy plovers in the dried salt ponds in the South San Francisco Bay Area was by the common raven (Corvus corax). Stewart (2016) reported no California least terns were taken by peregrine falcons although several of the known peregrine falcon locations were within foraging distance of the tern colony.

The fact that peregrine falcon nests on anthropogenic features were closer to sensitive prey species than birds on natural features may indicate an attraction to those species. However, this finding may also simply indicate that the topography near the edge of the Bay is essentially flat, and human-made structures are the only source of tall nesting locations. But it cannot be discounted that the mere presence of peregrine falcons in the vicinity of colonies of threatened species can affect its productivity as mentioned earlier (Lourenço et al., 2013; Ydenberg et al., 2004). Hence, if there are potential reasonably tall structures near sensitive species sites, there is a likely chance that peregrine falcons 
would occupy those sites. By not providing conditions that are favorable for peregrine falcon nesting close to a sensitive species would help in the management of both the sensitive and the protected species.

Based on the findings in this study and literature, does it seem that the San Francisco Bay Area could accommodate more peregrine falcon nests? This was an important question in 1975 as well, when recovery efforts were in their early stages and could not be recognized without addressing the carrying capacity in California (Thelander, 1977). According to Mathieu, Seddon, and Leiendecker (2006), eastern New Zealand falcons in a similar study population area of 12,000 $\mathrm{km}^{2}$ had almost reached carrying capacity based on the average NND of approximately $3.22 \mathrm{~km}$ whereas the average NND in this population is approximately $7.69 \mathrm{~km}$. In another study, (Jenkins \& Zyl, 2005) in South Africa it was also found the average distance between nests in a high density peregrine falcon population was approximately $3.22 \mathrm{~km}$. Also the fact that there was no clustering in the distribution also indicates that more peregrines can thrive in this area.

In the San Francisco Bay Area, behavioral observations of one or more nests showed that during breeding seasons, territorial disputes occurred between resident pairs and non-resident individuals. This resulted in the replacement of an adult in the resident pair within a short timeframe as observed with mid-western urban peregrine falcon populations where replacement of individuals in disputes have contributed to mortality rates (Redig \& Tordoff, 1997; Wakamiya \& Roy, 2009). Hence, these immediate replacements of resident mates indicate there could be a floater population (Rutz, 2008) of sub adults with fewer prime territories in the San Francisco Bay Area (Kauffman et al., 
2004). Thelander (1977) observed that while historical, natural, and coastal peregrine falcon breeding sites remained vacant in the immediate post-DDT era, interior sites were experiencing replacements of resident breeding adult peregrine falcons. Wightman and Fuller (2006) found that as the population of peregrine falcons increased in a given area, individual birds sought good quality breeding sites, which meant higher success for reproduction (Zabala \& Zuberogoitia, 2014) and thereby increased the competition.

Based on this study, we can say that peregrine falcons can thrive in many places. Our urban settings are creating an ecological environment that is conducive to peregrine falcons. When there is an ample prey base of shorebirds, rock doves, and passerines in combination with a wide availability of nest site options provided by tall structures such as buildings and bridges peregrine falcons seem to tolerate conspecifics at relatively close quarters. As we divert our Earth’s resources into our cities and inadvertently causing huge populations of pigeons and other birds that do well in human-altered settings, we are creating a prey base that allows for a much higher population of peregrine falcons than were present in this area historically. Cade, Martell, and Redig (1996) determined that in 1993 there were only 19 urban nesting pairs in the entire western United States population of 566 pairs. The population in California alone exceeded 300 active breeding pairs as of 2016 (Stewart, 2016). As we provide the resources peregrine falcons need, they have expanded from historical natural sites, which may now be degraded and/or fragmented, to these urban areas and are trying to co-exist with humans and other urban wildlife. 
As more species move in to smaller habitat footprints, species conflicts are inevitable. Actions such as restoration and trying to incorporate habitats into urban and suburban infrastructure are important to support wildlife populations. When encouraging larger populations of raptors, such as peregrine falcons, considering its impacts on other sensitive species must be part of the evaluation. The results from this study show that, while falcons were attracted to waterways (places that may harbor rare shorebirds), the falcons are also eclectic in the types of features they will nest upon. Attention to creating peregrine falcon habitats away from rare potential prey species can both preserve peregrine falcon populations and other rare species. A multi-species recovery plan that includes a thorough analysis for recovery and tradeoffs for both sensitive predators and prey species (Marshall et al., 2016) would be well served for interactions as explained in this research. 


\section{Recommendations for Management and Future Research}

A future research study on the effects of peregrine falcon predation on shorebirds in the San Francisco Bay Area would be beneficial for conservation management of both predator and sensitive prey species. A similar study was conducted for a mid-Atlantic peregrine falcon population in Virginia (Long \& Roanoke, 2009).

GIS data alone is not comprehensive and accurate enough to make thorough predictions for habitat analysis and species distribution models (Brambilla et al., 2009). Hence, a refinement could look at a combination of both GIS-based and field-based measured attributes (Amici et al., 2015) including the angle/degree of curvature of structures like cranes; aspect/orientation of the nest ledge; overhead cover (Caballero, Bates, Hennen, \& Ashley, 2016; Gahbauer et al., 2015; Wightman \& Fuller, 2005); field evaluation of open views at each nest site (Coulton et al., 2013) which help peregrine falcons defend against predation and provides greater visibility for hunting success of prey (Gahbauer et al., 2015; Mathieu et al., 2006); historical age of nests that may affect suitability and productivity of the nest site (Wightman \& Fuller, 2006).

Some very important environmental predictors that may affect urban peregrine falcon habitat assessments for future research are wind vortex and wind shear around buildings, wind updraft, and solar radiation. Although wind speed is the climatic attribute chosen as the influential variable in most studies (Meineri et al., 2015), wind updraft is possibly the most appropriate variable for the peregrine falcon habitat assessment. In both natural and urban environments, where there are tall cliffs and eyries, the wind updraft at these cliff tops is probably relied upon for defense from predation and to gain stoop advantage for 
hunting (Wightman \& Fuller, 2006). Wind updraft influence (Coulton et al., 2013) is important when the peregrine falcon relies on these updrafts to lift off the ground when it picks up large prey and attempts to fly back to the nest eyrie. A comparative analysis of wind updraft effects between fledging time and in winter when the pair first chooses the site would show the source of selection for choice of a nesting site (W. G. Hunt, personal communication, November 2017). Jenkins (1995) did a comparative study of the flight efficiencies of the southern African peregrine falcon and the sympatric Lanner falcon. He concluded peregrine falcons were less efficient with the use of thermals during foraging and hunting trips although their overall flight speeds were better. They relied on high cliffs to gain wind uplifts and preferred open, unobstructed views of the horizon to help with hunting strategies. This called for more selective tendencies towards territories and habitats that supported its high-speed pursuits. Hence, it would be useful to conduct a similar study in the northern hemisphere, for the San Francisco Bay Area peregrine falcon population to look at wind utilization for flight performance.

Solar radiation or Sun Index is the insolation received by an area and is particularly important for topography where there is high contouring, variability in elevation, slope and aspect of structural elements and hence, casting of shadows. Using DEM datasets to calculate solar radiation will give more accurate measurements since DEM data can be rendered in a manner that takes the orientation and steepness of terrain into account (Tovar-Pescador et al., 2006).

Another area of study to augment the estimation model determined by Kauffman, Pollock, and Walton (2004), is to look at actual measurements on what constitutes this 
steady increase in this subpopulation of the San Francisco Bay Area territories in the present decade. Is it immigration of recruits from surrounding non-urban territories or is it driven by local recruitment (Altwegg et al., 2014) and natal dispersal of first year birds particularly true of the San Francisco Bay Area (Stewart, 2016)? In 2003, the estimated dispersal rates were higher from the sink populations in coastal areas of southern-mid California to the source populations in the urban habitats and an unusual estimated high rate of thriving first year peregrine falcons (Kauffman et al., 2004).

Predictive modeling based on habitat suitability serves as a valuable tool for accurate habitat assessment and conservation management for a species (Mateo-Tomás \& Olea, 2010). In habitats that are very similar, with territories of the species at close proximity, and/or occupied through short natal dispersals of young, it is important to include spatial autocorrelation in the distribution modeling process ((Dennhardt \& Wakamiya, 2013; Stewart, 2016). Hence, a subsequent study to conduct a habitat suitability and predictive modeling of peregrine falcon habitat in the San Francisco Bay Area (Bustamante \& Seoane, 2004; Guisan \& Zimmermann, 2000) would benefit the subpopulation.

The average productivity of nesting peregrine falcons in the San Francisco Bay Area has been recorded at 3.09 young per nest (G. Stewart, personal communication, September, 2014) compared to an average of 1.0-2.0 per territory annually recorded for its entire range in the Northern Hemisphere at the time of delisting (Cade, Enderson, Kiff, \& White, 1997). Hence, the effect of human interference in terms of provision of nesting substrate, nest boxes, and recovery of grounded fledglings (Savard et al., 2000; Altwegg et al., 2014; Gahbauer et al., 2015; Stewart, 2016 ) on population growth, will be helpful 
for the species management in the San Francisco Bay Area. These provisions were favorable for urban breeding peregrine falcons in other studies (Seress \& Liker, 2015; Sorace \& Gustin, 2009a; Gahbauer et al., 2015; Kettel, Gentle, Quinn, \& Yarnell, 2018).

In light of the provisions to boost peregrine falcon populations, Wootton and Bell (1992) were in favor of enhancements of small-sized fragmented subpopulations to prevent extinctions due to variability of growth in the finite population. Hence, it is valuable to understand what habitat attributes contribute to the success of the current urban San Francisco subpopulation that is showing a growth trend. As Pagel, Bell, and Norton (1996) point out, post de-listed peregrine falcon reproductive success is best understood and determined by looking at life history parameters, population demography, and environmental stochasticity (Schipper, Hendriks, Kauffman, Hendriks, \& Huijbregts, 2013) throughout its distribution.

In the San Francisco Bay Area population, it has been observed several bridge fledgling fatalities are due to drowning (Stewart, 2016) and Jenkins (2000a) found peregrine falcons preferred cliffs with many ledges. Eco-design of bridges and buildings with provision for several suitable ledges can be a possible area for future research. As highly specialized raptors show an affinity to urban areas, how can we improve urban environments to be more suitable (Isaac et al., 2008; Sorace \& Gustin, 2009b) to the peregrine falcon and other species? This would be an attempt at reconciliation with nature (Francis, 2011) for relentless human monopolization, addressing an important broader question in urban ecology. From an urban planning perspective, to support the co-existence of avian predators in the urban environments, Sorace and Gustin (2009a) 
recommend the incorporation of structural elements such as tall buildings, towers, and trees likely to be used by avian predators in land-use maps to better understand species distribution in urban areas. This would greatly benefit conservation planning efforts for urban wildlife. There was a similar recommendation by Hickey (1942) to map all known cliffs regardless of occupancy by peregrine falcons. 


\section{References}

Albertson, J. (2015). Personal Communication.

Altwegg, R., Jenkins, A., \& Abadi, F. (2014). Nestboxes and immigration drive the growth of an urban peregrine falcon Falco peregrinus population. Ibis, 156, 107115. https://doi.org/10.1111/ibi.12125

Amato, M., Ossino, A., Brogna, A., Cipriano, M., D’Angelo, R., Dipasquale, G., ... Leonardi, G. (2014). Influence of Habitat and Nest-Site Quality on the Breeding Performance of Lanner Falcons Falco biarmicus. Acta Ornithologica, 49(1), 1-7.

Amici, V., Eggers, B., Geri, F., \& Battisti, C. (2015). Habitat Suitability and Landscape Structure: A Maximum Entropy Approach in a Mediterranean Area. Landscape Research, 40(2), 208-225. https://doi.org/10.1080/01426397.2013.774329

Bamford, A. J., Monadjem, A., \& Hardy, I. C. W. (2009). Nesting habitat preference of the African White - backed Vulture Gyps africanus and the effects of anthropogenic disturbance. Ibis, (September), 51-62. https://doi.org/10.1111/j.1474919X.2008.00878.x

Bell, D. A. (2018). Personal Communication.

Bijleveld, M. (1974). Birds of prey in Europe. London: Macmillan.

Boettcher, Ruth, Mojica, E. K. (2016). First record of peregrine falcon (Falco peregrinus) ground nesting activity on the U.S. Atlantic coast. The Raptor Research Foundation, 50(3), 313-315.

Bond, R. M. (1946). The Peregrine population of western North America. The Condor, 48(3).

Bonn, A., \& Gaston, K. J. (2005). Capturing biodiversity: Selecting priority areas for conservation using different criteria. Biodiversity and Conservation, 14(5), 10831100. https://doi.org/10.1007/s10531-004-8410-6

Booms, T. L., Huettmann, F., \& Schempf, P. F. (2010). Gyrfalcon nest distribution in Alaska based on a predictive GIS model. Polar Biology, 33(3), 347-358. https://doi.org/10.1007/s00300-009-0711-5

Brambilla, M., Rubolini, D., \& Guidali, F. (2004). Rock climbing and Raven Corvus corax occurrence depress breeding success of cliff-nesting Peregrines Falco peregrinus. Ardeola, 51(2), 425-430. 
Brambilla, M., Casale, F., Bergero, V., Crovetto, G. M., Falco, R., Negri, I., ... Bogliani, G. (2009). GIS-models work well, but are not enough: Habitat preferences of Lanius collurio at multiple levels and conservation implications. Biological Conservation, 142(10), 2033-2042. https://doi.org/10.1016/j.biocon.2009.03.033

Brambilla, M., Bassi, E., Ceci, C., \& Rubolini, D. (2010). Environmental factors affecting patterns of distribution and co-occurrence of two competing raptor species. Ibis, 152(2), 310-322. https://doi.org/10.1111/j.1474-919X.2009.00997.x

Brown, L., \& Amadon, D. (1968). Eagles, hawks and falcons of the world. New York: McGraw-Hill.

Brown, J. W., Van Coeverden De Groot, P. J., Birt, T. P., Seutin, G., Boag, P. T., \& Friesen, V. L. (2007). Appraisal of the consequences of the DDT-induced bottleneck on the level and geographic distribution of neutral genetic variation in Canadian peregrine falcons, Falco peregrinus. Molecular Ecology, 16(2), 327-343. https://doi.org/10.1111/j.1365-294X.2007.03151.x

Buchanan, B. (1996). A comparison of behavior and success rates of merlins and peregrine falcons when hunting dunlins in two coastal habitats. Journal of Raptor Research, 30(2), 93-98.

Bustamante, J., \& Seoane, J. (2004). Predicting the Distribution of Four Species of Raptors (Aves: Accipitridae) in Southern Spain: Statistical Models Work Better Than Exisitng Maps. Journal of Biogeography, 31, 295-306. Retrieved from http://www.science.fau.edu/biology/gawliklab/papers/BustamanteJandJSeoane2004. pdf

Butchko. (1990). Predator control for the protection of endangered species in California. Proceedings - Vertebrate Pest Conference, 14(March), 237-240.

Burnham, W., \& Cade, T. J. (2003). Return of the peregrine: a North American saga of tenacity and teamwork. (T. J. Cade \& W. Burnham, Eds.). Boise, Idaho: The Peregrine Fund.

Caballero, I. C., Bates, J. M., Hennen, M., \& Ashley, M. V. (2016). Sex in the city: Breeding behavior of urban peregrine falcons in the Midwestern US. PLoS ONE, 11(7), 1-16. https://doi.org/10.1371/journal.pone.0159054

Cade, Tom J and Martell, Mark and Redig, P. (1996). Peregrine Falcons in Urban North. Raptors in Human Landscapes: Adaptation to Built and Cultivated Environments, 1. 
Cade, T. J., Enderson, J. H., Kiff, L. F., \& White, C. M. (1997). Are There Enough Good Data to Justify De-Listing the American Peregrine Falcon? Wildlife Society Bulletin, 25(3), 730-738.

Carter, J., Moscato, V., \& Tindale, N. (2009). GIS as a rapid decision-support tool for raptor conservation planning in Urbanising landscapes. Australian Geographer, 40(4), 471-494. https://doi.org/10.1080/00049180903312661

Chace, J. F., \& Walsh, J. J. (2006). Urban effects on native avifauna: A review. Landscape and Urban Planning, 74(1), 46-69. https://doi.org/10.1016/j.landurbplan.2004.08.007

Clark, K. E., Zhao, Y., \& Kane, C. M. (2009). Organochlorine pesticides, PCBs, dioxins, and metals in postterm peregrine falcon (Falco peregrinus) eggs from the MidAtlantic States, 1993-1999. Archives of Environmental Contamination and Toxicology, 57(1), 174-184. https://doi.org/10.1007/s00244-008-9248-9

Cloern, J. E., \& Jassby, A. D. (2012). Drivers of change in estuarine - coastal ecosystems: discoveries from four decades of study in San Francisco Bay. Reviews in Geophysics, 50, 1-33. https://doi.org/10.1029/2012RG000397.1.Introduction

Cohen, A. N. (2010). Appendix 2-1 : Habitat Stressor Narrative Descriptions. San Francisco Bay Subtidal Habitat Goals Report. San Francisco.

Collins, J. P., Kinzing, A., Grimm, N. B., Fagan, W. F., Hope, D., Wu, J., \& Borer, E. T. (2000). A new urban ecology. American Scientist, 88(5), 416-425.

Côté, I. M., \& Sutherland, W. J. (1997). The Effectiveness of Removing Predators on Bird Populations. Conservation Biology, 11(2), 395-405.

Coulton, D., Virgl, J., \& English, C. (2013). Falcon nest occupancy and hatch success near two diamond mines in the southern Arctic, Northwest Territories. Avian Conservation and Ecology, 8(2), 1-15. https://doi.org/10.5751/ace-00621-080214

Cresswell, W. (1996). Surprise as a winter hunting strategy in sparrowhawks Accipiter nisus, peregrines Falco peregrinus and merlins F. columbarius. Ibis, 138, 684--692.

Cresswell, W. (2011). Predation in bird populations. Journal of Ornithology, 152, S251S263. https://doi.org/10.1007/s10336-010-0638-1

Curtis, P. D., Cepek, J. D., Mihalco, R., Seamans, T. W., \& Craven, S. R. (2013). Wildlife in Airport Environments : Chapter 6 Wildlife Translocation as a Management Alternative at Airports. 
Dallas, G. (2013). Principal Component Analysis 4 Dummies: Eigenvectors, Eigenvalues and Dimension Reduction. Retrieved July 15, 2018, from https://georgemdallas.wordpress.com/2013/10/30/principal-component-analysis-4dummies-eigenvectors-eigenvalues-and-dimension-reduction/

Dawson, R. D., Mossop, D. H., \& Boukall, B. (2011). Prey Use and Selection in Relation to Reproduction by Peregrine Falcons Breeding along the Yukon River, Canada. Journal of Raptor Research, 45(1), 27-37. https://doi.org/10.3356/JRR-09-84.1

DeCandido, R., \& Allen, D. (2006). Nocturnal Hunting by Peregrine Falcons at the Empire State Building , New York City. The Wilson Journal of Ornithology, 118(1), 53-58.

Dekker, D. (2009). Hunting tactics of Peregrines and other falcons. https://doi.org/10.3356/0892-1016-44.4.331

Dekker, D., Dekker, I., Christie, D., \& Ydenberg, R. (2011). Do Staging Semipalmated Sandpipers Spend the High-Tide Period in Flight over the Ocean to Avoid Falcon Attacks along Shore? Waterbirds, 34(2), 195-201. https://doi.org/10.1675/063.034.0208

DeMent, S. H., J. Julian Chisolm, J., Barber, J. C., \& Strandberg, J. D. (1986). Lead Exposure in an "Urban” Peregrine Falcon and its Avian Prey. Journal of Wildlife Diseases, 22, 238-244.

Dennhardt, A. J., Duerr, A. E., Brandes, D., \& Katzner, T. E. (2015). Integrating citizenscience data with movement models to estimate the size of a migratory golden eagle population. Biological Conservation, 184, 68-78. https://doi.org/10.1016/j.biocon.2015.01.003

Dennhardt, A. J., \& Wakamiya, S. M. (2013). Effective dispersal of peregrine falcons (Falco peregrinus) in the Midwest, U.S.A. Journal of Raptor Research, 47(3), 262270.

Donázar, J. A., Cortés-Avizanda, A., Fargallo, J. A., Margalida, A., Moleón, M., Morales-Reyes, Z., ... Serrano, D. (2016). Roles of Raptors in a Changing World: From Flagships to Providers of Key Ecosystem Services. Ardeola, 63(1), 181-234. https://doi.org/10.13157/arla.63.1.2016.rp8

Dykstra, C. R., Simon, M. M., Daniel, F. B., \& Hays, J. L. (2012). Habitats of Suburban Barred Owls (Strix varia) and Red- Shouldered Hawks (Buteo lineatus) in Southwestern Ohio. Journal of Raptor Research, 46(2), 190-200. https://doi.org/10.3356/JRR-11-05.1 
Elliott, Meredith L and Hurt, Rachel and Sydeman, W. J. (2007). Breeding biology and status of the California least tern Sterna antillarum browni at Alameda Point, San Francisco Bay, California. Waterbirds, 30, 317--325.

ESRI. (2016). An overview of displaying LAS datasets in ArcGIS-Help | ArcGIS for Desktop. Retrieved July 23, 2018, from http://desktop.arcgis.com/en/arcmap/10.3/manage-data/las-dataset/an-overview-ofdisplaying-las-datasets.htm

Fancher, J., Knapp, P., \& Hays, L. (2007). Western Snowy Plover Nesting at Bolsa Chica, Orange County , California 2006, (February).

Fernandez, J. M., \& Gurrutxaga, M. (2010). Habitat Suitability Models for Assessing Bird Conservation Goals in `Special Protection Areas’. Ardeola, 57(SI), 79-91.

Fick, S.E. and Hijmans, R. J. (2016). WorldClim Version2 | WorldClim - Global Climate Data. Retrieved July 15, 2018, from http://worldclim.org/version2

Fick, S. E., \& Hijmans, R. J. (2017). WorldClim 2: new 1-km spatial resolution climate surfaces for global land areas. International Journal of Climatology, 37(12), 43024315. https://doi.org/10.1002/joc.5086

Fischer, R. A. (2000). Riparian Raptors on USACE Projects : Peregrine Falcon. ResearchGate, (JANUARY 2000).

Francis, R. A. (2011). Wall ecology: A frontier for urban biodiversity and ecological engineering. Progress in Physical Geography, 35(1), 43-63. https://doi.org/10.1177/0309133310385166

Francis, R. A., \& Chadwick, M. A. (2012). What makes a species synurbic? Applied Geography, 32(2), 514-521. https://doi.org/10.1016/j.apgeog.2011.06.013

Gahbauer, M. A., Bird, D. M., Clark, K. E., French, T., Brauning, D. W., \& McMorris, F. A. (2015). Productivity, mortality, and management of urban peregrine falcons in northeastern North America. Journal of Wildlife Management, 79(1), 10-19. https://doi.org/10.1002/jwmg.803

Garrott, R. a, White, P. J., \& White, C. a V. (1993). An Issue for Overabundance : Conservation Biologists? Conservation Biology, 7(4), 946-949. https://doi.org/10.1046/j.1523-1739.1993.740946.x

Gibson, L. A., Wilson, B. A., Cahill, D. M., \& Hill, J. (2004). of rufous bristlebird habitat in Spatial prediction a GIS-based approach a coastal heathland : Journal of Applied Ecology, 41(2), 213-223. https://doi.org/10.1111/j.0021-8901.2004.00896.x 
GIS Stack Exchange. (2016). How to work with Spatial Autocorrelation (Morans I) on equal weighted point. Retrieved July 15, 2018, from https://gis.stackexchange.com/questions/189504/how-to-work-with-spatialautocorrelation-morans-i-on-equal-weighted-point

Goals Project. (1999). Baylands Ecosystem Habitat Goals.

Green, M., Swem, T., Morin, M., Mesta, R., Klee, M., Hollar, K., ... Amaral, M. (2003). Monitoring Results for Breeding American Peregrine Falcons (Falco peregrinus anatum), 2003, 26.

Guisan A., \& Zimmermann, N. (2000). Predictive habitat distribution models in ecology. Ecol. Model, 135, 147--186. Retrieved from http://citeseerx.ist.psu.edu/viewdoc/summary?doi=10.1.1.170.1979

Hager, S. (2009). Human-Related Threats to Urban Raptors. Journal of Raptor Research, 43(3), 210-226.

Hedges, A. (2003). Convert Latitude/Longitude to Decimal. Retrieved July 14, 2018, from https://andrew.hedges.name/experiments/convert_lat_long/

Herbert, R. A., \& Skelton, K. G. (1965). Behavior of Peregrine Falcons in the New York City Region. American Ornithological Society, 82(1), 62-94.

Hickey, J. J. (1942). Eastern Population of the Duck Hawk. The Auk, 59(2), 176-204. https://doi.org/10.1890/11-1817.1

Hinchliffe, S., \& Whatmore, S. (2006). Living cities: Towards a politics of conviviality. Science as Culture, 15(2), 123-138.

Hipfner, J. M., Morrison, K. W., \& Darvill, R. (2011). Peregrine Falcons Enable Two Species of Colonial Seabirds to Breed Successfully by Excluding Other Aerial Predators. Waterbirds, 34(1), 82-88. https://doi.org/10.1675/063.034.0110

Holt, A. R., Davies, Z. G., Tyler, C., \& Staddon, S. (2008). Meta-analysis of the effects of predation on animal prey abundance: Evidence from UK vertebrates. PLoS ONE, 3(6). https://doi.org/10.1371/journal.pone.0002400

Homer, C. G., Dewitz, J. A., Yang, L., Jin, S., Danielson, P., Xian, G., ... Megown, K. (2015). Completion of the 2011 National Land Cover Database for the conterminous United States-Representing a decade of land cover change information. Retrieved July 14, 2018, from 
http://www.asprs.org/a/publications/pers/2015journals/PERS_May_2015/HTML/file s/assets/basic-html/index.html\#345/z\%23noFlash

Hornaday, K., Pisani, I., \& Warne, B. (2007). Recovery Plan for the Pacific Coast Population of the Western Snowy Plover (Charadrius alexandrinus nivosus). Sacramento, California.

Hunt, W. G. (1998). Raptor Floaters at Moffat's Equilibrium. Oikos, 82(1), 191-197. Retrieved from https://www.jstor.org/stable/3546929

Hunt, W. G. (2017). Personal Communication.

Hurley, V. G. (2013). Factors affecting breeding success in the Peregrine Falcon ( Falco peregrinus macropus ) across Victoria 1991 - 2012.

Department of the Interior, Federal Register, $71 \S$ (2006). https://doi.org/10.1089/hum.1996.7.15-1923

Isaac, White, Ierodiaconou, C. (2013). Response of a cryptic apex predator to a complete urban to forest gradient. Wildlife Research, 40, 427-436. Retrieved from http://dx.doi.org/10.1071/WR13087

Isaac, B., Cooke, R., Simmons, D., \& Hogan, F. (2008). Predictive mapping of powerful owl (Ninox strenua) breeding sites using Geographical Information Systems (GIS) in urban Melbourne, Australia. Landscape and Urban Planning, 84(3-4), 212-218. https://doi.org/10.1016/j.landurbplan.2007.08.002

Jenkins, A. R. (1995). Morphometrics and Flight Performance of Southern African Peregrine and Lanner Falcons. Journal of Avian Biology, 26(1), 49-58.

Jenkins, A. R. (2000). Hunting mode and success of African Peregrines Falco peregrinus minor: does nesting habitat quality affect foraging efficiency? Ibis, 142(2), 235-246. https://doi.org/10.1111/j.1474-919X.2000.tb04863.x

Jenkins, A. (2000a). Characteristics of peregrine and lanner falcon nesting habitats in South Africa. Ostrich, 71(3-4), 416-424. https://doi.org/10.1080/00306525.2000.9639844

Jenkins, A. (2000b). Factors affecting breeding success of peregrine and lanner falcons in South Africa. Ostrich, 71(3-4), 385-392. https://doi.org/10.1080/00306525.2000.9639837 
Jenkins, A., \& Zyl, A. van. (2005). Conservation status and community structure of cliffnesting raptors and ravens on the Cape Peninsula, South Africa. The Ostrich, 76(3\&4), 175-184.

Jokimaki, Jukka, Huhta, E. (2000). Artificial Nest Predation and Abundance of Birds along an Urban Gradient Author ( s ): Jukka Jokimäki and Esa Huhta Published by: American Ornithological Society Stable URL : http://www.jstor.org/stable/1370311 References Linked references are available. American Ornithological Society, 102(4), 838-847.

Kassara, C., Dimalexis, A., Fric, J., Karris, G., Barboutis, C., \& Sfenthourakis, S. (2012). Nest-site preferences of Eleonora's Falcon (Falco eleonorae) on uninhabited islets of the Aegean Sea using GIS and species distribution models. Journal of Ornithology, 153(3), 663-675. https://doi.org/10.1007/s10336-011-0784-0

Kaufman, K. (2001). Birds of North America. Houghton Mifflin Harcourt.

Kauffman, M. J., Frick, W. F., \& Linthicum, J. (2003). Estimation of Habitat-Specific Demography and Population Growth for Peregrine Falcons in California Estimation of habitat-specific demography and population growth for peregrine falcons in California. Ecological Applications, 13(6), 1802-1816.

Kauffman, M. J., Pollock, J. F., \& Walton, B. (2004). Spatial structure, dispersal, and management of a recovering raptor population. American Naturalist, 164(5), 582597. https://doi.org/10.1086/424763

Keitt, T. H., Bjornstad, O. N., Dixon, P. M., \& Citron-Pousty, S. (2002). Accounting for spatial pattern when modeling organism-environment interactions. Ecography, 25(5), 616-625. https://doi.org/10.1034/j.1600-0587.2002.250509.x

Kettel, E. F., Gentle, L. K., \& Yarnell, R. W. (2016). Evidence of an Urban Peregrine Falcon (Falco peregrinus) Feeding Young At Night. J. Raptor Res, 50(3), 321-323. https://doi.org/10.3356/JRR-16-13.1

Kettel, E. F., Gentle, L. K., Quinn, J. L., \& Yarnell, R. W. (2018). The breeding performance of raptors in urban landscapes: a review and meta-analysis. Journal of Ornithology, 159(1), 1-18. https://doi.org/10.1007/s10336-017-1497-9

Khlopotova, A. V. (2013). Study on the ecology of the peregrine falcon (Falco peregrinus Tunstall, 1771) in the Chusovaya River Nature Park. Russian Journal of Ecology, 44(4), 358-360. https://doi.org/10.1134/s1067413613030065

Kitowski, I., Grzywaczewski, G., Cwiklak, J., Grzegorzewski, M., \& Krop, S. (2011). Falconer activities as a bird dispersal tool at Deblin Airfield (E Poland). 
Transportation Research Part D: Transport and Environment, 16(1), 82-86. https://doi.org/10.1016/j.trd.2010.07.010

Koenig, W. D. (1999). Spatial autocorrelation of ecological phenomena. Trends in Ecology and Evolution, 14(1), 22-26. https://doi.org/10.1016/S01695347(98)01533-X

L’Hérault, V., Franke, A., Lecomte, N., Alogut, A., \& Bêty, J. (2013). Landscape heterogeneity drives intra-population niche variation and reproduction in an arctic top predator. Ecology and Evolution, 3(9), 2867-2879. https://doi.org/10.1002/ece3.675

Larson, V. L., Rowe, S. P., Breininger, D. R., \& Yosef, R. (1994). A Review of Falconry as a Bird Control for Technique with Recommendations for Use at the Shuttle Landing Facility, John F. Kennedy Space Center, Florida, U.S.A.

Long, E. C., \& Roanoke, V. (2009). Prey utilization and energy demand of a breeding Peregrine Falcon (Falco peregrinus) population. College of William and Mary.

López-López, P., García-Ripollés, C., Soutullo, Á., Cadahía, L., \& Urios, V. (2007). Identifying potentially suitable nesting habitat for golden eagles applied to “important bird areas" design. Animal Conservation, 10(2), 208-218. https://doi.org/10.1111/j.1469-1795.2006.00089.x

López-López, P., Verdejo, J., \& Barba, E. (2009). The role of pigeon consumption in the population dynamics and breeding performance of a peregrine falcon (Falco peregrinus) population: Conservation implications. European Journal of Wildlife Research, 55(2), 125-132. https://doi.org/10.1007/s10344-008-0227-2

Lourenço, P. M., Catry, P., Lecoq, M., Ramírez, I., and Granadeiro, J. P. (2013). Role of disturbance, geology and other environmental factors in determining abundance and diversity in coastal avian communities during winter. Marine Ecology Progress Series, 479, 223--234.

Luniak, M. (2004). Synurbization: Adaptation of animal wildlife to urban development. Proceedings 4th International Urban Wildlife Symposium, 50-55.

Maizlish, N., Woodcock, J., Co, S., Ostro, B., Fanai, A., \& Fairley, D. (2013). Health cobenefits and transportation-related reductions in greenhouse gas emissions in the San Francisco Bay Area. American Journal of Public Health, 103(4), 703-709. https://doi.org/10.2105/AJPH.2012.300939 
Marshall, K. N., Stier, A. C., Samhouri, J. F., Kelly, R. P., \& Ward, E. J. (2016). Conservation Challenges of Predator Recovery. Conservation Letters, 9(1), 70-78. https://doi.org/10.1111/conl.12186

Marzluff, J. M. (2005). Island biogeography for an urbanizing world: how extinction and colonization may determine biological diversity in human-dominated landscapes. Urban Ecosystems, (8), 157-177. https://doi.org/10.1007/978-0-387-73412-5

Mateo-Tomás, P., \& Olea, P. P. (2010). Anticipating knowledge to inform species management: Predicting spatially explicit habitat suitability of a colonial vulture spreading its range. PLoS ONE, 5(8). https://doi.org/10.1371/journal.pone.0012374

Mathieu, R., Seddon, P., \& Leiendecker, J. (2006). Predicting the distribution of raptors using remote sensing techniques and geographic information systems: A case study with the Eastern New Zealand falcon (Falco novaeseelandiae). New Zealand Journal of Zoology, 33(1), 73-84. https://doi.org/10.1080/03014223.2006.9518432

Meineri, E., Deville, A. S., Grémillet, D., Gauthier-Clerc, M., \& Béchet, A. (2015). Combining correlative and mechanistic habitat suitability models to improve ecological compensation. Biological Reviews, 90(1), 314-329. https://doi.org/10.1111/brv.12111

Morishita, T. Y., Fullerton, A. T., Lowenstine, L. J., Gardner, I. A., \& Brooks, D. L. (1998). Morbidity and Mortality in Free-Living Raptorial Birds of Northern California: A Retrospective Study 1983-1984. Journal of Avian Medicine and Surgery, 12(2), 78-81.

Newton, I., Gammie, I., \& Gammie, Jim. (1979). Population ecology of raptors(Poyser Monographs). Berkhamsted, England: T. \& A.D. Poyser.

Newton, I., \& Olsen, P. (1990). Birds of prey. Merehurst.

Noguera, J. C., Pérez, I., \& Mínguez, E. (2010). Impact of terrestrial wind farms on diurnal raptors: Developing a spatial vulnerability index and potential vulnerability maps. Ardeola, 57(1), 41-53.

Okamoto, Rubissow, A., \& Wong, K. M. (2011). Natural History of San Francisco Bay. Berkeley: Univ of California Press.

Oro, D. (1996). Colonial Seabird Nesting in Dense and Small Sub-Colonies : An Advantage against Aerial Predation. The Condor, 98(4), 848-850. 
Ozialak, M. R., Lacki, M. J., \& Carter, K. M. (2005). Characterization of Potential Release Sites for Peregrine Falcon Reintroduction. Natural Areas Journal, 25(2), 188-196. https://doi.org/10.1016/j.ijrobp.2010.07.1515

Pagel, J. E., Bell, D. A., \& Norton, B. E. (1996). De-Listing the American Peregrine Falcon: Is it Premature? Wildlife Society Bulletin, 24(3), 429-435.

Pagel, J. E., Patton, R. T., \& Latta, B. (2010). Ground Nesting of Peregrine Falcons (Falco peregrinus) Near San Diego, California. Journal of Raptor Research, 44, 323--325.

Paine, R. T., Wootton, J. T., \& Boersma, P. D. (1990). Direct and Indirect Effects of Peregrine Falcon Predation on Seabird Abundance. The Auk, 107(1), 1-9.

Palomino, D., \& Carrascal, L. M. (2007). Habitat associations of a raptor community in a mosaic landscape of Central Spain under urban development. Landscape and Urban Planning, 83(4), 268-274. https://doi.org/10.1016/j.landurbplan.2007.04.011

Patton, C. (2002). Turning Salt into Environmental Gold: Wetland Restoration in the South San Francisco Bay Salt Ponds. Save San Francisco Bay Association.

Pearl, B. G. (2015). Factors affecting winter foraging habitat selection of Western Snowy Plovers in South San Francisco Bay Ponds. San Jose State University.

Pearl, B. G. (2015). Personal Communication.

Pearl, B., Tokatlian, K., Scullen, J., Strong, C., \& Krause, J. (2017). Western Snowy Plover Monitoring in the San Francisco Bay Annual Report.

Pries, A. (2015). San Francisco - Oakland Bay Bridge East Span Seismic Safety Project.

Pulliam, H. R. (1988). Sources, sinks, and population regulation. The American Naturalist, 132(5), 652-661.

Quinn, J. L. (1997). The effects of hunting peregrines Falco peregrinus on the foraging behaviour and efficiency of the oystercatcher Haematopus ostralegus. Ibis, 139, 170-173 .

Ratcliffe, D. (2010). The Peregrine Falcon. London: T \& AD Poyser Ltd.

Redig, P. T., \& Tordoff, H. B. (1997). Midwest Peregrine Falcon Demography, 19821995. The Raptor Research Foundation, 31(4), 339-346. 
Rejt, L. (2001). Feeding activity and seasonal changes in prey composition of urban peregrine falcons Falco peregrinus. Acta Ornithologica, 36(2), 165-169. https://doi.org/10.3161/068.036.0201

Rissman, Adena R and Merenlender, A. M. (2008). The conservation contributions of conservation easements: analysis of the San Francisco Bay Area protected lands spatial database. Ecology and Society, 13.

Ritchie, R. J., \& Shook, J. E. (2011). Recovery and trends of peregrine falcons breeding in the Yukon-Tanana uplands, East-Central Alaska, 1995-2003. Journal of Raptor Research, 45(2), 150-159.

Robinson-nilsen, C., Demers, J. B., \& Strong, C. (2010). Western Snowy Plover Numbers, Nesting Success, Fledging Success and Avian Predator Surveys in the San Francisco Bay, 2010., (December), 36.

Robinson-Nilsen, C and Demers, J and Strong, C. (2011). Western Snowy Plover numbers, nesting success, fledging success and avian predator surveys in the San Francisco Bay, 2011. Unpublished Report. San Francisco Bay Bird Observatory, Milpitas, CA.

Roth, T. C., Vetter, W. E., \& Lima, S. L. (2008). Spatial ecology of winting accipiter hawks: home range, habitat use, and the influence of bird feeders. The Condor, 110(2), 260-268. https://doi.org/10.1525/cond.2008.8489

Rullman, Stan and Marzluff, J. M. (2014). Raptor Presence Along an Urban-Wildland Gradient: Influences of Prey Abundance and Land Cover. Journal of Raptor Research, 48(3), 257-272.

Rutz, C. (2008). The establishment of an urban bird population. Journal of Animal Ecology, 77, 1008-1019. https://doi.org/10.1111/j.1365-2656.2007.0

Santamouris, M. (2001). Heat-island effect (Vol. 402). James \& James: London.

SARA, (2016). Species at Risk Public Registry - COSEWIC assessment and update status report on the Peregrine Falcon (pealei subspecies and anatum/tundrius subspecies) in Canada. Retrieved July 23, 2018 from https://www.registrelepsararegistry.gc.ca/default.asp?lang=En\&n=6886BC7C-1\&offset=4\&toc=hide

Savard, J. P. L., Clergeau, P., \& Mennechez, G. (2000). Biodiversity concepts and urban ecosystems. Landscape and Urban Planning, 48(3-4), 131-142.

https://doi.org/10.1016/S0169-2046(00)00037-2 
Schipper, A. M., Hendriks, H. W. M., Kauffman, M. J., Hendriks, A. J., \& Huijbregts, M. A. J. (2013). Modelling interactions of toxicants and density dependence in wildlife populations. Journal of Applied Ecology, 50(6), 1469-1478.

https://doi.org/10.1111/1365-2664.12142

Scott, J. M., Goble, D. D., Haines, A. M., Wiens, J. A., \& Neel, M. C. (2010). Conservation-reliant species and the future of conservation. Conservation Letters, 3(2), 91-97. https://doi.org/10.1111/j.1755-263X.2010.00096.x

Seress, G., \& Liker, A. (2015). Habitat urbanization and its effects on birds. Acta Zoologica Academiae Scientiarum Hungaricae, 61(4), 373-408. https://doi.org/10.17109/AZH.61.4.373.2015

Sergio, F., Rizzolli, F., Marchesi, L., \& Pedrini, P. (2004). The Importance of Interspecific Interactions for Breeding-Site Selection : Peregrine Falcons Seek Proximity to Raven Nests. ECOGRAPHY, 27(6), 818-826.

Shabani, A. A., McArthur, L. C., \& Abdollahian, M. (2009). Comparing different environmental variables in predictive models of bird distribution. Russian Journal of Ecology, 40(7), 537-542. https://doi.org/10.1134/S1067413609070133

Smith, R. K., Pullin, A. S., Stewart, G. B., \& Sutherland, W. J. (2010). Effectiveness of Predator Removal for Enhancing Bird Populations. Conservation Biology (Vol. 24). https://doi.org/10.1111/j.1523-1739.2009.01421.x

Smits, J. E. G., \& Fernie, K. J. (2013). Avian wildlife as sentinels of ecosystem health. Comparative Immunology, Microbiology and Infectious Diseases, 36(3), 333-342. https://doi.org/10.1016/j.cimid.2012.11.007

Soldatini, C., Albores-Barajas, Y. V., Torricelli, P., \& Mainardi, D. (2008). Testing the efficacy of deterring systems in two gull species. Applied Animal Behaviour Science, 110(3-4), 330-340. https://doi.org/10.1016/j.applanim.2007.05.005

Sorace, A. (2002). High density of bird and pest species in urban habitats and the role of predator abundance. Ornis Fennica, 79, 60-71.

Sorace, A., \& Gustin, M. (2009a). Bird species of conservation concern along urban gradients in Italy. Biodiversity and Conservation, 19(1), 205-221. https://doi.org/10.1007/s10531-009-9716-1

Sorace, A., \& Gustin, M. (2009b). Distribution of generalist and specialist predators along urban gradients. Landscape and Urban Planning, 90(3-4), 111-118. https://doi.org/10.1016/j.landurbplan.2008.10.019 
Stachura-Skierczyńska, K., \& Kosiński, Z. (2014). Evaluating Habitat Suitability for the Middle Spotted Woodpecker Using a Predictive Modelling Approach. Annales Zoologici Fennici, 51(4), 349-370. https://doi.org/10.5735/086.051.0402

Stevens, L. E., Brown, B. T., \& Rowell, K. (2009). Foraging Ecology of Peregrine Falcons (Falco peregrinus) along the Colorado River, Grand Canyon, Arizona. The Southwestern Naturalist, 54(3), 284-299.

Stewart, G. R. (2008). (2014). (2015). Personal Communication.

Stewart, G. R. (2016). A Report on 2015 activities authorized under: scientific collecting permit SC-010757. Santa Cruz, California.

Stout, W. E., \& Rosenfield, R. N. (2010). Colonization, Growth, and Density of a Pioneer Cooper's Hawk Population in a Large Metropolitan Environment. Journal of Raptor Research, 44(4), 255-267. https://doi.org/10.3356/JRR-09-26.1

Stralberg, D., Fehring, K. E., Pomara, L. Y., Nur, N., Adams, D. B., Hatch, D., ... Allen, S. (2009). Modeling nest-site occurrence for the Northern Spotted Owl at its southern range limit in central California. Landscape and Urban Planning, 90(1-2), 76-85. https://doi.org/10.1016/j.landurbplan.2008.10.014

Takekawa, J. Y., Lu, C. T., \& Pratt, R. T. (2001). Avian communities in baylands and artificial salt evaporation ponds of the San Francisco Bay estuary. Hydrobiologia, 466, 317-328. https://doi.org/10.1023/A:1014546524957

Takekawa, J. Y., Woo, I., Gardiner, R., Casazza, M., Ackerman, J. T., Nur, N., ... Spautz, H. (2011). Avian Communities in Tidal Salt Marshes of San Francisco Bay: A Review of Functional Groups by Foraging Guild and Habitat Association. San Francisco Estuary and Watershed Science, 9(3), 1-24. https://doi.org/10.5811/westjem.2011.5.6700

Tangley, L. (1986). The Urban Ecologist. BioScience, 36(2), 68-71. Retrieved from http://www.jstor.org/stable/1310103

Thatcher, B., \& Smith, A. H. (2012). Peregrine falcon (Falco peregrinus). SC SWAP 2015, (2005). https://doi.org/10.2173/bna.660

TheCornellLab. (2010). Peregrine Falcon Identification, All About Birds, Cornell Lab of Ornithology. Retrieved August 10, 2018, from https://www.allaboutbirds.org/guide/Peregrine_Falcon/id

Thelander, C. G. (1977). The breeding status of peregrine falcons in California. San Jose State University. 
Thorne, J. H., Santos, M. J., \& Bjorkman, J. H. (2013). Regional Assessment of Urban Impacts on Landcover and Open Space Finds a Smart Urban Growth Policy Performs Little Better than Business as Usual. PLoS ONE, 8(6), 2-10. https://doi.org/10.1371/journal.pone.0065258

Tokatlian, K. (2017). Evaluation of oyster shell enhancement on western snowy plover breeding success, 73 .

Tokatlian, K., Scullen, J., \& Burns, C. (2014). Western Snowy Plover Monitoring in the San Francisco Bay Annual Report 2012.

Tordoff, H. B., \& Redig, P. T. (2001). Role of genetic background in the success of reintroduced reregrine falcons. Conservation Biology, 15(2), 528-532.

Tornberg, R., Korpimäki, V. M., Rauhala, P., \& Rytkönen, S. (2016). Peregrine Falcon (Falco peregrinus) may affect local demographic trends of wetland bird prey species. Ornis Fennica, 93(3), 172-185.

Tovar-Pescador, J., Pozo-Vázquez, D., Ruiz-Arias, J. A., Batlles, J., López, G., \& Bosch, J. L. (2006). On the use of the digital elevation model to estimate the solar radiation in areas of complex topography. Meteorological Applications, 13(3), 279-287. https://doi.org/10.1017/S1350482706002258

Trulio, L. (2015). Personal Communication.

U.S. Department of the Interior | U.S. Geological Survey. (2018). The National Map. Retrieved July 15, 2018, from https://nationalmap.gov/

Wakamiya, S. M., \& Roy, C. L. (2009). Use of monitoring data and population viability analysis to inform reintroduction decisions: Peregrine falcons in the Midwestern United States. Biological Conservation, 142(8), 1767-1776. https://doi.org/10.1016/j.biocon.2009.03.015

Watson, E. B., \& Byrne, R. (2009). Abundance and diversity of tidal marsh plants along the salinity gradient of the San Francisco Estuary: Implications for global change ecology. Plant Ecology, 205(1), 113-128. https://doi.org/10.1007/s11258-009-96027

Weidensaul, S. (2004). The raptor almanac: A comprehensive guide to eagles, hawks, falcons, and vultures. Guilford, Conn.: Lyons Press.

Whelan, C. J., Wenny, D. G., \& Marquis, R. J. (2008). Ecosystem services provided by birds. Annals of the New York Academy of Sciences, 1134, 25-60.

https://doi.org/10.1196/annals.1439.003 
White, C. M., Clum, N. J., Cade, T. J., \& Grainger, H. W. (2002). Peregrine Falcon (Falco peregrinus). The Birds of North America Online.

https://doi.org/10.2173/bna.660

White, C. M., Cade, T. J., \& Enderson, J. H. (2013). Peregrine Falcons of the World. Barcelona, Spain: Lynx Edicions.

White, J. H., Smith, J. M., Bassett, S. D., Brown, J. L., \& Ormsby, Z. E. (2018). Raptor nesting locations along an urban density gradient in the Great Basin, USA. Urban Ecosystems, 21(1), 51-60. https://doi.org/10.1007/s11252-017-0705-y

Whitfield, P. D. (1985). Raptor predation on wintering waders in southeast Scotland. Ibis, 127, 544--558.

Whitfield, D. P. (2003). Raptor predation on non-breeding shorebirds: some thoughts for the future . Wader Study Group Bulletin, 100(April), 134-137.

Wightman, C. S., \& Fuller, M. R. (2005). Spacing and Physical Habitat Selection Patterns of Peregrine Falcons in Central West Greenland. Wilson Ornithological Society, 117(3), 226-236.

Wightman, C. S., \& Fuller, M. R. (2006). Influence of Habitat Heterogeneity on Distribution , Occupancy Patterns , and Productivity of Breeding Peregrine Falcons in Central West Greenland. The Condor, 108(2), 270-281.

Wootton, T. J., \& Bell, D. A. (1992). A Metapopulation Model of the Peregrine Falcon in California: Viability and Management Strategies. The Ecological Society of America, 2, 307-321.

Wootton, J. T., \& Bell, D. A. (2014). Assessing predictions of population viability analysis: Peregrine Falcon populations in California. Ecological Applications, 24(6), 1251-1257. https://doi.org/10.1890/13-1323.1

Ydenberg, R. C., Butler, R. W., Lank, D. B., Smith, B. D., \& Ireland, J. (2004). Western sandpipers have altered migration tactics as peregrine falcon populations have recovered. Proceedings of the Royal Society B: Biological Sciences, 271(1545), 1263-1269. https://doi.org/10.1098/rspb.2004.2713

Ydenberg, R., \& Dekker, D. (2004). Raptor predation on wintering dunlins in relation to the tidal cycle. The Condor, 106(October 2003), 415-419. https://doi.org/10.1242/jeb.089763 
Zabala, J., \& Zuberogoitia, I. (2014). Individual quality explains variation in reproductive success better than territory quality in a long-lived territorial raptor. PLOS ONE, 9(3). https://doi.org/10.1371/journal.pone.0090254

Zarn, M. (1974). Habitat management series for unique or endangered species; Report number 12: Osprey, Pandion haliaetus carolinensis. 


\section{Appendices}

Appendix A: Descriptive Statistics - Histograms

(1)

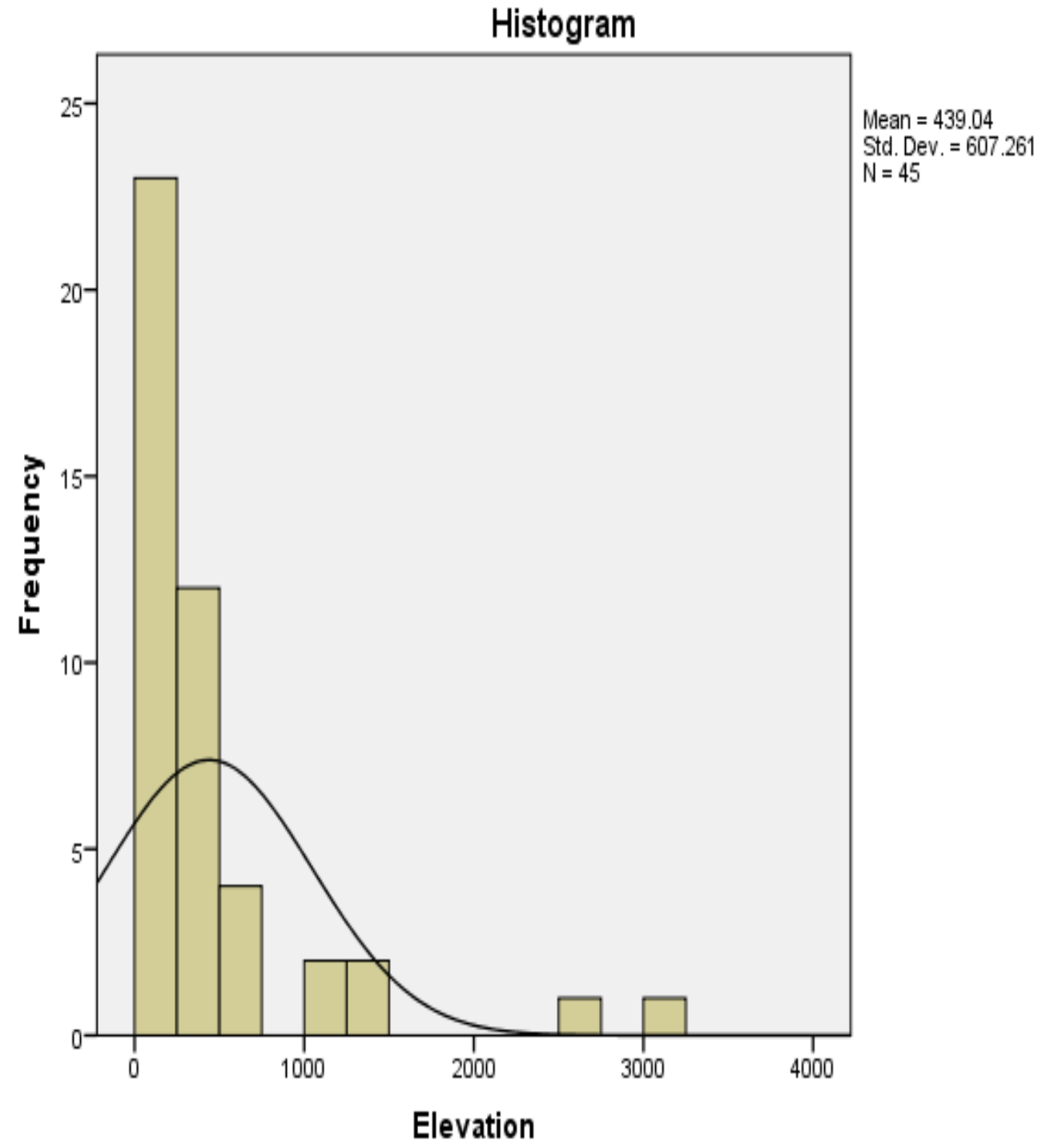

Figure 20. Descriptive statistics for elevation. 
(2)

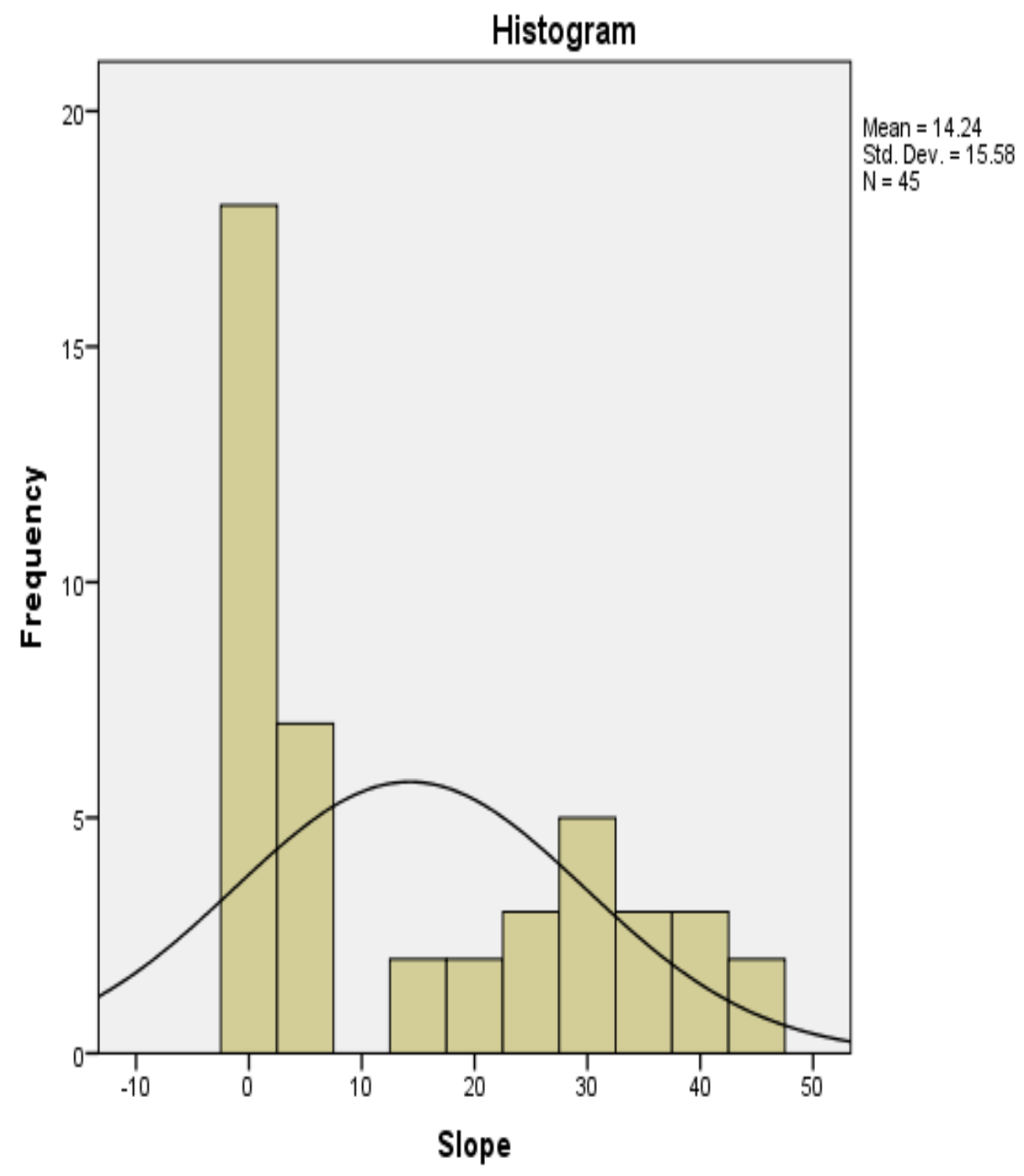

Figure 21. Descriptive statistics for slope. 
(3)

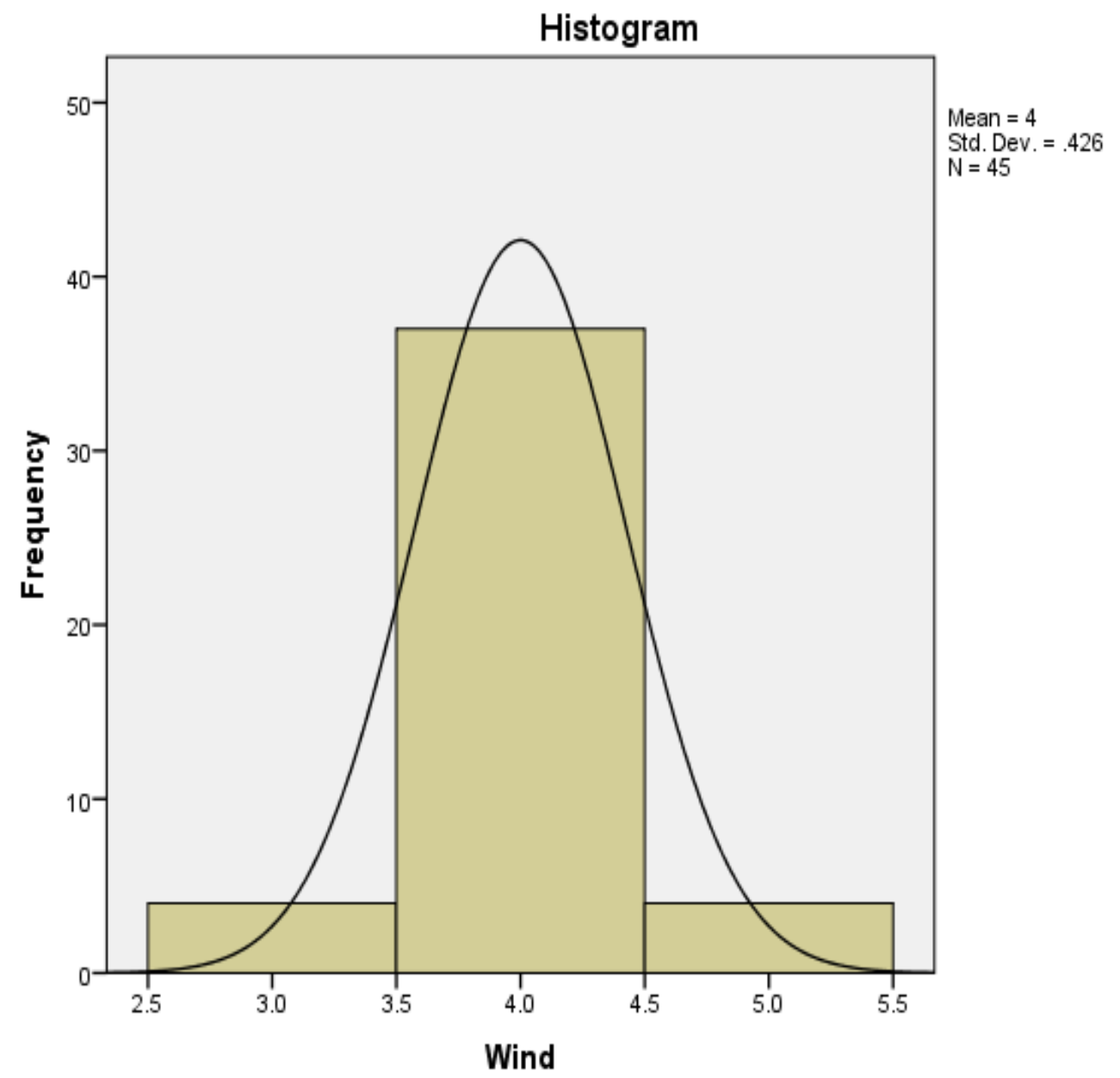

Figure 22. Descriptive statistics for wind speed. 
(4)

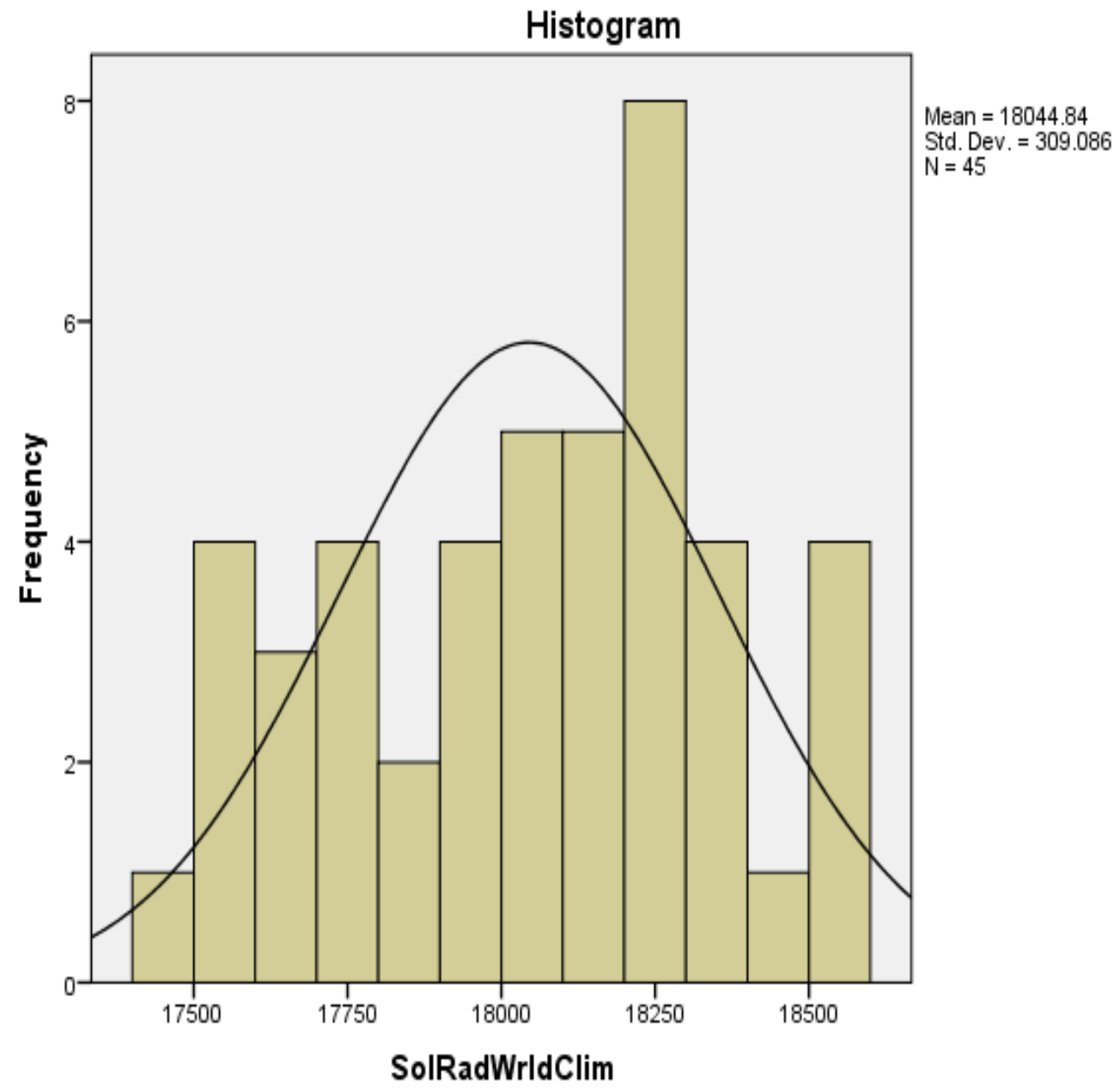

Figure 23. Descriptive statistics for solar radiation. 
(5)

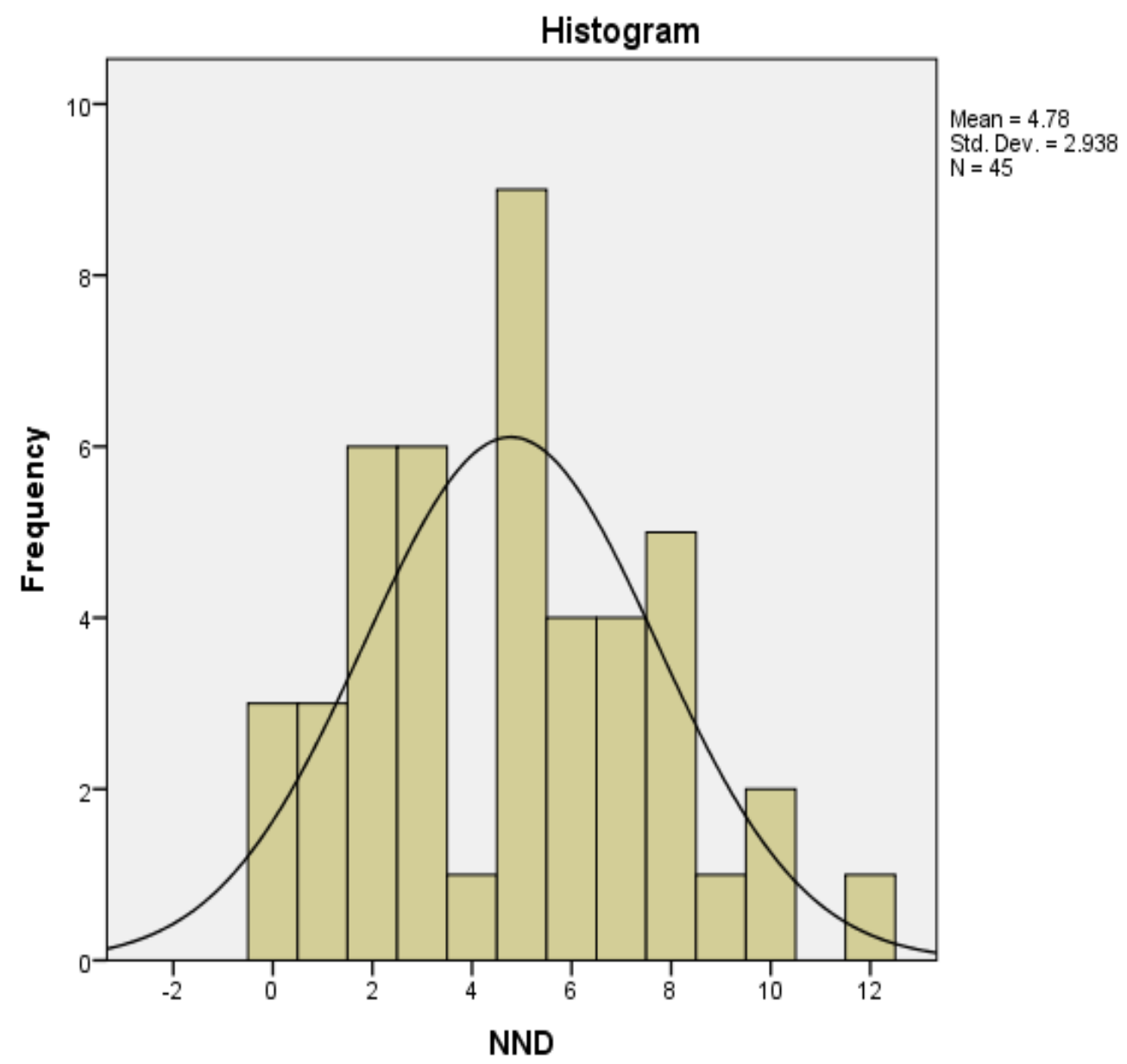

Figure 24. Descriptive statistics for NND. 
(6).

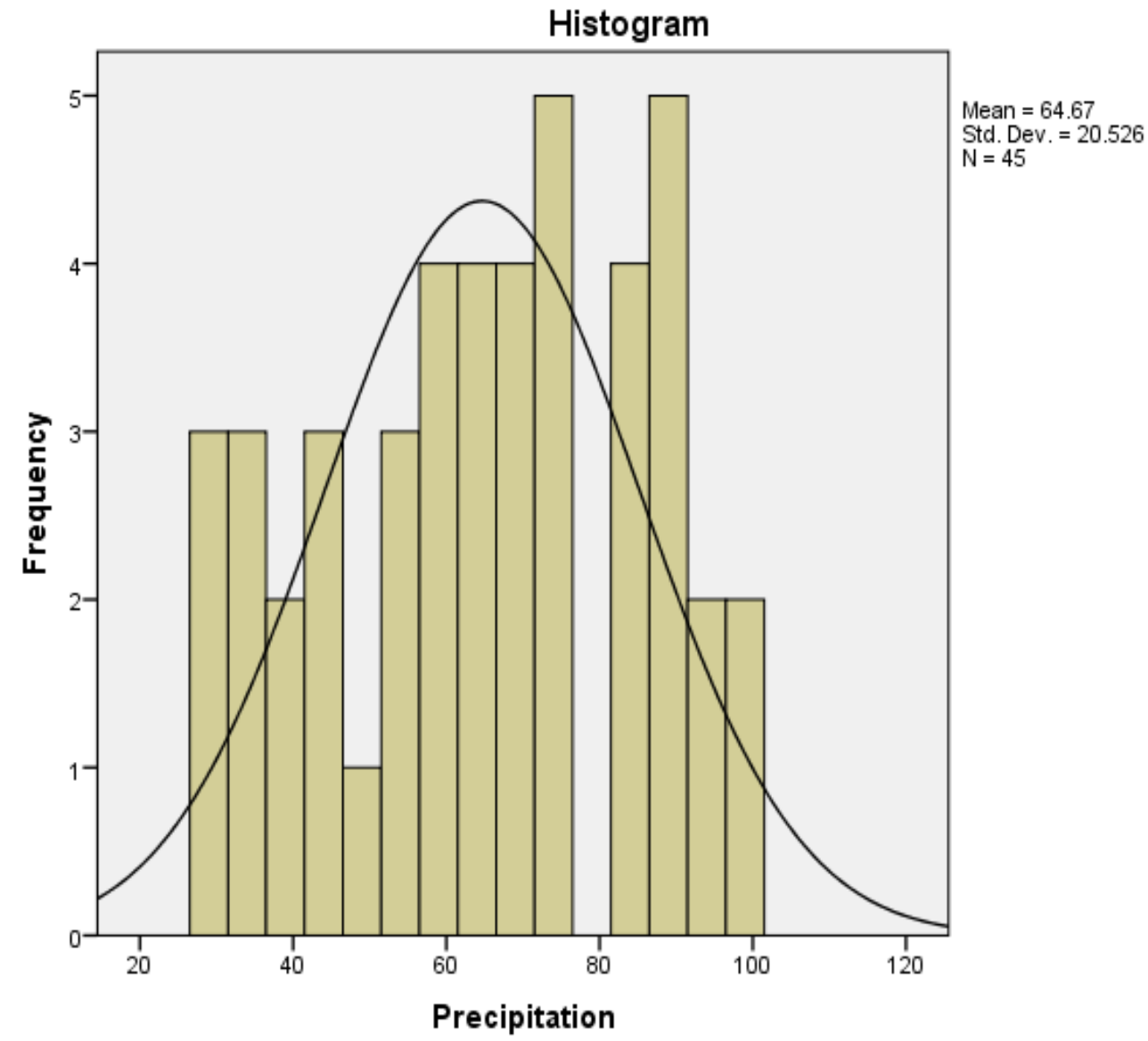

Figure 25. Descriptive statistics for precipitation. 
(7).

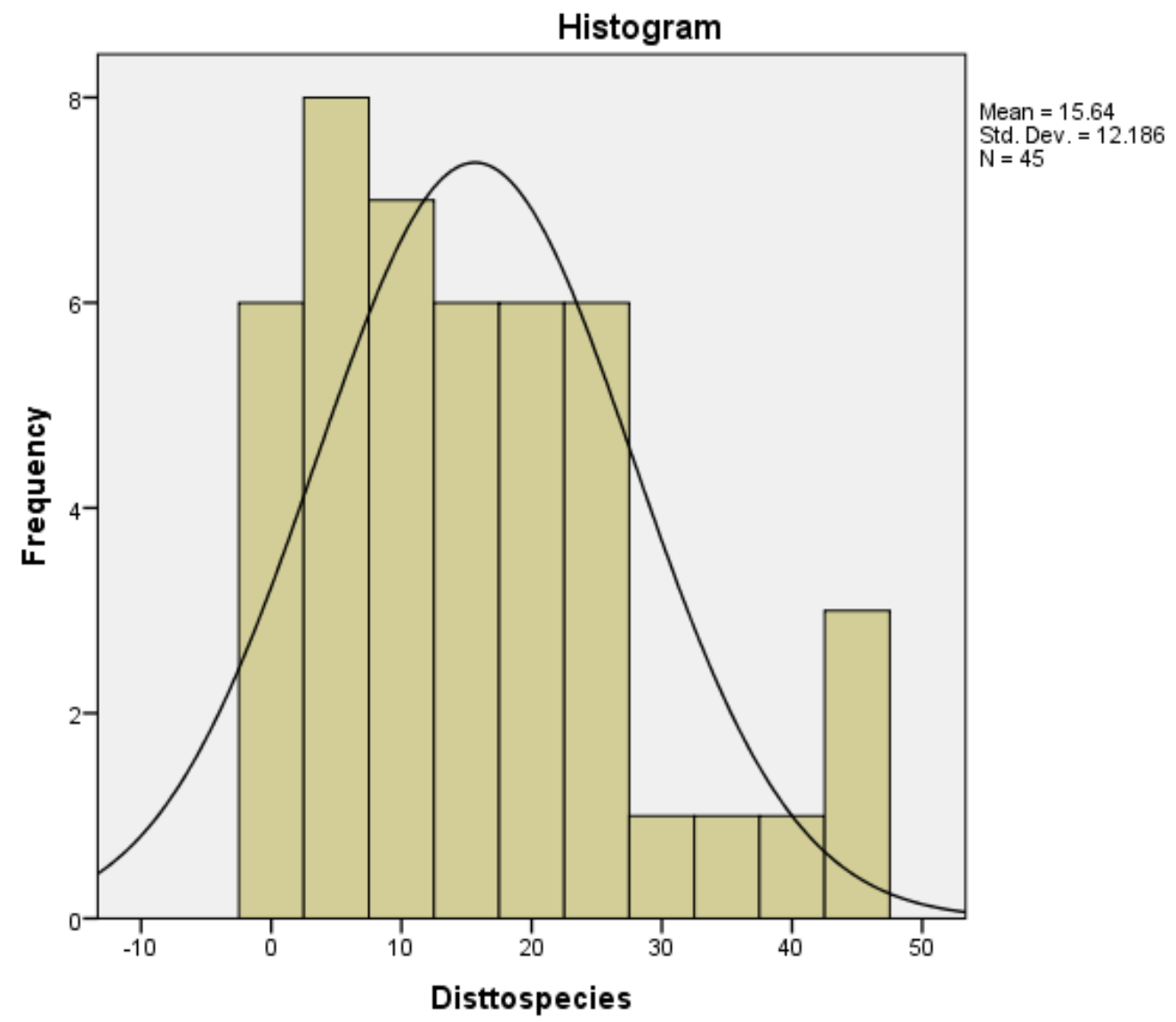

Figure 26. Descriptive statistics for distance to federally listed species. 
(8).

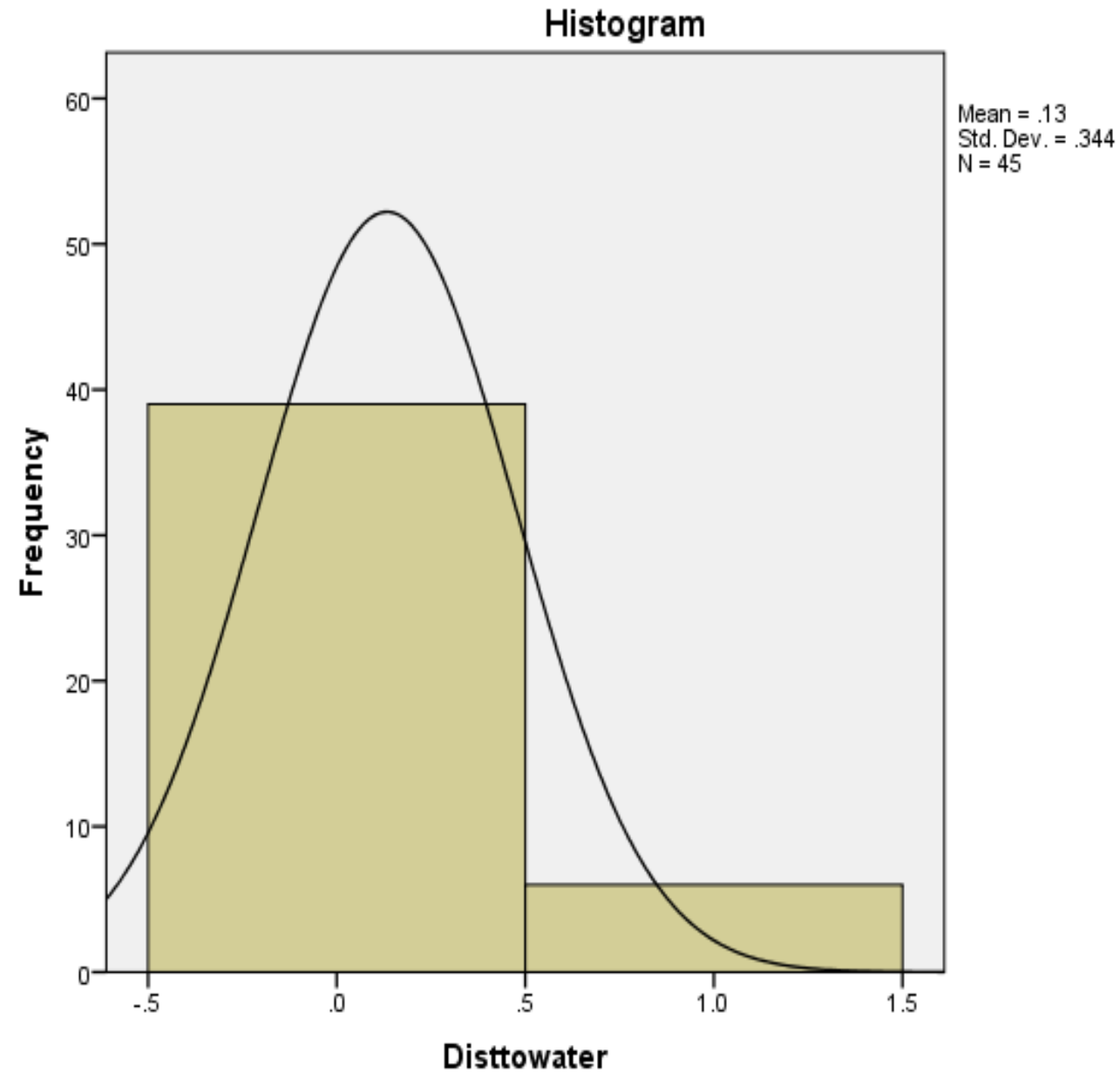

Figure 27. Descriptive statistics for distance to water. 
(9)

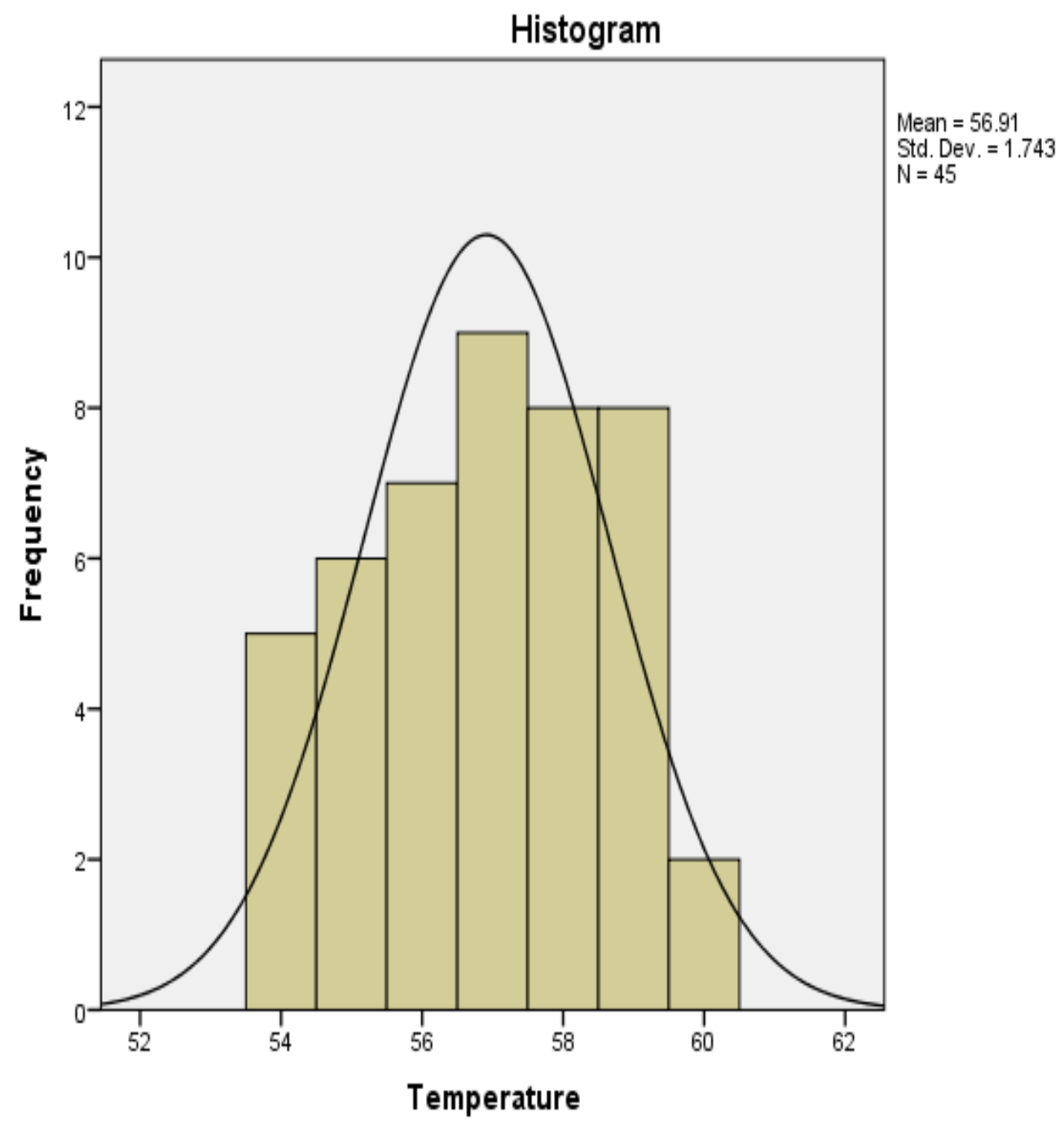

Figure 28. Descriptive statistics for temperature. 


\section{Appendix B: Distance Tables}

B8.

Nearest Neighbor Distance (NND) of The Peregrine Falcon Nest Sites

\begin{tabular}{cccccc}
\hline Sites & $\begin{array}{c}\text { Nearest } \\
\text { Neighbor } \\
\text { Site }\end{array}$ & $\begin{array}{c}\text { NND } \\
\text { (Miles) }\end{array}$ & Sites & $\begin{array}{c}\text { Nearest } \\
\text { Neighbor } \\
\text { Site }\end{array}$ & $\begin{array}{c}\text { NND } \\
\text { (Miles) }\end{array}$ \\
\hline 1 & 2 & 3 & 25 & 24 & 5 \\
2 & 1 & 3 & 26 & 45 & 3 \\
3 & 24 & 8 & 27 & 29 & 3 \\
4 & 36 & 10 & 28 & 31 & 4 \\
5 & 44 & 8 & 29 & 30 & 0 \\
6 & 23 & 1 & 30 & 32 & 0 \\
7 & 9 & 6 & 31 & 29 & 1 \\
8 & 7 & 7 & 32 & 30 & 0 \\
9 & 7 & 6 & 33 & 34 & 5 \\
10 & 19 & 7 & 34 & 33 & 5 \\
11 & 12 & 2 & 35 & 34 & 5 \\
12 & 11 & 2 & 36 & 4 & 10 \\
13 & 14 & 2 & 37 & 17 & 5 \\
14 & 13 & 2 & 38 & 41 & 5 \\
15 & 20 & 2 & 39 & 6 & 7 \\
16 & 20 & 3 & 40 & 28 & 6 \\
17 & 37 & 5 & 41 & 38 & 5 \\
18 & 15 & 3 & 42 & 40 & 8 \\
19 & 10 & 7 & 43 & 34 & 12 \\
20 & 15 & 2 & 44 & 5 & 8 \\
21 & 9 & 23 & 45 & 26 & 3 \\
22 & 24 & 9 & 46 & 26 & 8 \\
23 & 6 & 1 & 47 & 2 & 6 \\
24 & 25 & 5 & & & \\
\hline & & & & & \\
\hline
\end{tabular}


B9.

Distance of Peregrine Falcon Nest Sites to Sensitive Species Nest Sites

\begin{tabular}{|c|c|c|c|c|c|}
\hline $\begin{array}{c}\text { PEFA } \\
\text { Sites }\end{array}$ & $\begin{array}{c}\text { Listed } \\
\text { Species }\end{array}$ & $\begin{array}{c}\text { Distance } \\
\text { to Listed } \\
\text { Species } \\
\text { (miles) }\end{array}$ & $\begin{array}{c}\text { PEFA } \\
\text { Sites }\end{array}$ & $\begin{array}{c}\text { Listed } \\
\text { Species }\end{array}$ & $\begin{array}{c}\text { Distance } \\
\text { to } \\
\text { Listed } \\
\text { Species } \\
\text { (miles) } \\
\end{array}$ \\
\hline 1 & CLT2016 & 5 & 25 & SP2015A3N & 0 \\
\hline 2 & CLT2016 & 2 & 26 & SP2014R1 & 1 \\
\hline 3 & SP2016A22 & 8 & 27 & CLT2016 & 3 \\
\hline 4 & CLT2016 & 35 & 28 & CLT2016 & 5 \\
\hline 5 & CLT2016 & 19 & 29 & CLT2016 & 4 \\
\hline 6 & SP2014 & 14 & 30 & CLT2016 & 5 \\
\hline 7 & SP2014 & 27 & 31 & CLT2016 & 4 \\
\hline 8 & SP2014 & 25 & 32 & CLT2016 & 5 \\
\hline 9 & SNPL12016 & 23 & 33 & CLT2016 & 26 \\
\hline 10 & CLT2016 & 38 & 34 & CLT2016 & 23 \\
\hline 11 & CLT2016 & 45 & 35 & CLT2016 & 19 \\
\hline 12 & CLT2016 & 43 & 36 & CLT2016 & 43 \\
\hline 13 & CLT2016 & 10 & 37 & CLT2016 & 9 \\
\hline 14 & CLT2016 & 12 & 38 & SP2015R4 & 11 \\
\hline 15 & CLT2016 & 16 & 39 & SP2014 & 14 \\
\hline 16 & CLT2016 & 13 & 40 & CLT2016 & 11 \\
\hline 17 & CLT2016 & 12 & 41 & SP2015R4 & 6 \\
\hline 18 & CLT2016 & 18 & 42 & CLT2016 & 19 \\
\hline 19 & CLT2016 & 32 & 43 & CLT2016 & 25 \\
\hline 20 & CLT2016 & 14 & 44 & SP2016E12 & 22 \\
\hline 21 & SNPL12016 & 1 & 45 & SP2015R4 & 1 \\
\hline 22 & SP2016A13 & 10 & 46 & SP2016E16B & 0 \\
\hline 23 & SP2014 & 14 & 47 & CLT2016 & 7 \\
\hline 24 & SP2016A13 & 2 & & & \\
\hline
\end{tabular}


B10.

Distance of Peregrine Falcon Nest Sites to Water

\begin{tabular}{cccc}
\hline Site & $\begin{array}{c}\text { Distance } \\
\text { in Miles }\end{array}$ & Site & $\begin{array}{c}\text { Distance } \\
\text { in Miles }\end{array}$ \\
\hline 1 & 1 & 25 & 0 \\
2 & 0 & 26 & 0 \\
3 & 0 & 27 & 1 \\
4 & 0 & 28 & 0 \\
5 & 0 & 29 & 0 \\
6 & 1 & 30 & 0 \\
7 & 0 & 31 & 0 \\
8 & 0 & 32 & 1 \\
9 & 0 & 33 & 0 \\
10 & 0 & 34 & 0 \\
11 & 0 & 35 & 0 \\
12 & 0 & 36 & 0 \\
13 & 0 & 37 & 0 \\
14 & 0 & 38 & 0 \\
15 & 0 & 39 & 0 \\
16 & 0 & 40 & 0 \\
17 & 0 & 41 & 0 \\
18 & 0 & 42 & 0 \\
19 & 0 & 43 & 0 \\
20 & 0 & 44 & 0 \\
21 & 0 & 45 & 0 \\
22 & 1 & 46 & 0 \\
23 & 0 & 47 & 1 \\
24 & 1 & & \\
\hline & & &
\end{tabular}

B11.

Nest Site Categories

\begin{tabular}{lll}
\hline 1 & Bridges/Overpass & Anthro \\
2 & Power transmission towers/Cranes & Anthro \\
3 & Hillsides/Coastal Cliffs & Natural \\
4 & Buildings/Smoke Stacks & Anthro \\
\hline
\end{tabular}


B12.

Land Cover Codes from NLCD 2011 (Homer et al., 2015)

\footnotetext{
\begin{tabular}{rc}
\hline Value & Definition \\
\hline 11 & Open Water - All areas of open water, generally with less than
\end{tabular} $25 \%$ cover or vegetation or soil

12 Perennial Ice/Snow - All areas characterized by a perennial cover of ice and/or snow, generally greater than $25 \%$ of total cover.

21 Developed, Open Space - Includes areas with a mixture of some constructed materials, but mostly vegetation in the form of lawn grasses. Impervious surfaces account for less than 20 percent of total cover. These areas most commonly include large-lot single-family housing units, parks, golf courses, and vegetation planted in developed settings for recreation, erosion control, or aesthetic purposes.
}

22 Developed, Low Intensity -Includes areas with a mixture of constructed materials and vegetation. Impervious surfaces account for 20-49 percent of total cover. These areas most commonly include single-family housing units.

23 Developed, Medium Intensity - Includes areas with a mixture of constructed materials and vegetation. Impervious surfaces account for 50-79 percent of the total cover. These areas most commonly include single-family housing units.

24 Developed, High Intensity - Includes highly developed areas where people reside or work in high numbers. Examples include apartment complexes, row houses and commercial/industrial. Impervious surfaces account for 80 to 100 percent of the total cover.

31 Barren Land (Rock/Sand/Clay) - Barren areas of bedrock, desert pavement, scarps, talus, slides, volcanic material, glacial debris, sand dunes, strip mines, gravel pits and other accumulations of earthen material. Generally, vegetation accounts for less than $15 \%$ of total cover. 
41 Deciduous Forest - Areas dominated by trees generally greater than 5 meters tall, and greater than $20 \%$ of total vegetation cover. More than 75 percent of the tree species shed foliage simultaneously in response to seasonal change.

42 Evergreen Forest - Areas dominated by trees generally greater than 5 meters tall, and greater than $20 \%$ of total vegetation cover. More than 75 percent of the tree species maintain their leaves all year. Canopy is never without green foliage.

43 Mixed Forest - Areas dominated by trees generally greater than 5 meters tall, and greater than $20 \%$ of total vegetation cover. Neither deciduous nor evergreen species are greater than 75 percent of total tree cover.

51 Dwarf Scrub - Alaska only areas dominated by shrubs less than 20 centimeters tall with shrub canopy typically greater than $20 \%$ of total vegetation. This type is often co-associated with grasses, sedges, herbs, and non-vascular vegetation.

52 Shrub/Scrub - Areas dominated by shrubs; less than 5 meters tall with shrub canopy typically greater than $20 \%$ of total vegetation. This class includes true shrubs, young trees in an early successional stage or trees stunted from environmental conditions.

71 Grassland/Herbaceous - Areas dominated by graminoid or herbaceous vegetation, generally greater than $80 \%$ of total vegetation. These areas are not subject to intensive management such as tilling but can be utilized for grazing.

72 Sedge/Herbaceous - Alaska only areas dominated by sedges and forbs, generally greater than $80 \%$ of total vegetation. This type can occur with significant other grasses or other grass like plants, and includes sedge tundra, and sedge tussock tundra.

73 Lichens - Alaska only areas dominated by fruticose or foliose lichens generally greater than $80 \%$ of total vegetation.

74 Moss - Alaska only areas dominated by mosses, generally greater than $80 \%$ of total vegetation. 
81 Pasture/Hay - Areas of grasses, legumes, or grass-legume mixtures planted for livestock grazing or the production of seed or hay crops, typically on a perennial cycle. Pasture/hay vegetation accounts for greater than 20 percent of total vegetation.

82 Cultivated Crops - Areas used for the production of annual crops, such as corn, soybeans, vegetables, tobacco, and cotton, and also perennial woody crops such as orchards and vineyards. Crop vegetation accounts for greater than 20 percent of total vegetation. This class also includes all land being actively tilled.

90 Woody Wetlands - Areas where forest or shrub land vegetation accounts for greater than 20 percent of vegetative cover and the soil or substrate is periodically saturated with or covered with water.

95 Emergent Herbaceous Wetlands - Areas where perennial herbaceous vegetation accounts for greater than 80 percent of vegetative cover and the soil or substrate is periodically saturated with or covered with water. 


\section{Appendix C: Descriptive and Inferential Statistics Data}

C13.

Data Sheet for Descriptive and Inferential Statistics

\begin{tabular}{|c|c|c|c|c|c|c|c|c|c|c|c|c|}
\hline$\stackrel{\mathscr{B}}{=}$ & 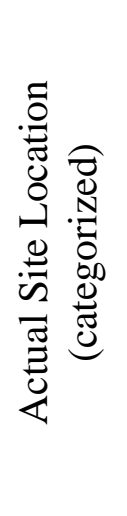 & 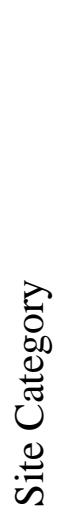 & 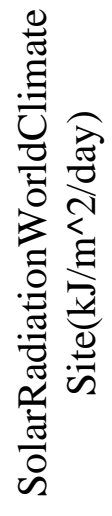 & 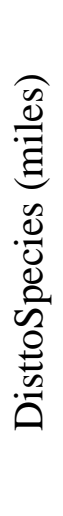 & 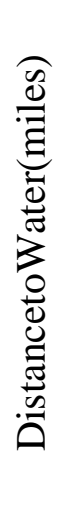 & 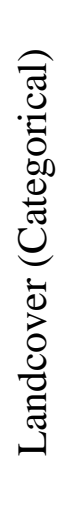 & 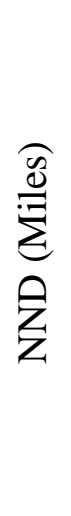 & 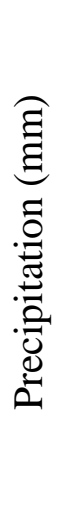 & 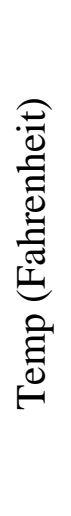 & 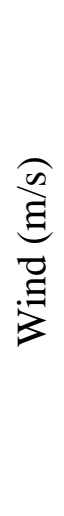 & 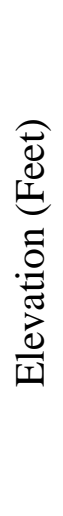 & $\begin{array}{l}\text { o̊ } \\
\text { o̊ } \\
\frac{0}{n}\end{array}$ \\
\hline-1 & $\neg$ & 总 & 呑 & 10 & $\neg$ & $N$ & $m$ & P & దొ & $\nabla$ & 슥 & $\nabla$ \\
\hline$\sim$ & $N$ & 完 & $\begin{array}{l}\text { 응 } \\
\text { ิㅡㅁ }\end{array}$ & $N$ & 0 & $N$ & $m$ & เ゙ & ద & $\nabla$ & $\stackrel{\curvearrowright}{\curvearrowright}$ & $\nabla$ \\
\hline$m$ & $m$ & $\begin{array}{l}\text { ్ㅗㅋ } \\
\text { 总 } \\
\text { Z }\end{array}$ & $\begin{array}{l}\text { حิ } \\
\text { 잉 } \\
\infty \\
-1\end{array}$ & $\infty$ & 0 & $m$ & $\infty$ & $\mathscr{q}$ & ณొ & $n$ & 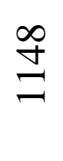 & ఉా \\
\hline$\nabla$ & - & $\begin{array}{l}\text { 을 } \\
\text { 莣 }\end{array}$ & $\begin{array}{l}- \\
\stackrel{\sigma}{1} \\
\infty \\
\infty \\
\rightarrow\end{array}$ & 매 & 0 & $\neg$ & $\stackrel{0}{-}$ & શิ & คి & $\nabla$ & $\ddot{m}$ & 0 \\
\hline L & $m$ & $\begin{array}{l}\text { त्ञ } \\
\text { 劳 } \\
\text { Z }\end{array}$ & $\begin{array}{l}\infty \\
\stackrel{\infty}{\infty} \\
\infty \\
\infty\end{array}$ & $\stackrel{\sigma}{\sigma}$ & 0 & $\nabla$ & $\infty$ & 号 & 沛 & $\nabla$ & ஜి & $\stackrel{\llcorner}{\sim}$ \\
\hline 0 & $m$ & $\begin{array}{l}\overline{7} \\
\text { 总 } \\
\text { Z }\end{array}$ & $\begin{array}{l}\text { న } \\
\stackrel{1}{1} \\
\infty \\
\sim\end{array}$ & $\underset{ت}{ت}$ & $\neg$ & $m$ & -1 & 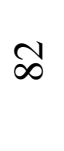 & ำ & $\nabla$ & 금 & $m$ \\
\hline
\end{tabular}




\begin{tabular}{|c|c|c|c|c|c|c|c|c|c|c|c|c|}
\hline$\Lambda$ & $m$ & $\begin{array}{l}\text { T्त्: } \\
\text { 䒿 } \\
\text { Z }\end{array}$ & 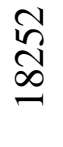 & $\widehat{\curvearrowright}$ & 0 & $\nabla$ & 0 & $\infty$ & 늠 & $\nabla$ & $\stackrel{\sim}{\text { مิ }}$ & ما \\
\hline$\infty$ & $m$ & $\begin{array}{l}\text { 营 } \\
\text { 䒿 } \\
\text { Z }\end{array}$ & $\begin{array}{l}\text { ஜ̂ } \\
\text { Oे }\end{array}$ & $\stackrel{\llcorner}{\sim}$ & 0 & $\nabla$ & $\Lambda$ & $\stackrel{n}{n}$ & 놈 & $\nabla$ & ষे & $\stackrel{\curvearrowright}{2}$ \\
\hline$a$ & $n$ & $\begin{array}{l}\text { 营 } \\
\text { 艺 }\end{array}$ & $\stackrel{\widehat{m}}{\stackrel{\infty}{\sigma}}$ & $\stackrel{\mathfrak{N}}{\sim}$ & 0 & $\nabla$ & 0 & $\underset{N}{ \pm}$ & மீ & $\nabla$ & ㄴํㅁ & $\stackrel{\bullet}{\sim}$ \\
\hline$\stackrel{0}{-1}$ & $m$ & $\begin{array}{l}\text { 苞 } \\
\text { 己 } \\
\text { 乙 }\end{array}$ & $\begin{array}{l}\text { 옹 } \\
\text { 금 }\end{array}$ & 饫 & 0 & - & $\Lambda$ & $\bar{\sigma}$ & ๒゙ & مו & $\stackrel{\infty}{\infty}$ & $\stackrel{2}{\longrightarrow}$ \\
\hline F & $m$ & 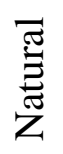 & 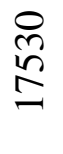 & $\stackrel{\varphi}{\forall}$ & 0 & $m$ & V & ஜ & 亡゙ & م & $\underset{\sim}{\stackrel{\Xi}{ }}$ & $\stackrel{\sim}{\sim}$ \\
\hline$\underset{\tau}{\sim}$ & $n$ & $\begin{array}{l}\text { 苞 } \\
\text { 己 } \\
\text { 乙 }\end{array}$ & 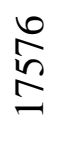 & $\mathscr{\vartheta}$ & 0 & $m$ & $\sim$ & $\infty$ & 노 & م & 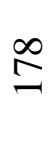 & $\stackrel{\mathscr{\gamma}}{\forall}$ \\
\hline$\stackrel{m}{\sim}$ & $m$ & $\begin{array}{l}\text { Tृ: } \\
\text { 䒿 } \\
\text { Z }\end{array}$ & 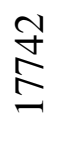 & $\stackrel{ }{-1}$ & 0 & $m$ & $\sim$ & 니 & ڤొ & $\nabla$ & fó & 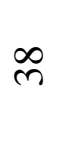 \\
\hline$\underset{ت}{\Xi}$ & $m$ & $\begin{array}{l}\text { 营 } \\
\text { 䒿 }\end{array}$ & $\begin{array}{l}\text { ல } \\
\stackrel{1}{\Lambda} \\
\end{array}$ & $\underset{\sim}{\sim}$ & 0 & $m$ & $\sim$ & $\underset{\infty}{\infty}$ & ம & $\nabla$ & $\stackrel{\infty}{\underset{\sim}{\sim}}$ & $\stackrel{\vartheta}{\forall}$ \\
\hline$\stackrel{\sim}{\sim}$ & $m$ & $\begin{array}{l}\underset{T}{\overparen{Z}} \\
\text { 䒿 } \\
\end{array}$ & $\begin{array}{l}\Re \\
\emptyset \\
\end{array}$ & $\stackrel{\sigma}{\sigma}$ & 0 & $m$ & $\sim$ & 며 & ம & $\nabla$ & চి & จ \\
\hline$\underline{\theta}$ & - & 芑 & $\begin{array}{l}\text { 공 } \\
\text { ㄱ }\end{array}$ & $\stackrel{n}{\sim}$ & 0 & 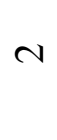 & $n$ & ஓ & ถิ & $\nabla$ & กิ & $\neg$ \\
\hline
\end{tabular}




\begin{tabular}{|c|c|c|c|c|c|c|c|c|c|c|c|c|}
\hline 그 & $\neg$ & 兑 & 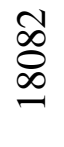 & $\stackrel{0}{-}$ & 0 & -1 & م & $\stackrel{\mathscr{N}}{N}$ & คి & $\nabla$ & 무 & $\nabla$ \\
\hline$\stackrel{\infty}{\sim}$ & $n$ & $\begin{array}{l}\underset{T}{\Xi} \\
\text { 䒿 }\end{array}$ & $\stackrel{ન}{\stackrel{ }{~}}$ & $\stackrel{\infty}{\sim}$ & 0 & $m$ & $m$ & g & 놈 & $\nabla$ & $\underset{n}{N}$ & $\hat{m}$ \\
\hline$\stackrel{\sigma}{-1}$ & $n$ & 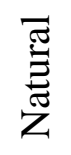 & $\begin{array}{l}\stackrel{-}{b} \\
\stackrel{0}{-1}\end{array}$ & $\tilde{n}$ & 0 & $m$ & $\Lambda$ & â & เ゙ & م & ๙ૅ & nิ \\
\hline$\stackrel{\curvearrowright}{ }$ & $m$ & $\begin{array}{l}\text { 즐 } \\
\text { 坖 }\end{array}$ & 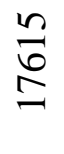 & $\underset{\exists}{\Xi}$ & 0 & $m$ & $\sim$ & శ઼ & ڤొ & $\nabla$ & ฆี & 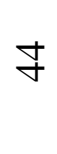 \\
\hline $\bar{\sim}$ & $\nabla$ & 芑 & $\begin{array}{l}\mathbb{N} \\
\stackrel{0}{0} \\
\infty \\
-1\end{array}$ & -1 & 0 & $N$ & $\stackrel{\sim}{\sim}$ & g & ம & $\nabla$ & ஓ & -1 \\
\hline$\approx$ & $\nabla$ & 总 & $\underset{\substack{\infty \\
\infty \\
\infty}}{\infty}$ & $\stackrel{ }{\circ}$ & -1 & $\sim$ & $\sigma$ & $\stackrel{\mathscr{n}}{m}$ & 8 & $\nabla$ & $\stackrel{\infty}{m}$ & - \\
\hline$\stackrel{\sim}{N}$ & $n$ & 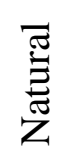 & $\begin{array}{l}\infty \\
\stackrel{2}{2} \\
\infty \\
\infty\end{array}$ & $\underset{ت}{ \pm}$ & 0 & $\nabla$ & - & $\infty$ & 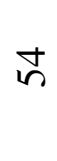 & $m$ & $\stackrel{\infty}{\stackrel{\infty}{\circ}}$ & $\vec{m}$ \\
\hline$\stackrel{\nabla}{\sim}$ & N & 兑 & 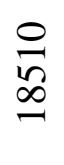 & $\sim$ & -1 & -1 & م & $\stackrel{2}{ }$ & ค) & $\nabla$ & œ & 0 \\
\hline$\stackrel{\llcorner}{\sim}$ & N & 兑 & $\begin{array}{l}\text { బิ } \\
\text { م } \\
\text { - }\end{array}$ & 0 & 0 & -1 & م & $\vec{n}$ & ก) & $\nabla$ & 8 & 0 \\
\hline$\stackrel{\vartheta}{v}$ & $\neg$ & 总 & $\stackrel{\text { 음 }}{\underset{-1}{-1}}$ & -1 & 0 & $\sim$ & $m$ & $\stackrel{m}{m}$ & مิ & $\nabla$ & $\stackrel{n}{N}$ & 0 \\
\hline
\end{tabular}




\begin{tabular}{|c|c|c|c|c|c|c|c|c|c|c|c|c|}
\hline$\stackrel{\infty}{\sim}$ & $\sim$ & 芑 & 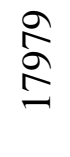 & م & 0 & -1 & $\nabla$ & $\stackrel{\infty}{\infty}$ & 冓 & $\nabla$ & $\stackrel{\stackrel{N}{m}}{\stackrel{n}{n}}$ & $\nabla$ \\
\hline 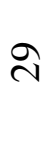 & $\nabla$ & 总 & $\begin{array}{l}\text { N } \\
\text { N } \\
\text { N }\end{array}$ & $\nabla$ & 0 & 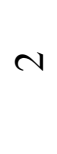 & 0 & 느 & డొ & $\nabla$ & $\stackrel{\text { ஜீ }}{8}$ & - \\
\hline ஓ & $\nabla$ & 总 & 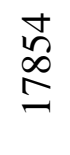 & م & 0 & $\sim$ & 0 & $\mathscr{ఠ}$ & ถิ & $\nabla$ & 尺̊ & - \\
\hline $\bar{m}$ & $V$ & 芑 & $\begin{array}{l}\text { ని } \\
\infty \\
\end{array}$ & $\nabla$ & 0 & $\sim$ & $\neg$ & שె & ถิ & $\nabla$ & $\underset{\exists}{\Xi}$ & 0 \\
\hline กิ & $\nabla$ & 总 & $\begin{array}{l}\hat{\infty} \\
\hat{x} \\
\text { ㄱ. }\end{array}$ & ما & $\neg$ & 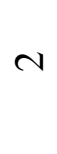 & 0 & $\mathscr{ఠ}$ & ถิ & $\nabla$ & Бे & - \\
\hline$m$ & $m$ & $\begin{array}{l}\overline{\widetilde{J}} \\
\text { Z } \\
\text { Z }\end{array}$ & 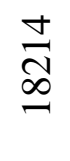 & $\stackrel{\bullet}{\sim}$ & 0 & $m$ & م & రु & ถิ & $\nabla$ & $\underset{\overbrace{}}{\stackrel{\Xi}{8}}$ & $\approx$ \\
\hline ले & -1 & 总 & $\begin{array}{l}\text { 오 } \\
\text { న } \\
\text { - }\end{array}$ & $\stackrel{\sim}{N}$ & 0 & -1 & م & 8 & คి & $\nabla$ & n & 0 \\
\hline மூ & -1 & 呈 & 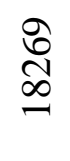 & $\stackrel{\sigma}{\sigma}$ & 0 & $\sim$ & م & คุ & ค่ & $\nabla$ & ตै & 0 \\
\hline$\stackrel{\varphi}{m}$ & $\neg$ & 呈 & 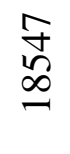 & $\stackrel{\mathscr{\vartheta}}{\forall}$ & 0 & $\sim$ & $\stackrel{0}{-1}$ & $\stackrel{\text { ㅁ }}{n}$ & คุ & $m$ & $\stackrel{\llcorner}{\sim}$ & 0 \\
\hline$\hat{m}$ & $v$ & 兑 & 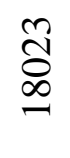 & $a$ & 0 & $\neg$ & م & $\mathscr{\wp}$ & $\varnothing$ & $\nabla$ & $\stackrel{\infty}{\vec{N}}$ & N \\
\hline
\end{tabular}




\begin{tabular}{|c|c|c|c|c|c|c|c|c|c|c|c|c|}
\hline$\infty$ & $\neg$ & 兑 & 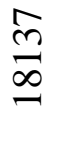 & $\exists$ & 0 & $\nabla$ & م & ถิ & คุ & $\nabla$ & 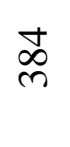 & คి \\
\hline ले & $m$ & $\begin{array}{l}\text { 즐 } \\
\text { 坖 } \\
\text { Z }\end{array}$ & $\begin{array}{l}0 \\
\stackrel{1}{-1} \\
\underset{\sigma}{-1}\end{array}$ & $\underset{\Xi}{\Xi}$ & 0 & $\nabla$ & $\Lambda$ & $\stackrel{\circ}{\Omega}$ & ம & $\nabla$ & த্ & $\underline{\sim}$ \\
\hline ஓ & $\nabla$ & 克 & 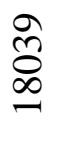 & ન & 0 & $\sim$ & 0 & กิ & ㄴำ & $\nabla$ & $\underset{\sim}{\sim}$ & 0 \\
\hline 守 & $\nabla$ & 号 & $\underset{\infty}{\stackrel{m}{+}}$ & 0 & 0 & $\sim$ & L & $\stackrel{\dddot{\vartheta}}{\forall}$ & ถิ & $\nabla$ & $\stackrel{\nabla}{\stackrel{\nu}{~}}$ & - \\
\hline テ & $m$ & $\begin{array}{l}\text { 즐 } \\
\text { 坖 } \\
\text { Z }\end{array}$ & 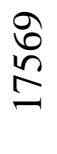 & 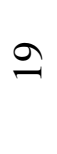 & 0 & $n$ & $\infty$ & 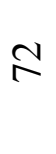 & œొ & $\nabla$ & $\begin{array}{c}m \\
\infty \\
m\end{array}$ & $\stackrel{m}{ }$ \\
\hline$\stackrel{\mathscr{\gamma}}{\forall}$ & $\neg$ & 克 & 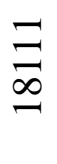 & $\stackrel{\llcorner}{\sim}$ & 0 & $\neg$ & $\underset{\sim}{\sim}$ & $\mathbb{N}$ & ڤั & $\nabla$ & $\infty$ & 0 \\
\hline ষ & $m$ & 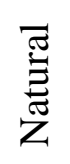 & $\begin{array}{l}0 \\
\stackrel{+}{\infty} \\
\sim\end{array}$ & ฟ & 0 & $\nabla$ & $\infty$ & ڤొ & œొ & $n$ & $\underset{\sim}{\stackrel{ \pm}{\sim}}$ & $\stackrel{\infty}{\sim}$ \\
\hline$\stackrel{\leftrightarrow}{\forall}$ & $\sim$ & 总 & $\begin{array}{l}\stackrel{-}{\mathscr{2}} \\
\stackrel{\infty}{\rightarrow}\end{array}$ & $\neg$ & 0 & $\neg$ & $m$ & $\infty$ & ถิ & $\nabla$ & ஓ & $m$ \\
\hline $\mathscr{f}$ & $\sim$ & 总 & 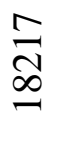 & 0 & 0 & $\neg$ & $\infty$ & $\hat{m}$ & 赵 & $\nabla$ & ஓి & 0 \\
\hline$\stackrel{\gamma}{\sigma}$ & $\nabla$ & 总 & $\stackrel{\text { 늠 }}{\overbrace{\infty}}$ & $\Lambda$ & $\neg$ & $\sim$ & 0 & ำ & ஸొ & $\nabla$ & 옹 & ص \\
\hline
\end{tabular}




\section{Appendix D: PCA Data}

D14.

Data Sheet for PCA

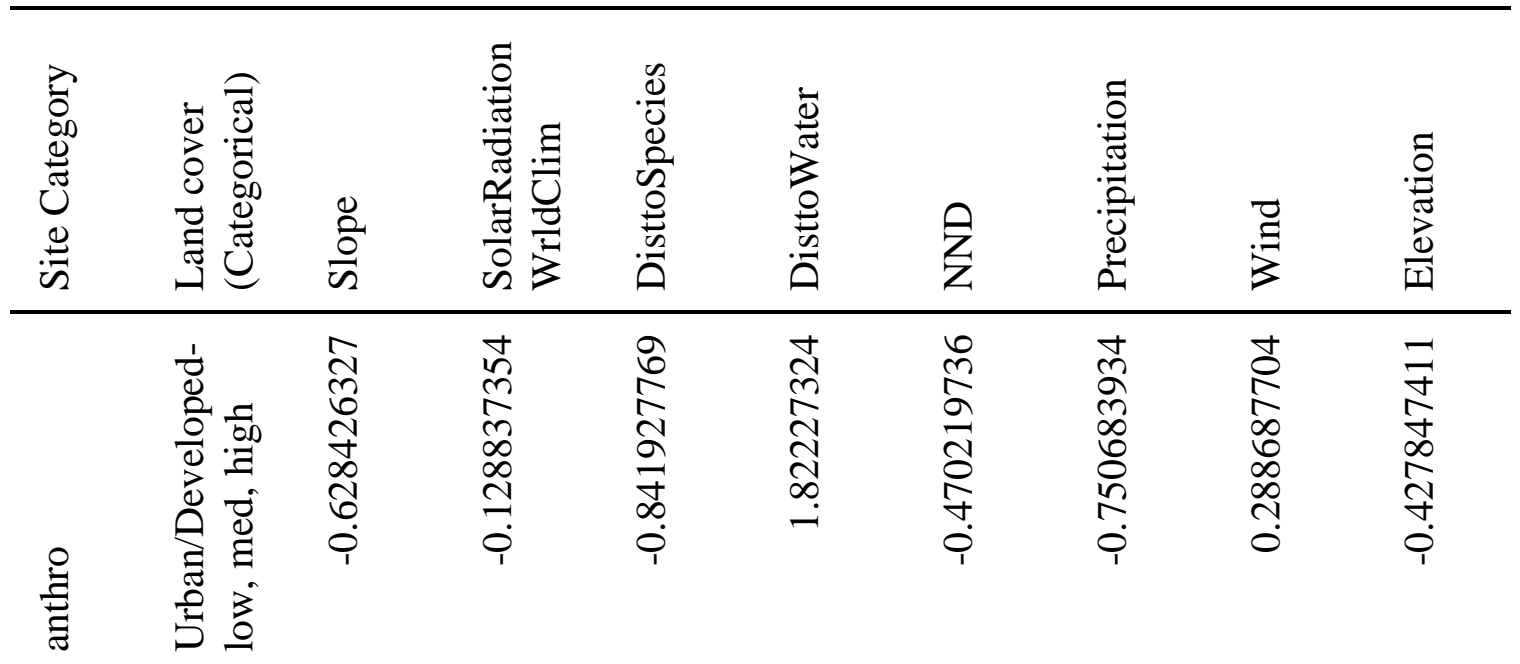

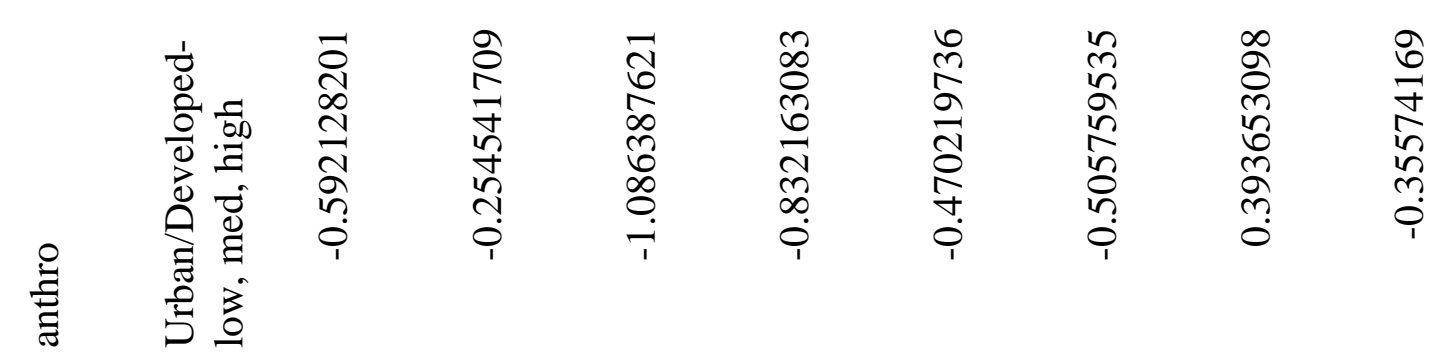

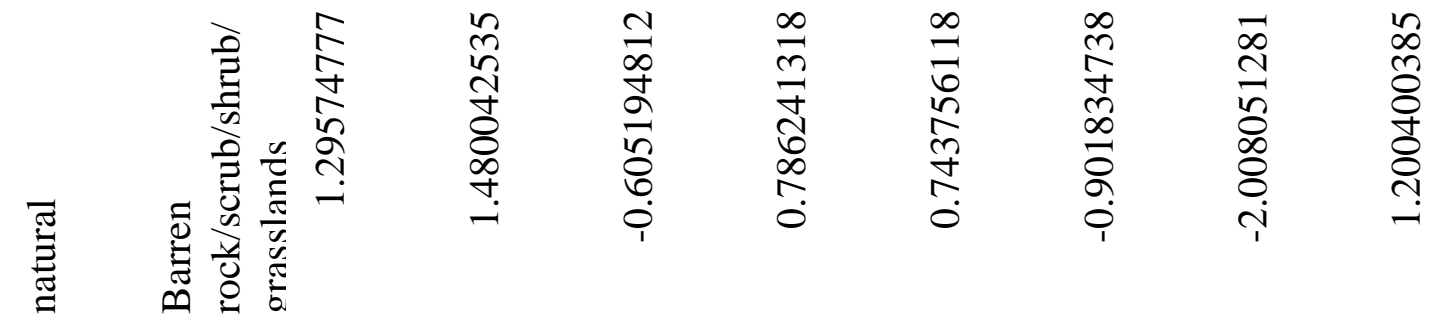

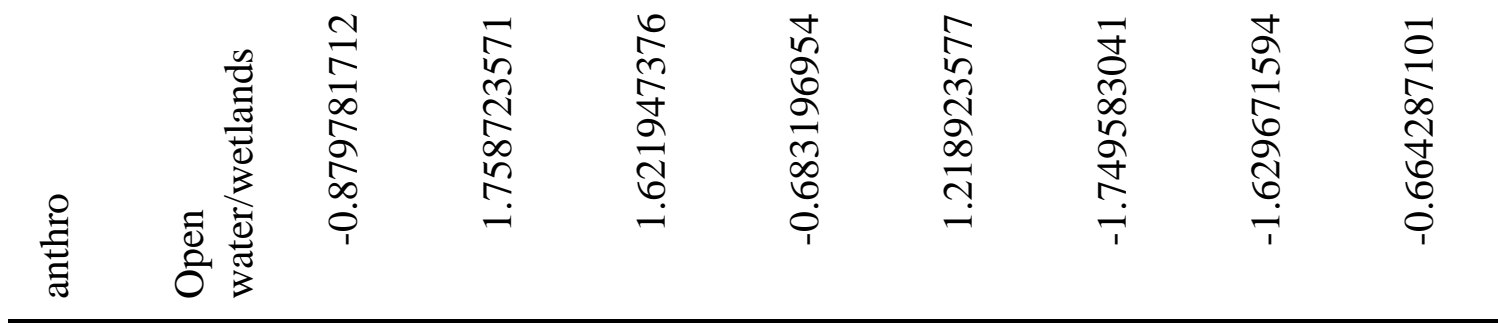




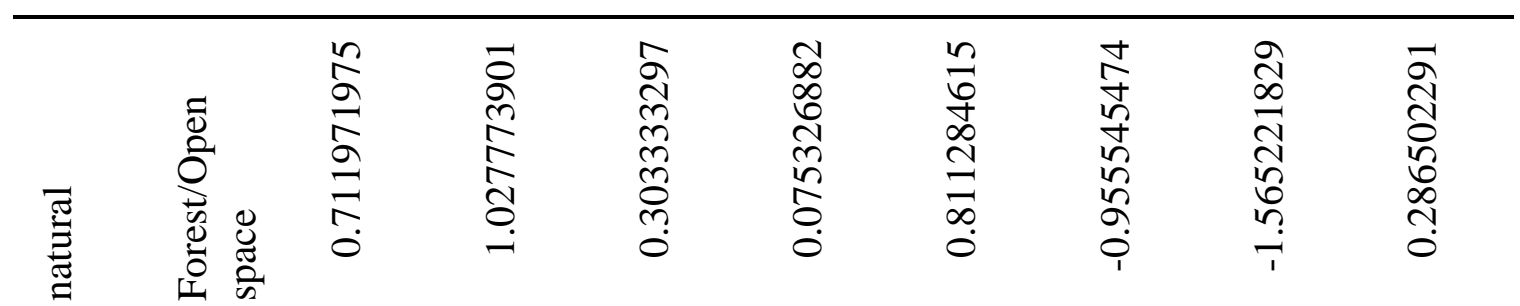

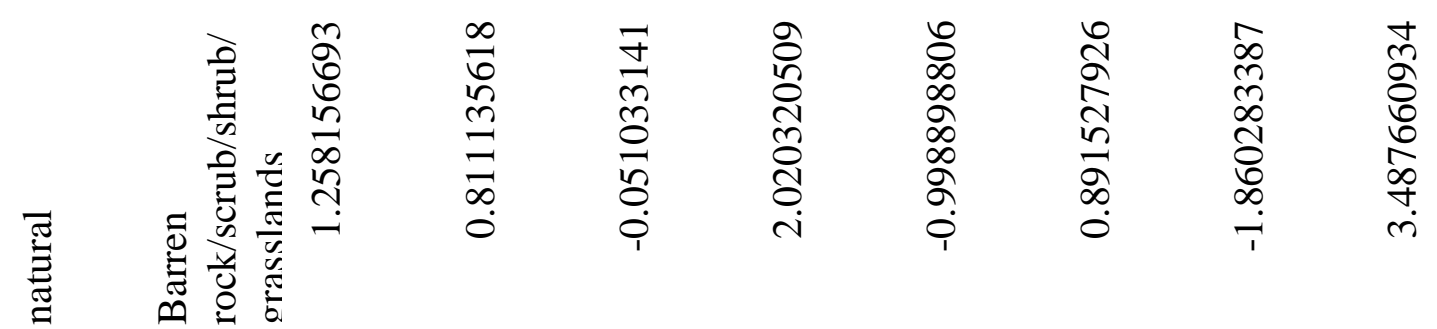

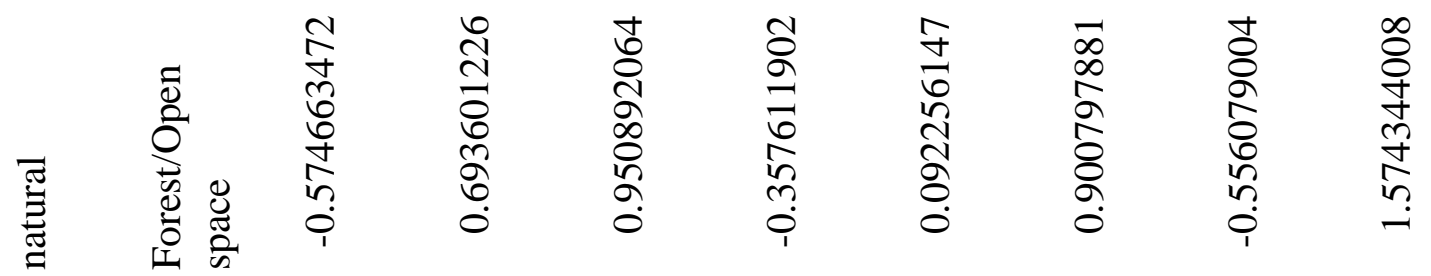

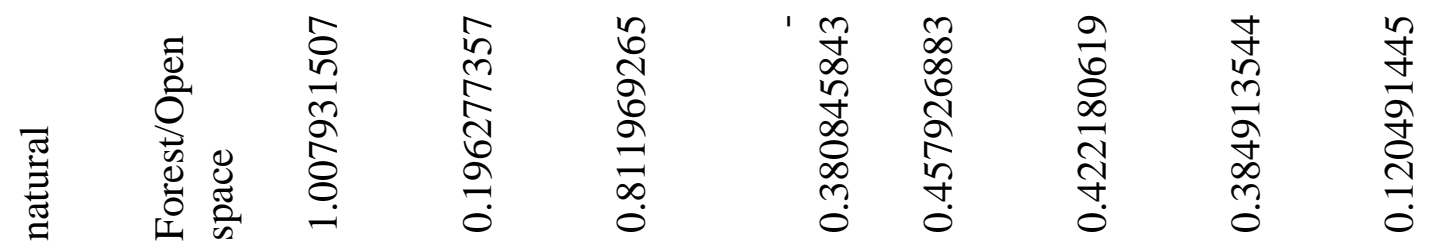

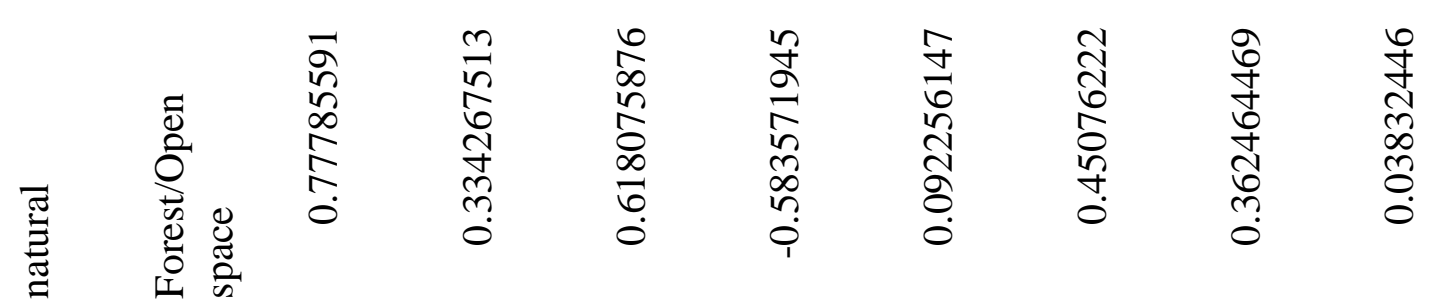

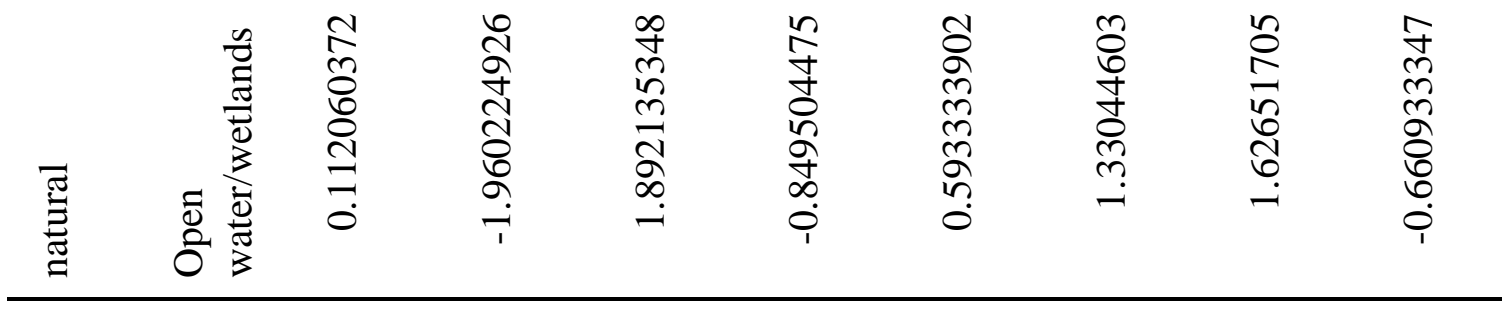




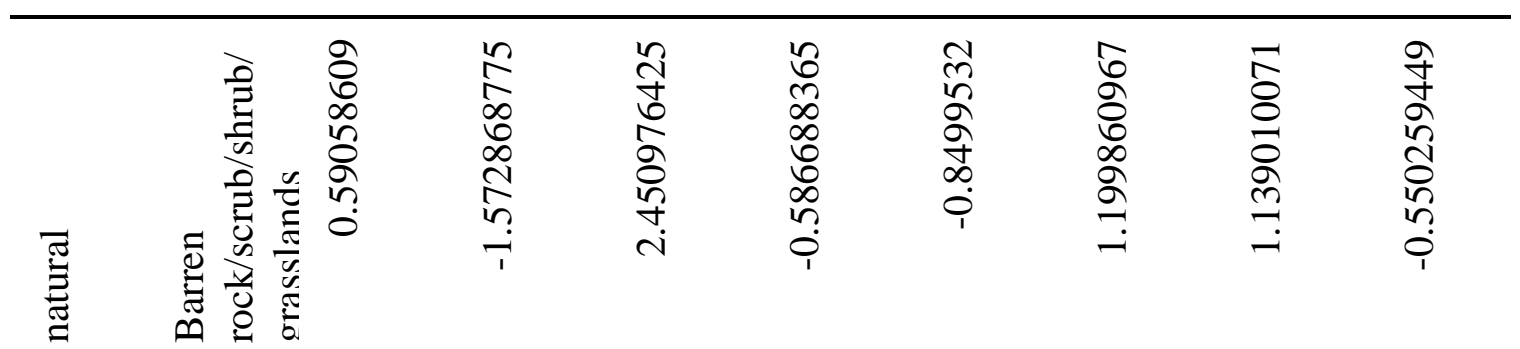

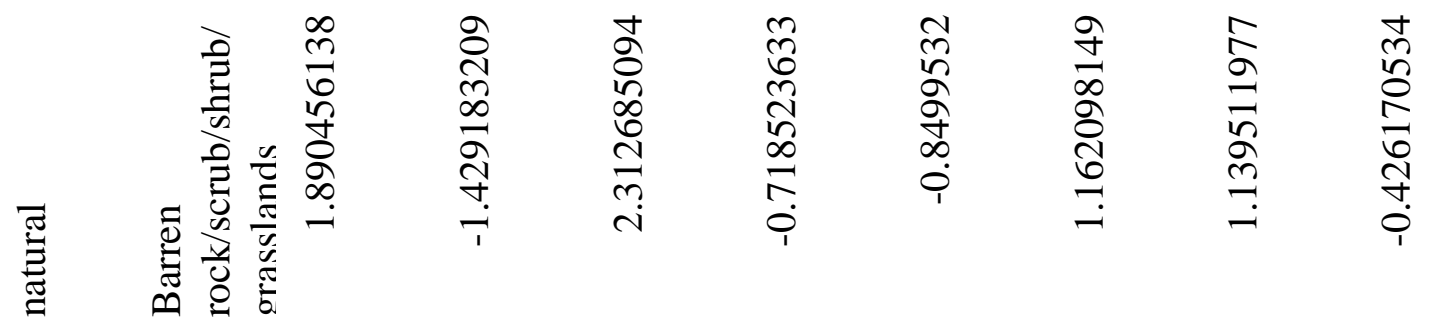

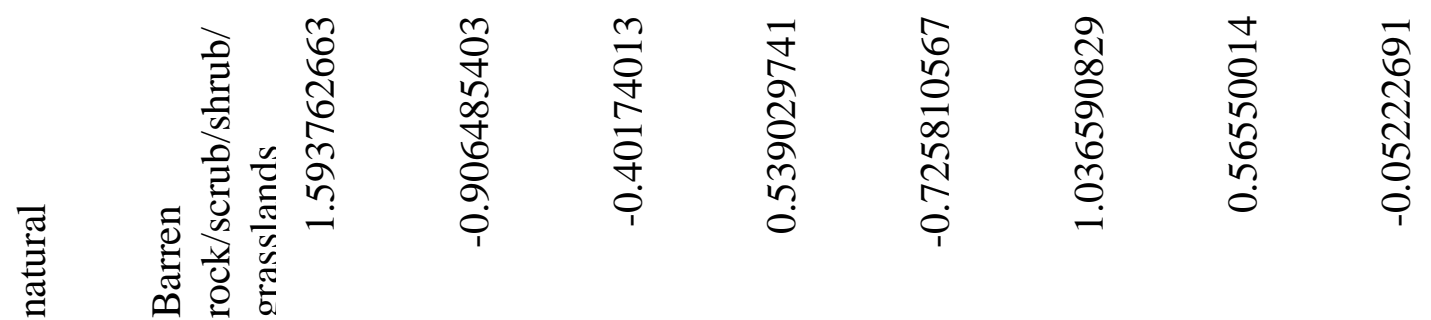

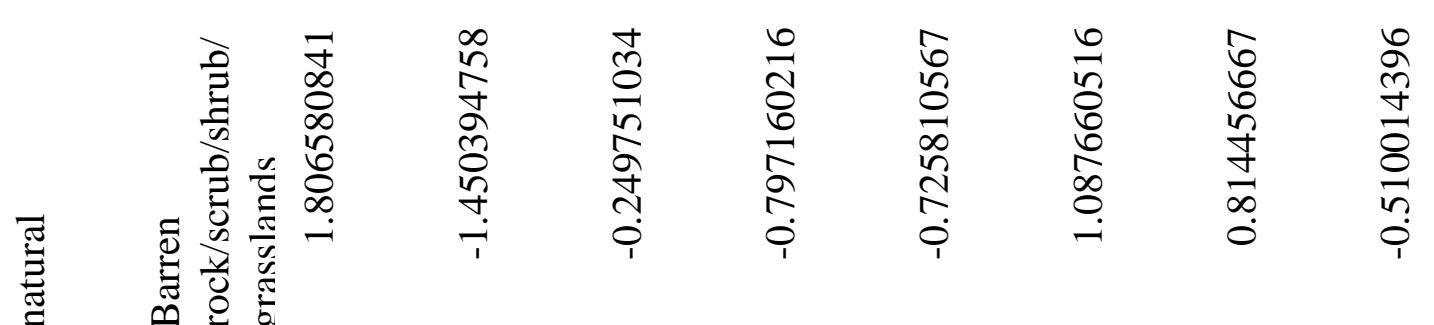
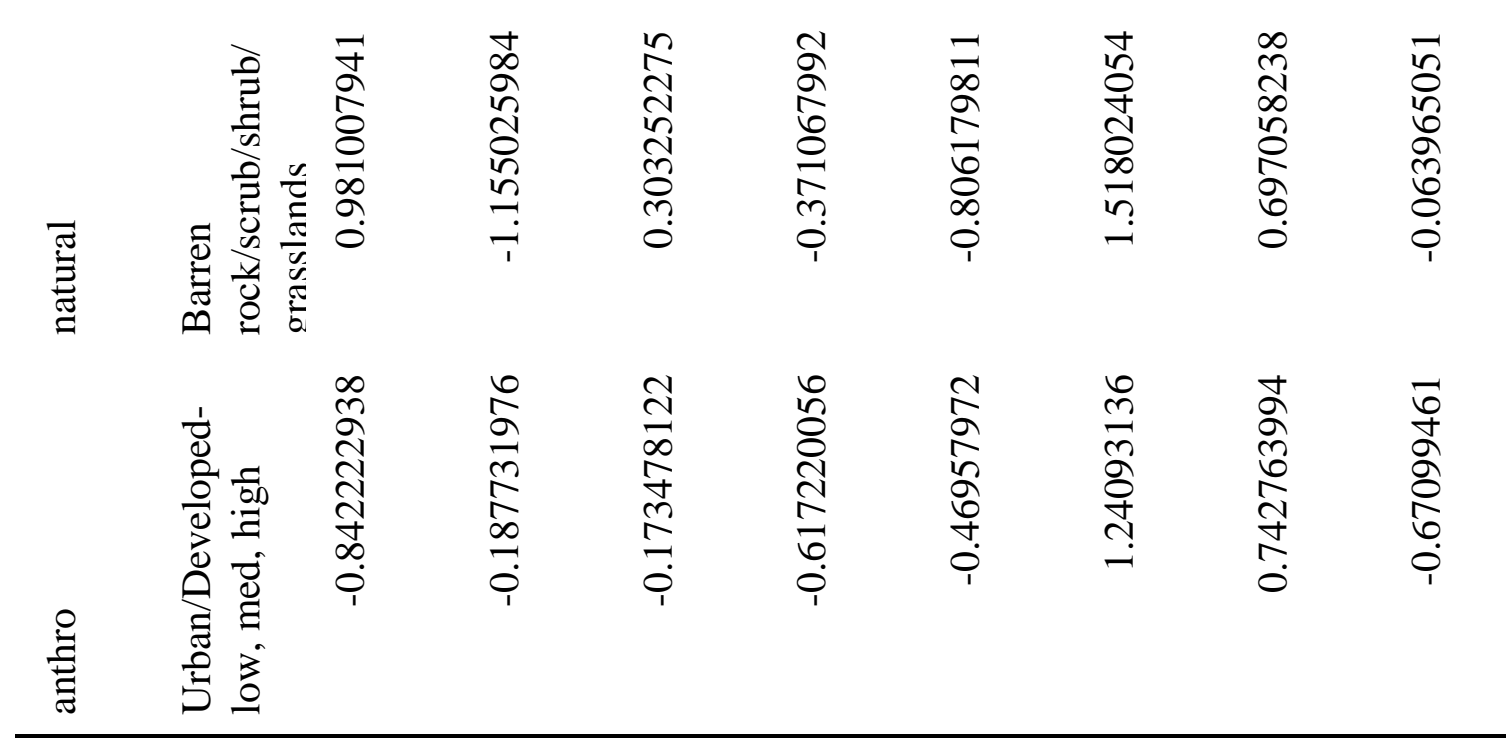

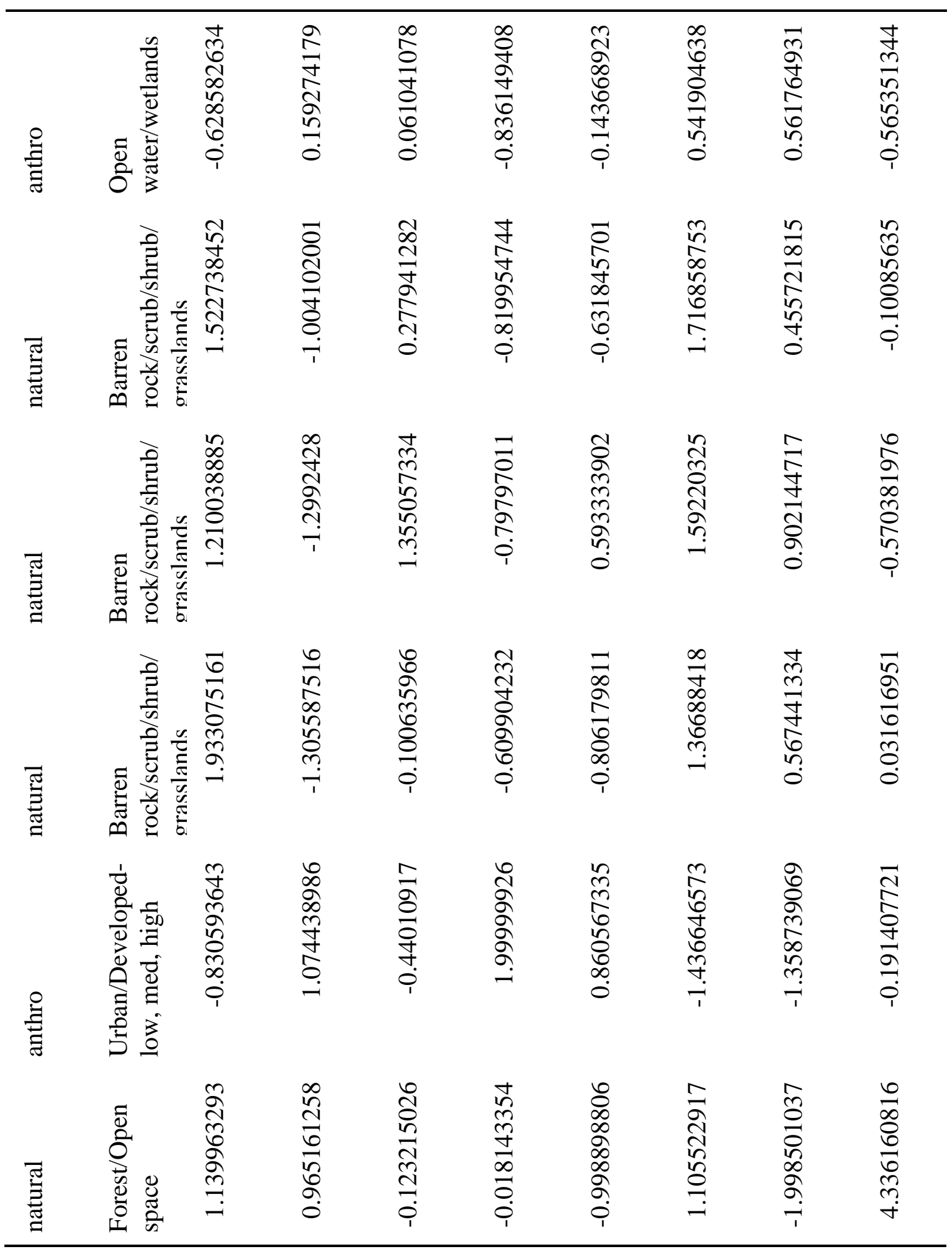


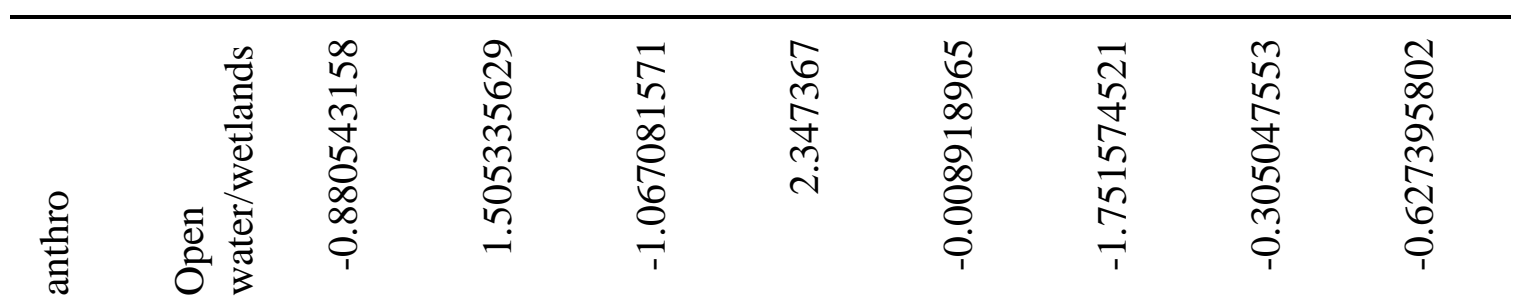

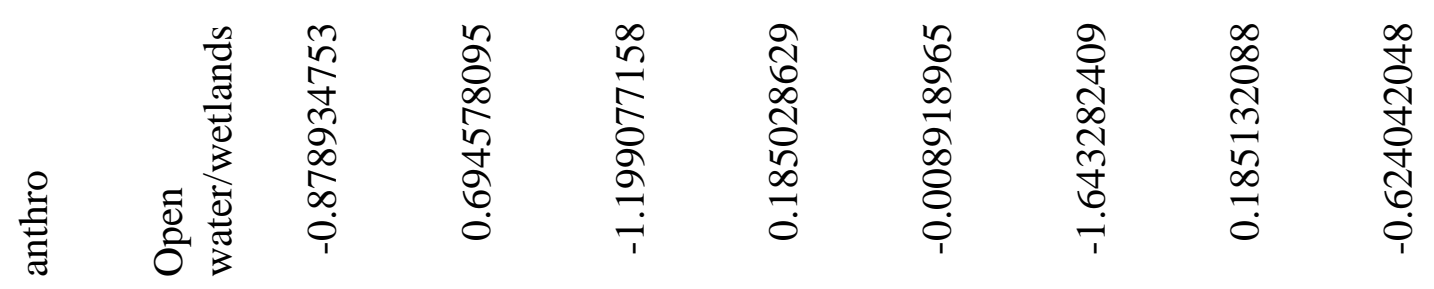

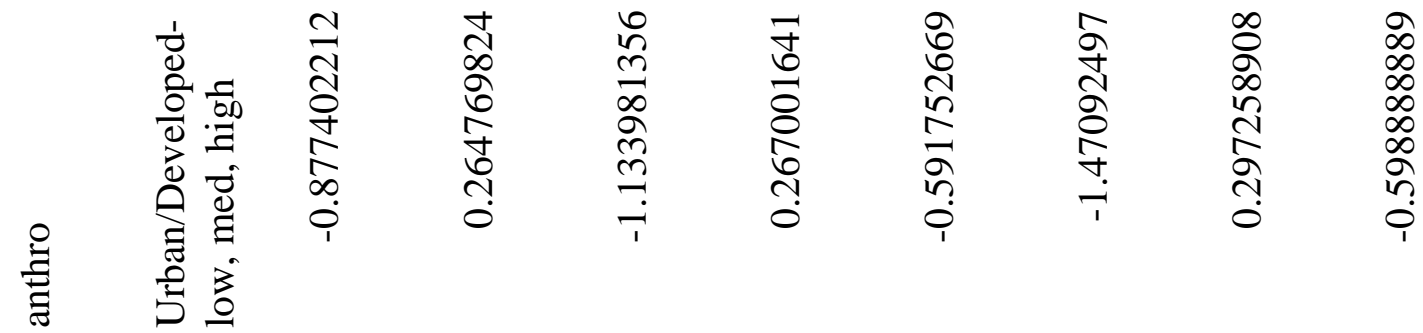

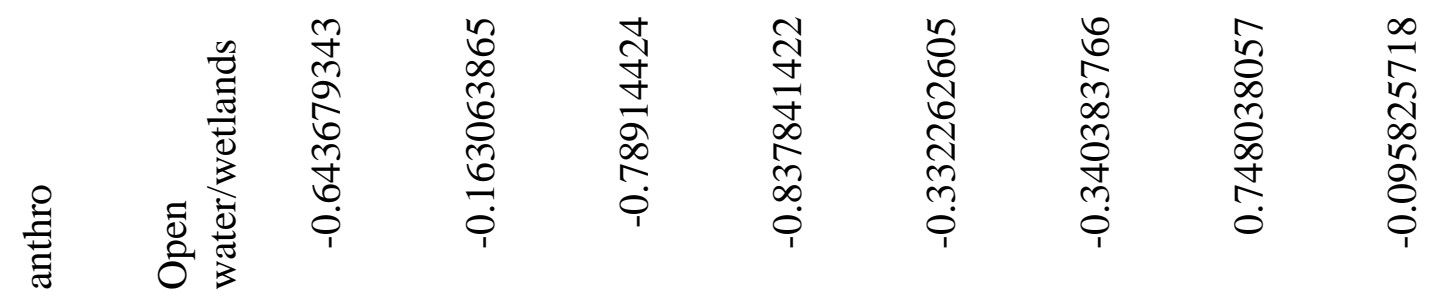

\begin{tabular}{|c|c|c|c|c|c|c|c|}
\hline 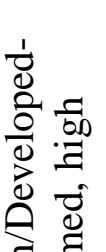 & 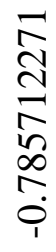 & 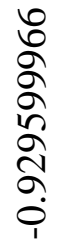 & 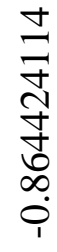 & 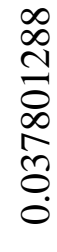 & 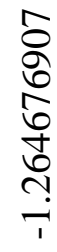 & 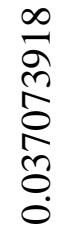 & 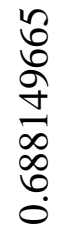 \\
\hline
\end{tabular}

总营总

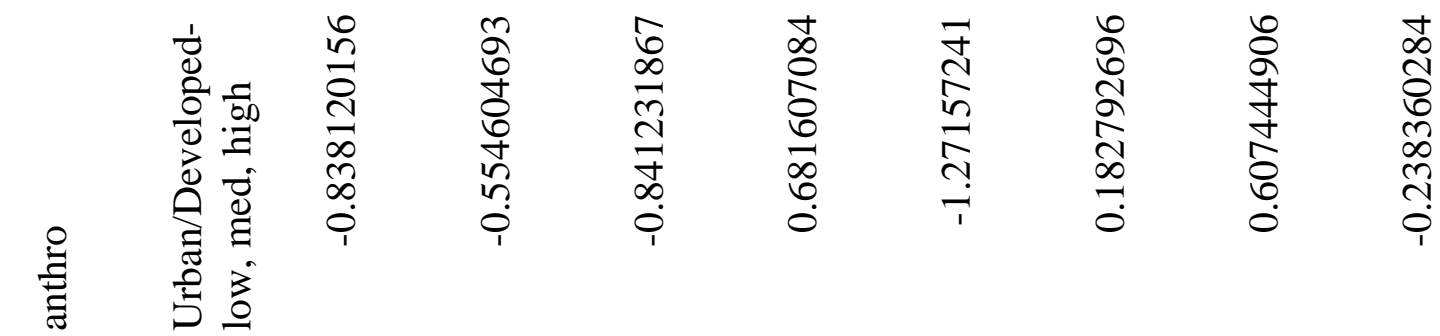




\begin{tabular}{|c|c|c|c|c|c|c|c|c|c|}
\hline $\begin{array}{l}\text { 을 } \\
\text { 范 }\end{array}$ & 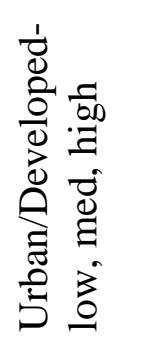 & 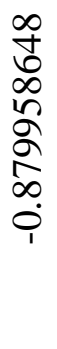 & 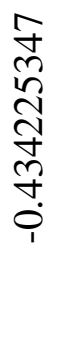 & $\begin{array}{l}0 \\
0 \\
0 \\
\infty \\
\infty \\
\infty \\
0 \\
0 \\
1\end{array}$ & 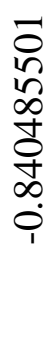 & 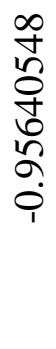 & 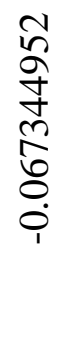 & $\begin{array}{l}-1 \\
m \\
\hat{0} \\
0 \\
\delta \\
8 \\
0 \\
0\end{array}$ & 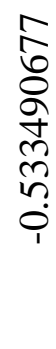 \\
\hline $\begin{array}{l}\text { 单 } \\
\text { 䒕 }\end{array}$ & 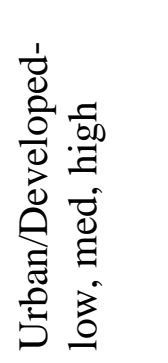 & 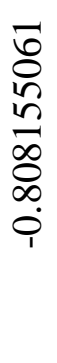 & 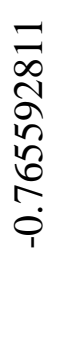 & 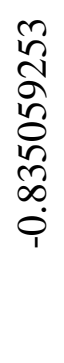 & 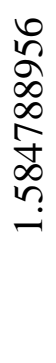 & 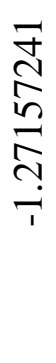 & $\begin{array}{l}N \\
10 \\
0 \\
00 \\
0 \\
\infty \\
0 \\
0\end{array}$ & 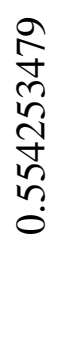 & 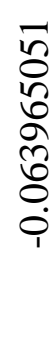 \\
\hline $\begin{array}{l}\bar{Z} \\
\text { Z } \\
\text { Z }\end{array}$ & 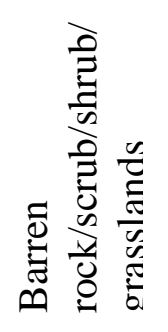 & 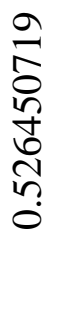 & 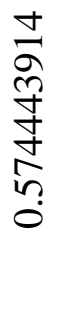 & 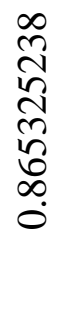 & 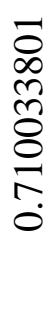 & 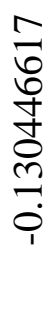 & 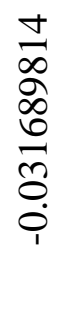 & 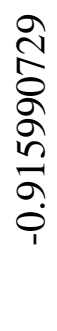 & 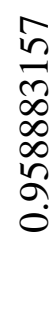 \\
\hline 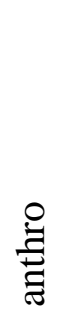 & 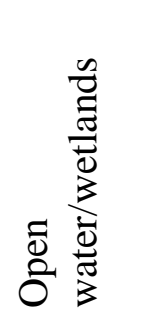 & 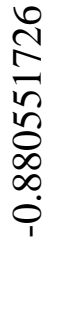 & 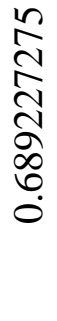 & 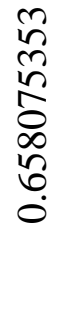 & 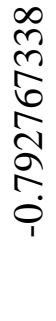 & 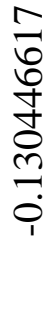 & 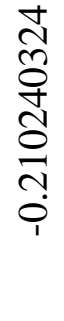 & 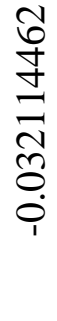 & 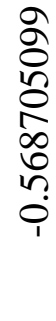 \\
\hline $\begin{array}{l}\text { 号 } \\
\text { 䓫 }\end{array}$ & 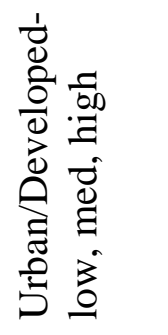 & 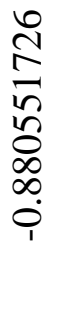 & 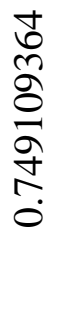 & $\begin{array}{l}\text { L } \\
\infty \\
10 \\
\infty \\
0 \\
10 \\
0 \\
0 \\
0\end{array}$ & 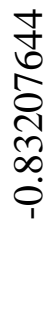 & 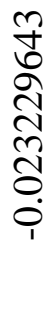 & 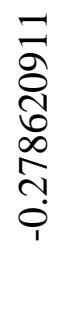 & 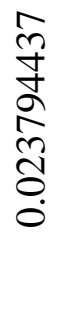 & 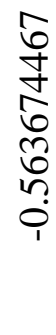 \\
\hline
\end{tabular}




\begin{tabular}{|c|c|c|c|c|c|c|c|c|c|}
\hline 芑 & 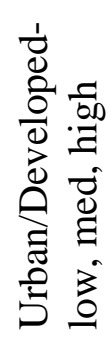 & 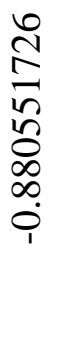 & 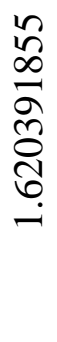 & 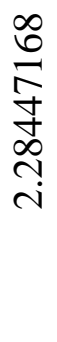 & 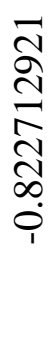 & 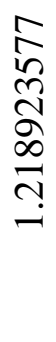 & 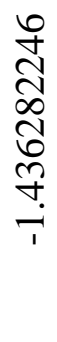 & $\begin{array}{l}-1 \\
0 \\
0 \\
0 \\
0 \\
8 \\
0 \\
\\
\end{array}$ & 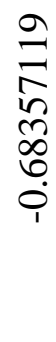 \\
\hline 总 & 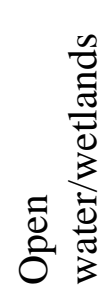 & 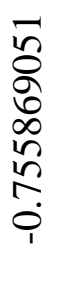 & 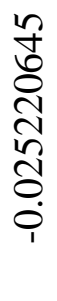 & 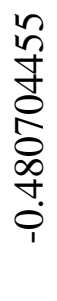 & 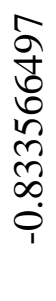 & 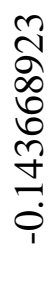 & $\begin{array}{l}\infty \\
0 \\
\infty \\
\infty \\
01 \\
\stackrel{1}{N} \\
\\
\stackrel{0}{0}\end{array}$ & 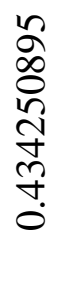 & 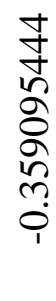 \\
\hline 芫 & 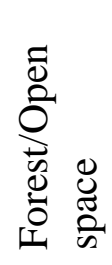 & 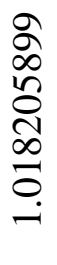 & 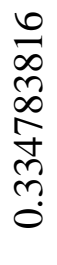 & 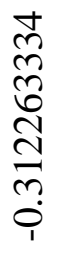 & 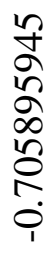 & 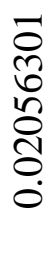 & 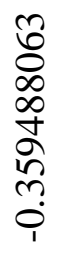 & 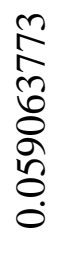 & 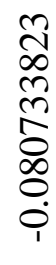 \\
\hline $\begin{array}{l}\bar{T} \\
\stackrel{\Xi}{\Xi} \\
\stackrel{\Xi}{\Xi}\end{array}$ & 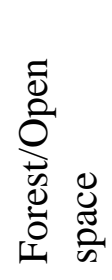 & $\begin{array}{l}\infty \\
\tilde{\sigma} \\
\infty \\
\infty \\
0 \\
\stackrel{1}{1} \\
\stackrel{0}{0}\end{array}$ & 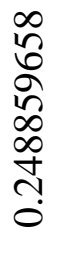 & 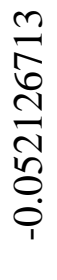 & 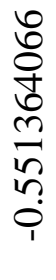 & 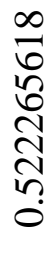 & 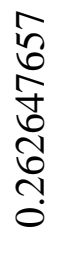 & $\begin{array}{l}0 \\
\infty \\
5 \\
\circ \\
10 \\
8 \\
\infty \\
-1 \\
-1\end{array}$ & 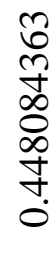 \\
\hline 㒸 & 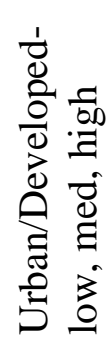 & $\begin{array}{l}\infty \\
0 \\
\infty \\
\infty \\
\sim \\
\infty \\
0 \\
\emptyset \\
\infty \\
0 \\
0\end{array}$ & 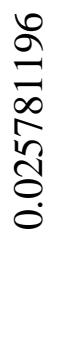 & 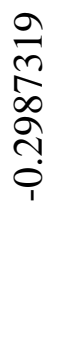 & 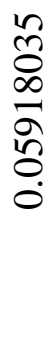 & 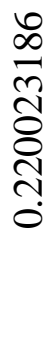 & 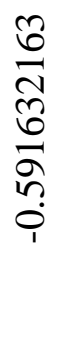 & 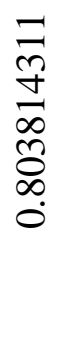 & 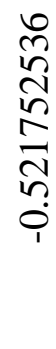 \\
\hline 芫 & 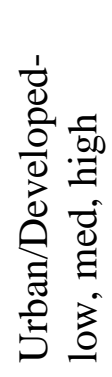 & 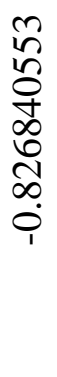 & 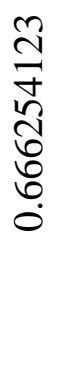 & 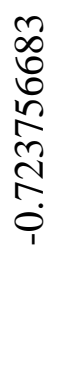 & \begin{tabular}{l}
$\infty$ \\
$\stackrel{2}{N}$ \\
$\hat{N}$ \\
$\stackrel{2}{N}$ \\
\multirow{2}{*}{} \\
$\dot{1}$
\end{tabular} & 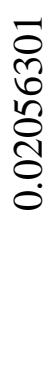 & $\begin{array}{l}m \\
m \\
m \\
0 \\
\text { N } \\
\infty \\
0 \\
+ \\
\end{array}$ & 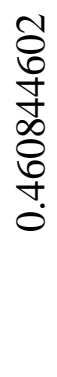 & 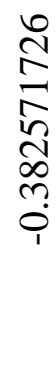 \\
\hline
\end{tabular}




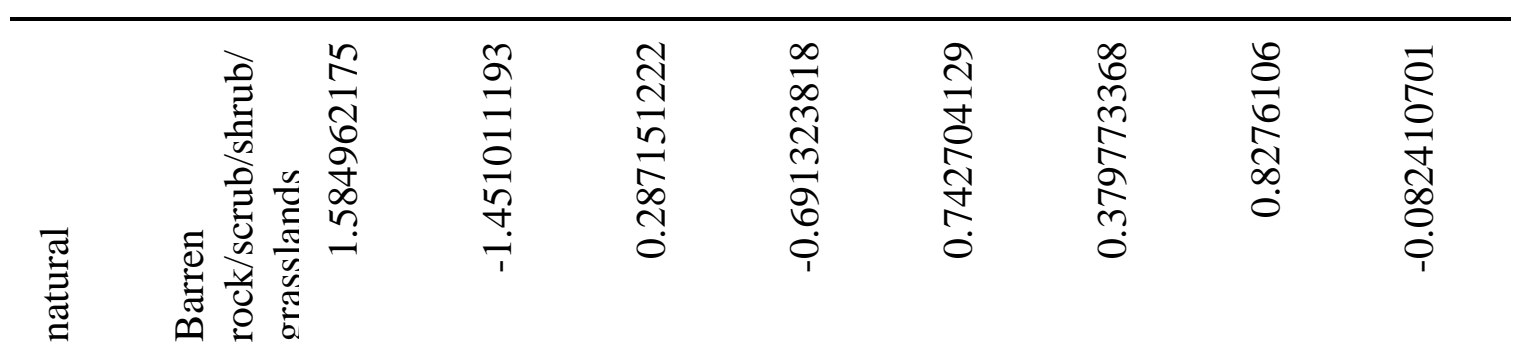

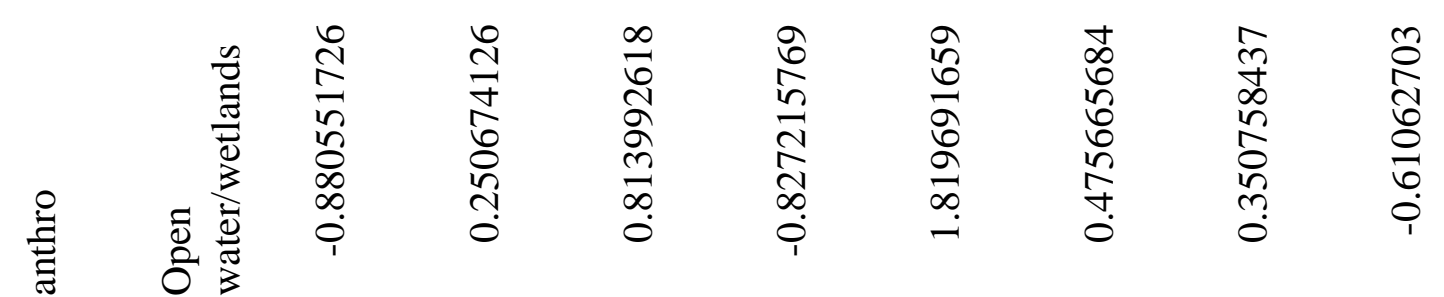

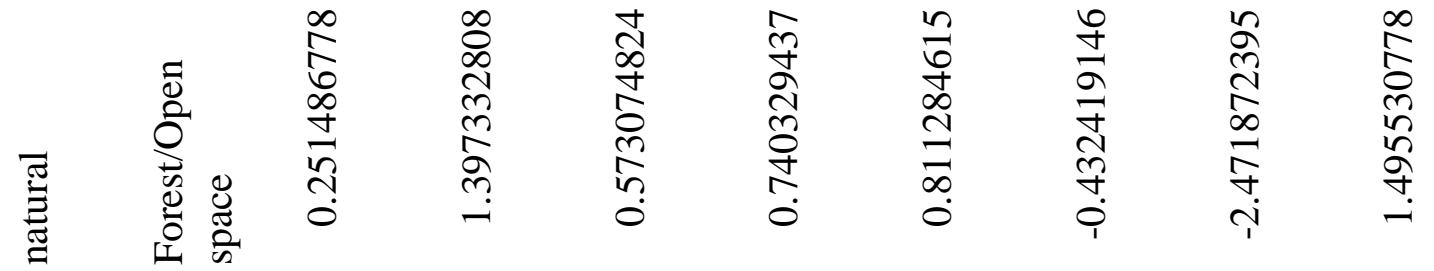

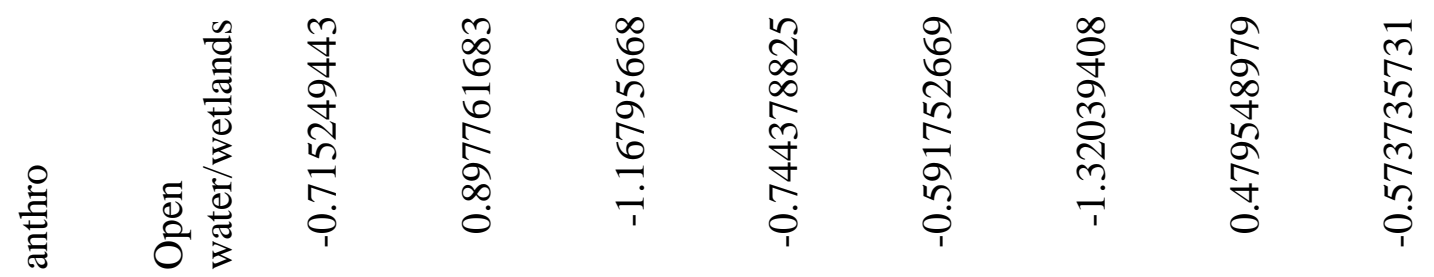

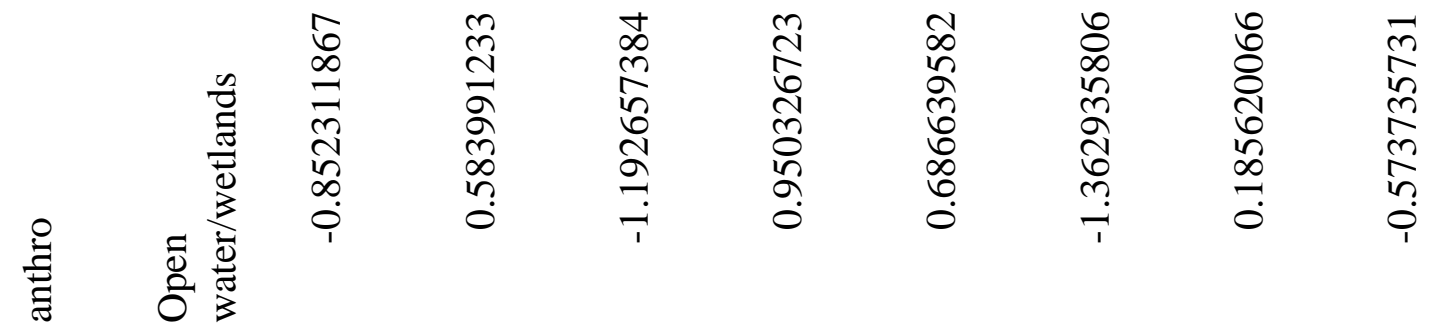

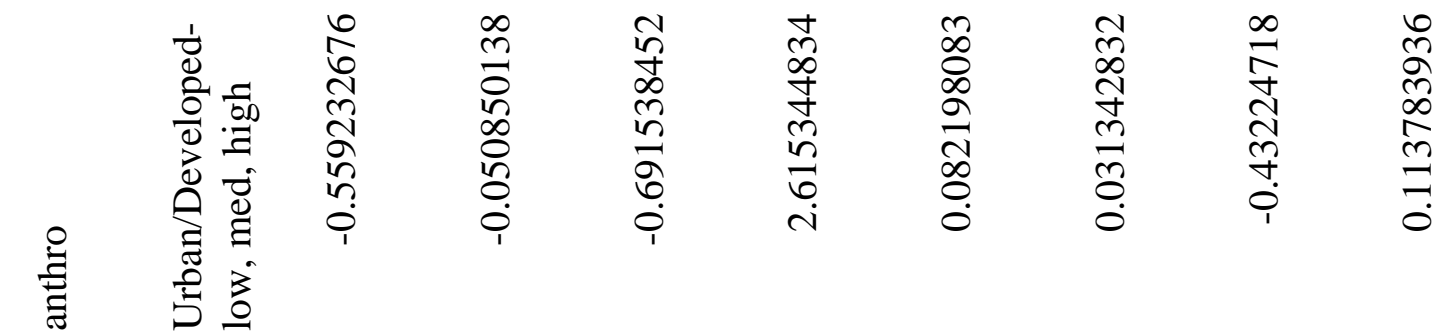




\section{$R$ code for PCA}

APPENDIX C: Continued

(1) library(readxl)

Thesis8VarsExcl2sitesWrldClim <- read_excel("Thesis8VarsExcl2sitesWrldClim.xlsx")

View(Thesis8VarsExcl2sitesWrldClim)

Variables <- Thesis8VarsExcl2sitesWrldClim

Var_Cor $<-$ cor(Variables)

Var_Cor

install.packages("corrplot")

library(corrplot)

corrplot(Var_Cor, type $=$ "upper", order $=$ "hclust", tl.col $=$ "black", tl.cex $=0.5$, tl.srt $=$ 45)

?corrplot

install.packages("FactoMineR")

library(FactoMineR)

\# PCA with function prcomp

pca1 $=$ prcomp $($ Variables, scale. $=$ TRUE $)$

plot(pca1)

\# sqrt of eigenvalues

pca1\$sdev

\#loadings/eigen vectors

head(pca1\$rotation)

\#scores

head(pca1\$x)

pca2 $=$ PCA $($ Variables, graph $=$ FALSE $)$

\#Matrix with eigen values

pca2\$eig

\#correlations between variables and PCs.

pca2\$var\$coord

\#Scores

head(pca2\$ind\$coord)

plot(pca2\$ind\$coord)

abline $(0,0$, col='red')

pca $<-$ prcomp $($ Variables, scale. $=$ TRUE $)$

summary(Variables)

\#plot

plot(pca1, type = "lines")

\#summary

summary(pca)

pca4 $<-$ princomp $($ Variables, cor=TRUE, scores $=$ TRUE $)$

summary(pca4)

plot(pca4, type='lines')

pca4\$scores 


\section{APPENDIX C: Continued}

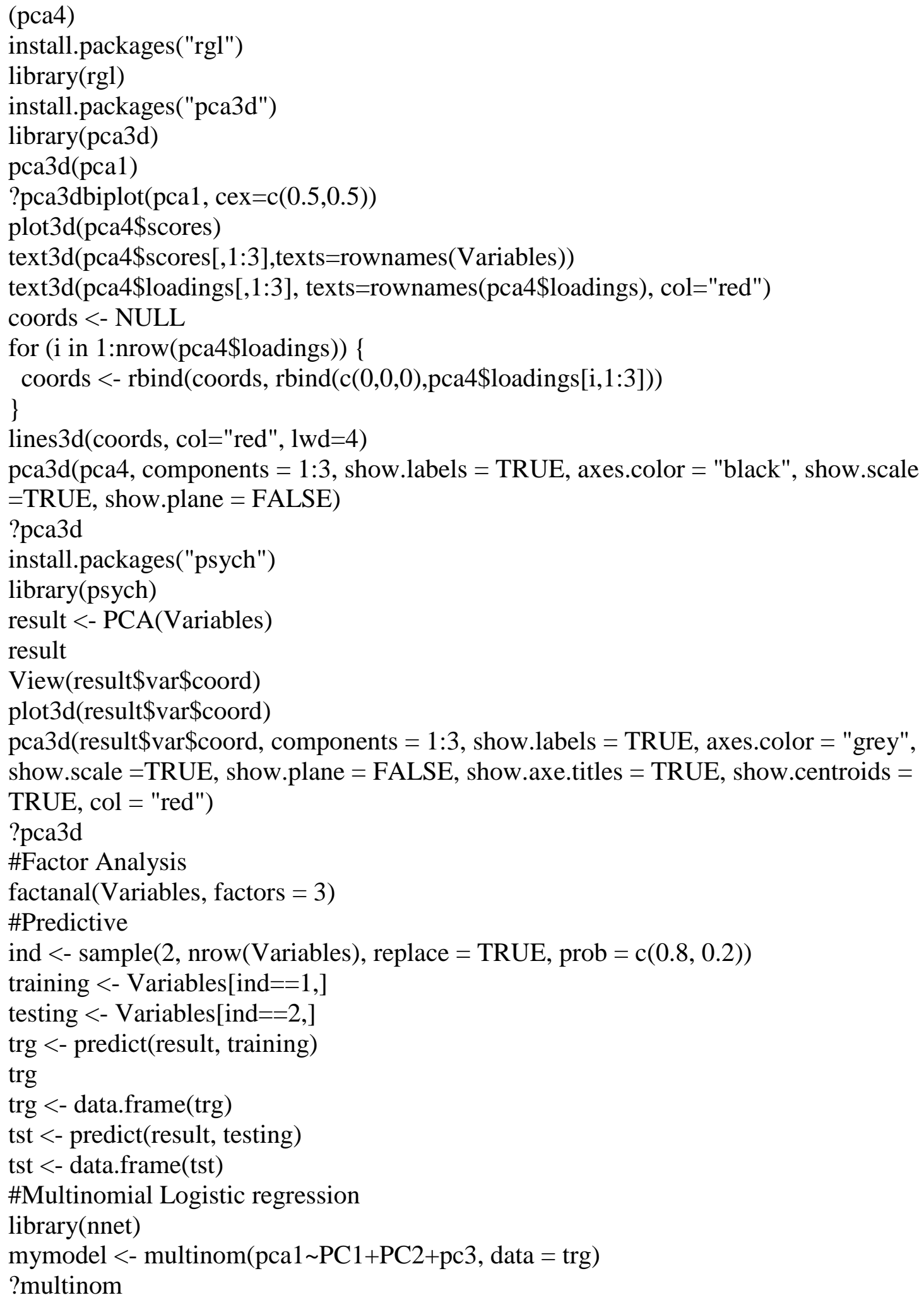


APPENDIX C: Continued

pca1

(2) install.packages('FactoMineR')

library(FactoMineR)

setwd("C:/Users/wsq208lab/Desktop")

dat $=$ read. $\operatorname{csv}($ file.choose () , header $=$ TRUE $)$

res.pca $=$ PCA(dat, scale.unit $=$ TRUE, quali.sup $=\mathrm{c}(1,2), \mathrm{graph}=\mathrm{T})$

summary(res.pca)

barplot(res.pca\$eig[,1], ylab = 'Eigenvalues', names.arg =

paste0('Dim',1:nrow(res.pca\$eig)))

dimdesc(res.pca)

plot(res.pca, habillage $=1$ )

(3) library(readxl)

ThesisVarsForRWrldClimOnly <- read_excel("//130.65.58.1/student/Venu/PVthesis/The sisVarsForRWrldClimOnly.xlsx")

View(ThesisVarsForRWrldClimOnly)

\#check available variables

colnames(my_data)

str(ThesisVarsForRWrldClimOnly)

\#principal component analysis

prin_comp <- prcomp(ThesisVarsForRWrldClimOnly)

names(prin_comp)

\#outputs the mean of variables

prin_comp\$center

\#outputs the standard deviation of variables

prin_comp\$scale

prin_comp\$rotation

dim(prin_comp\$x)

biplot(prin_comp, scale $=0$ )

\#compute standard deviation of each principal component

std_dev <- prin_comp\$sdev

\#compute variance

pr_var $<-$ std_dev $\wedge 2$

\#check variance of the components

pr_var[1:8]

\#proportion of variance explained

prop_varex <- pr_var/sum(pr_var)

prop_varex[1:8]

\#scree plot

plot(prop_varex, xlab = "Principal Component",ylab = "Proportion of Variance Explaine d",type = "b")

biplot(prin_comp, scale $=0$ ) 